\title{
COVID-19: A drug repurposing and biomarker identification by using comprehensive gene-disease associations through protein-protein interaction network analysis
}

\author{
Suresh Kumar* \\ Department of Diagnostic and Allied Health Science, Faculty of Health \& Life Sciences, \\ Management \& Science University, 40100 Shah Alam, Selangor, Malaysia \\ *Corresponding author
}

Suresh Kumar, PhD

Department of Diagnostic and Allied Health Science, Faculty of Health \& Life Sciences Management \& Science University, 40100 Shah Alam, Selangor, Malaysia

Email: sureshkumar@msu.edu.my

\begin{abstract}
COVID-19 (2019-nCoV) is a pandemic disease with an estimated mortality rate of $3.4 \%$ (estimated by the WHO as of March 3, 2020). Until now there is no antiviral drug and vaccine for COVID-19. The current overwhelming situation by COVID-19 patients in hospitals is likely to increase in the next few months. About 15 percent of patients with serious disease in COVID-19 require immediate health services. Rather than waiting for new anti-viral drugs or vaccines that take a few months to years to develop and test, several researchers and public health agencies are attempting to repurpose medicines that are already approved for another similar disease and have proved to be fairly effective. This study aims to identify FDA approved drugs that can be used for drug repurposing and identify biomarkers among high- risk and asymptomatic groups. In this study gene-disease association related to COVID-19 reported mild, severe symptoms and clinical outcomes were determined. The high-risk group was studied related to SARS-CoV-2 viral entry and life cycle by using Disgenet and compared with curated COVID-19 gene data sets from the CTD database. The overlapped gene sets were enriched and the selected genes were constructed for protein-protein interaction networks. Through interactome, key genes were identified for COVID-19 and also for high risk and asymptomatic groups. The key hub genes involved in COVID-19 were VEGFA, TNF, IL-6, CXCL8, IL10, CCL2, IL1B, TLR4, ICAM1, MMP9. The identified key genes were used for drug-gene interaction for drug repurposing. The chloroquine, lenalidomide, pentoxifylline, thalidome, sorafenib, pacitaxel, rapamycin, cortisol, statins were proposed to be probable drug repurposing candidates for the treatment of COVID-19. However, these predicted drug candidates need to be validated through randomized clinical trials. Also, a key gene involved in high risk and the asymptomatic group were identified, which can be used as probable biomarkers for early identification.
\end{abstract}

Keywords: COVID-19, SARS-CoV-2, 2019-nCoV, novel corona virus, drug repurposing, chloroquine, high-risk group, asymptomatic

\section{Introduction:}

Coronaviruses (CoVs) belong to positive-sense RNA viruses that are crown-shaped having club-like spikes on the outer surface (1). There are several types of coronavirus which infect human (2,3). The outbreak which started from December 2019 was found to be novel 
coronavirus (2019-nCoV) also called Severe Acute Respiratory Syndrome (SARS-CoV-2) causes Coronavirus Disease 2019 (COVID-19) (4). Recent findings suggest that clinical \& pathological symptoms caused by COVID-19 resemble SARS, which is caused by the SARS coronavirus (SARS-CoV) $(5,6)$. SARS-CoV and SARS-CoV-2 were both found to be from bat origin(7-11). It is thought that human to human transmission is through an intermediate host (12), while for SARS-CoV it is through civet cat. The SARS-CoV-2 intermediate host is still unknown(13,14). Though some studies predicted intermediate hosts to be though pangolin it is still not proven (15). SARS-CoV-2 and SARS-CoV are also known to infect humans using the same angiotensin-converting enzyme 2 (ACE2) receptor (16). While at the level of the whole genome, SARS-CoV-2 and SARS-CoV were found to be distantly related to sequence identity (79.6\%), but the spike-protein between two viruses was found to be very similar in structure (17).

The Spike protein present in both SARS-CoV and SARS-CoV-2 binds to the host cell through the receptor-binding protein called angiotensin-converting enzyme 2 (ACE2), which is located on the host membrane cell surface. While both SARS-CoV and SARS-CoV-2 bind to the same host cell as ACE2, the SARS-COV-2 binding affinity to ACE2 is significantly higher than that of SARS-CoV. The viral protein responsible for hosting and replication of SARS-CoV-2 entry is identical in structure to SARS-CoV $(18,19)$. To date, there are no antiviral agents and vaccines available for SARS-CoV-2, although the possible antiviral drugs such as remdesivir, chloroquine, hydroxychloroquine, ritonavir/lopinavir with inteferon beta are used as preventive agents for COVID-19 for the treatment of this disease (20-22). Many computational studies are underway to identify potential anti-viral drugs and vaccines $(23,24)$. According to the WHO and CDC, the common symptoms for COVID-19 are runny nose, sore throat, cough, fever, and difficulty in breathing for severe cases. In a recent report from Wuhan hospital based on clinical course and outcome of 107 patients, the clinical progression of COVID-19 is shown as a tri-phasic pattern that involves mild and severe cases of COVID-19 (25). According to the CDC, the severity of cases is mostly for those patients who have high-risk factors like hypertension, diabetes, heart disease, cancer, and lung disease (26).

The popular diagnostic element in the detection of SARS-CoV-2 is in respiratory specimens by next-generation sequencing or RT-PCR methods in real-time. The throat-swab or nasopharyngeal swab specimen collected from patients will be PCR re-examined at every other day. Also performed are regular blood count laboratory review, serum biochemical examination, coagulation profiling, myocardial enzymes, interleukin-6 (IL-6), serum ferritin, and procalcitonin. In addition to that $\mathrm{CT}$ scan or chest, radiographs are used for a routine check for the patients. The patient is considered to recover from COVID-19 if fever is absent for at least 3 days, improvement is noted in lung and chest CT, improvement in respiratory symptoms and negative for SARS-CoV-2 RNA for at least 24 hours from the collected throat-swab specimen of the patient (27-29).

Due to the over-welcoming rush of patients to hospitals, many countries have begun to accept COVID-19 patients only with severe conditions, while mild conditions such as fever and cough have been requested to self-quarantine for 14 days to avoid infecting others. Treatment is desperately needed at around 15 percent of COVID-19 patients with serious illness. Scientists are attempting to repurpose drugs that have already been approved for other similar diseases and have proved to be fairly effective rather than coming up with substances from 
scratch that may take years to develop and test (30-32). In this study, a gene-disease association study was performed for COVID-19 by comparing genes involved in causing symptoms, high-risk factors, and clinical outcomes to identify key genes involved in individual high-risk factors and asymptomatic symptoms for COVID-19.

\section{Methods}

\subsection{Data source \& retrieval:}

DisGeNET(33) is one of the largest and comprehensive databases containing human genedisease associations. All gene-disease association genes were retrieved from the DisGeNet database. This database contains a collection of genes associated with human diseases that contain integrated data from GWAS catalogs and animal models. All the gene-disease association genes were retrieved using the common Human Genome Organisation (HUGO) gene symbol. The gene-disease association was retrieved based on COVID-19 symptoms, clinical outcomes, risk factors, and SARS-CoV infection. Gene Ontology (GO) is the representation of genes with their biological properties. The all gene ontology related to viral entry and viral life cycle was downloaded from the amigo gene ontology database. The human gene-disease association related to COVID-19 was retrieved as follows:

\section{(i) Gene Dataset (GD) construction from Disgenet (GD1)}

1. Cough ( $\mathrm{n}=92$ genes)

2. Fever $(n=874)$

3. Dyspnea/Shortness of breath $(n=187)$

4. Pneumonia $(n=496)$

\section{Risk factors}

5. Heart Disease $(n=324)$

6. Kidney Disease $(n=638)$

7. Lung Disease $(\mathrm{n}=392)$

8. Diabetes $(n=1267)$

9. Hypertension $(\mathrm{n}=1309)$

10. Cancer $(n=1437)$

\section{Clinical Outcomes}

\section{(i) Mild \& Moderate Case}

11. Lymphopenia $(n=136)$

12. Pulmonary infiltrate $(n=18)$

(ii) Severe Case

13.Leukocytosis $(n=32)$ 
14.Neutrophilia $(\mathrm{n}=62)$

15.Sepsis $(\mathrm{n}=528)$

16.Kidney injury $(\mathrm{n}=91)$

17. Coagulopathy $(n=56)$

18.Thrombocytopenia $(n=340)$

19.Multiple organ failure $(n=16)$

\section{SARS-CoV-2 related homology-based gene-disease association}

20. SARS-COV $(n=84)$

21. Viral entry $(n=158)$

22. Viral life cycle $(n=654)$

Asymptomatic gene sets

1. Cough ( $\mathrm{n}=92$ genes)

2. Sore throat ( $\mathrm{n}=6$ genes)

3. Runny nose ( $\mathrm{n}=3$ genes)

4. Diarrhea ( $n=328$ genes)

5 . Headache ( $\mathrm{n}=85$ genes)

(ii) The curated dataset from Comparative Toxicogenomics Database (CTD) (GD2)

The curated dataset related to COVID-19 gene sets were downloaded from CTD (34). These gene sets were collected from the MeSH terms (C000657245) under category respiratory tract disease \& viral disease.

\subsection{Data pre-processing}

All gene-disease association of 22 lists containing related to COVID-19 (GD1) was compared using a multiple comparison tool called multiple list comparator tool available at molbiotools. The tool compares based on pairwise intersections with a full symmetrical matrix based on the Jaccard index. After the comparison, the common gene sets were obtained. All the genes were selected based on the Jaccard index of more than 0.3 from the DisGeNET. All gene sets constructed from disgenet (GD1) were compared with a curated dataset of COVID-19 (GD2) released from the Comparative Toxicogenomics Database containing 473genes. The overlapping gene sets (GD3) were selected for enrichment analysis

\subsection{Gene enrichment analysis}

The overlapping genes selected from gene set (GD3) were enriched for gene ontology mapping using with setting Benjamini and Hochberg with P-value less than 0.05 by using the panther tool(35). 


\subsection{Construction of comprehensive Protein-Protein Interaction (PPI) network}

The Protein-Protein Interaction network was constructed using the STRING database (36) by using selected enriched genes. The STRING is a database containing information on proteinprotein interactions of both known and prediction-based. The selected genes were used to construct a PPI network using the String database with setting to 0.4 and above.

\subsection{Protein-Protein network analysis and identification of key genes}

The PPI network was visualized and analyzed by Cytoscape (37). The key genes were identified by using the cytohubba (38) app available in Cytoscape. It predicts important nodes or hubs in an interactome network by using several topological algorithms. In this study, Maximum Clique Centrality (MCC) was used to identify key/hub genes from the whole network.

\subsection{PPI network construction for high-risk factor group}

Apart from the comprehensive network, the PPI network was constructed only for high-risk factor groups separately to understand the mechanism of disease. For these, four separate networks were constructed for hypertension, diabetes, heart disease, lung disease, kidney disease, and cancer by using SARS-CoV disease-gene association, viral and viral life cycle from gene ontology.

\subsection{PPI network construction for the asymptomatic group (without fever)}

The PPI network was constructed for very mild symptoms like cough, runny nose, diarrhea to understand the mechanism of the asymptomatic group.

\subsection{Drug-gene interaction analysis}

The identified hub genes were predicted for therapeutic target or drug-using drug-gene interaction database (39) (DGIdb2.0; Http: //www.dgidb.org/). The setting was limited to the FDA approved drug database.

\subsection{STITCH drug-gene network construction}

The predicted FDA approved drugs from hub genes through the drug-gene interaction database were used for drug-protein network construction through the STITCH database (40). The drug was prioritized based on a network score of more than 0.9 .

\section{Results \& Discussion}

\subsection{Identification of common genes for COVID-19}

Based on symptoms, clinical outcomes of mild, moderate \& severe cases of COVID-19 related disease, the high-risk factor involved in the COVID-19 severe cases-based diseaseassociated genes were selected for the study. The overall framework of workflow is shown in Figure 1. As the human disease-gene association is lacking for SARS-CoV-2 infection, gene sets related to SARS-CoV was used to relate various symptoms. A clinical outcome of other gene sets of viral entry and viral life cycle was included from the amigo gene ontology database (41). This comprehensive gene set was compared with the pairwise intersection method by using the Jaccard index. These genes selected based on the Jaccard similarity 
score, Jaccard score, disease-gene association score, and disease-disease association score based on the DisgeNet database.

Although these gene-disease associations cannot exclude false-positives, some diseases are better studied than others which can affect the gene-set. Because of this reason, the datasets probably will be noisy and incomplete due to the nature of the curation process. For this reason, the gene sets are selected only from human-data and any gene related to mouse and rat model is discarded. The common genes selected based on the Jaccard similarity score were 1930 (Supplementary Table 1). These genes were compared with the curated list of COVID-19 from the CTD database containing 473 genes (Supplementary Table 2). The non-redundant overlapping genes were selected for gene enrichment (Figure 2).

The common genes are mapped through gene ontology and genes are selected based on the statistical significance of $p$-value less than 0.05 . The selected genes were also compared with the STRING protein-protein interaction database and only the genes which have greater than 0.4 interactions were further selected for network construction. Based on the above criteria, 279 genes were selected as statistically significant enriched genes (Table 1).

\subsection{Protein-Protein interaction network analysis for COVID-19 related genes}

The process by which two or more proteins from a complex through non-covalent bonds is called protein-protein interaction (PPI). The molecular mechanisms of disease or new drug targets can be identified by using PPI network analysis. Moreover, this gene was used to construct Protein-Protein interaction and genes were selected based on the interaction score of more than 0.4 (Figure 3). The PPI network was constructed using the STRING database and analyzed by Cytoscape. The hub genes were identified by using cytohubba using the MCC method (Table 2). This method uses 11 centrality measures to identify the hub genes from the network. The identified top genes function predicted through gene mania webserver revealed that most of the genes were involved in an inflammatory response, cell chemotaxis, cytokine activity, cytokine receptor binding, regulation of inflammatory response and adaptive immune response (Figure 4). The identified top 10 hub genes are as follows:

\section{VEGFA}

This is important for viral infection and its associated pathology(42). Vascular Endothelial Growth Factor promotes SARS-CoV viral entry.

\section{TNF}

Inflammation is a biological reaction resulting in a possible threat. This response may be natural but, under some circumstances, the immune system may attack the normal cells or tissues of the body that cause an abnormal inflammation due to viral entry. TNF- has been identified as a key inflammatory response regulator. TNF signaling responses in the lung to promote viral entry and persistence, pro-inflammatory cytokine tumor necrosis factor-alpha can be readily detected after infection $(43,44)$.

\section{IL-6}

Interleukin 6 (IL-6) is developed in response to induced infection and tissue damage. It is stated that the up-regulation of IL-6 can promote viral survival or alleviation of the disease during viral infections (45). 


\section{CXCL8}

ELR-containing CXC chemokines CXCL8 promotes Neutrophil infiltration. Neutrophil (PMN) infiltration plays a central role in inflammation and is a major cause of tissue damage. This neutrophil infiltration may perform phagocytosis and cause adverse effects of inflammation due to viral associated damage (46).

Interleukin-10 (IL-10) is an immunoregulator to prevent tissue damage, however, the virus evolves to exploit immunoregulatory mechanisms for their survival in the infected host (47).

\section{CCL2}

The CCL2 gene significantly enhances the pathogenesis and replication of viruses (48-50)

\section{ILIB}

IL-1B gene is reported to be mediating acute pulmonary inflammation through inflammation of lung cells during viral infection (51)(52).

\section{TLR4}

The TLR4 Toll-like receptor 4 activation helps to create a defensive immune response but an excessive inflammatory response can lead to damage to the host during viral infection $(53,54)$.

\section{ICAM1}

ICAM-1 (Intercellular Adhesion Molecule 1) gene is stated to play a major role in infectious disease in viral replication modulation and also as a site for the cellular entry of certain viruses. ICAM-1 is caused by interleukin-1 and tumor necrosis factor (TNF) and expressed by the lymphocytes and vascular endothelium $(55,56)$.

\section{MMP9}

MMP9 is developed by a variety of cells in the respiratory tract and has been reported to play a key role during pulmonary viral infection due to immune response modulation. MP9 has anti-Respiratory Syncytial Virus properties that enhance viral clearance, neutrophil recruitment, and loss of MMP9 expression (57). It will be interesting to study the role of MMP9 in innate responses to SARS-CoV-2 infections further.

\subsection{Protein-Protein Interaction network analysis for high-risk factor}

To understand the genes associated during SARS-CoV-2 infection, a separate network was constructed for each risk factor groups like hypertension, diabetes, kidney disease, lung disease, cancer with SARS-CoV diseases associated gene, viral entry, and viral life cycle gene ontology-based gene sets and compared with curated the CTD dataset. The top 10 key genes for hypertension high-risk groups were VEGFA, IL6, TNF, CCL2, MMP9, ALB, IL10, PTGS2, CXCL8, CASP3, and the predicted drugs were paclitaxel, thalidomide, and rapamycin. The top key genes for the diabetic high-risk group were IL, TNF, CXCL8, IL10, CCL2, ICAM1, IFNG, IL2, FN1, CXCR4, and the predicted drugs were plerixafor, quinine, pentoxifylline, and rapamycin. The key genes involved in heart disease high-risk group of COVID-19 were IL6, TNF, CXCL8, CCL2, MAPK1 EGFR, ICAM1, CCL5, CXCR4, AGT, and the predicted drugs were plerixafor, afatinib, gefitinib, paclitaxel, and Cortisol. The key 
genes involved in lung disease high-risk group of COVID-19 were IL6, TNF, CXCL8, IFNG, CCL5, IL10, CCL2, ICAM1, CXCL1, CXCR4, and the predicted drugs were plerixafor. The key genes involved in kidney disease high-risk group of COVID-19 were IL6, TNF, CXCL8, CCL2, IL10, ICAM1 CCL5, FN1, EGFR, CXCR4, and the predicted drugs were plerixafor afatinib bosutinib erlotinib lapatinib vendetanib and pentoxifylline. The key genes involved in cancer high-risk group of COVID-19 were VEGFA, STAT3, IL6, TNF, MAPK3, MAPK1, CASP3, MMP9, PTGS, EGF, and the predicted drugs were gentamicin, hydroxychloroquine sorafenib sulindac thalidomide erlotinib and vandetanib (Table 3).

An inflammatory cytokine is a signaling molecule secreted from helper $\mathrm{T}$ Cells which includes interleukin-1. Tumor necrosis factor-alpha plays an important role in mediating the innate immune response. The excessive production of inflammatory cytokines due to COVID-19 disease contributes to inflammatory disease. Such cytokines include interferons, interleukins, chemokines, colony-stimulating factors, and tumor necrosis factors and lead to coronavirus infection symptoms such as redness, swelling/edema, fever, and pain. The overproduction of pro-inflammatory cytokines can lead to a "cytokine storm," during which inflammation spreads throughout the body through the circulation $(58,59)$. This proinflammatory cytokine has negative adverse effects such as inflammation of the kidney, lungs, and heart, which is the reason for patients to be prone to a high-risk group for COVID19 (60).

\subsection{Protein-Protein Interaction network analysis for asymptotic person}

The protocol is usually practiced at all entry points to assess body temperature for fever and is isolated for laboratory research. However, for people who have no symptoms or very mild, cold-like symptoms like runny nose, cough, and sore throat are overlooked. In general, asymptomatic infections cannot be identified until they are confirmed by RT-PCR. Yet it is treated as a silent carrier. Finding genes related to asymptomatic showing just sore throat, cough, runny nose, headache without fever will improve understanding of COVID-19 transmission and spectrum of the disease it causes and it will provide insight into the pandemic cause. The protein-protein network was constructed with symptoms like cough, runny nose, sore throat along with SARS-CoV, viral entry and viral life cycle gene sets and compared with CTD curated COVID-19 gene data set. The key genes involved in an asymptomatic group of COVID-19 predicted genes are IL6, TNF, CXCL8 IL1B, IL10, CCL2, ICAM1, IL2, STAT3, and CCL5. These IL1B and STAT3 can only be found in the asymptomatic group when compared to other groups. Upregulation of STAT5 dimers gene expression has been observed for inflammation-related genes. Signal transducer and transcription activator 3 (STAT3) is a central regulator of many physiological functions, including immune response. Interleukin 1 beta (IL-1 $\beta$ ) also known as leukocytic pyrogen is a cytokine protein encoded by the IL1B gene in humans. This cytokine is an essential mediator of inflammatory reactions and is involved in several cellular activities, including cell proliferation, differentiation, and apoptosis. These genes can be used as biomarkers to identify COVID-19 in the asymptomatic group (Table 3).

\subsection{Drug-gene interaction analysis of COVID-19}

Based on the drug-gene interaction database (DGIdb2.0), the identified FDA approved drugs with the gene were used for STITCH prediction for each drug-gene association (Figure 5- 
14). The drugs were selected based on the network interaction score above 0.9 as follows (Table 2):

\section{TNF}

Chloroquine (0.969)

Chloroquine is a medication used to prevent and treat malaria (61) and is suggested for COVID-19 treatment. Chloroquine has antiviral effects that work by increasing endosomal $\mathrm{pH}$ resulting in impaired virus/cell fusion that requires a low $\mathrm{pH}$. The presence of nitrogens in chloroquine and the number of related isoquinoline and quinoline drug family members prevent the endosome from acidifying and thereby disrupt viral replication. When more nitrogens are added, either by making extra branches of ionizable nitrogens or by lengthening one of the chains by adding extra carbons and other nitrogens around it which can have an even greater effect.

\section{lenalidomide (0.940)}

Over the past ten years, lenalidomide has been used widely to treat both inflammatory conditions and cancers.

Penicillin (0.933)

Penicillin is a group of antibiotics. The combination of antibiotics with an anti-viral drug is proved effective in controlling viral replication.

Pentoxifylline (0.990)

This is used as a drug to treat muscle pain in people with peripheral artery disease. Studies have demonstrated a reduction in the risk of hepatorenal syndrome. Pentoxifylline, a phosphodiesterase inhibitor potently suppresses cytokine production as a neonatal antiinflammatory agent. It is reported to be more effective at improving blood vessel function and reducing inflammation than antiretroviral medications alone in people infected with $\operatorname{HIV}(62,63)$.

\section{Thalidome (0.980)}

Thalidome used for cancer diagnosis is also used for treating a variety of HIV-related conditions(64).

\section{VEGFA}

\section{Sorafenib (0.909)}

This is used for treating cancer of the kidneys, liver, and lung (65). It is reported sorafenib inhibited replication of New World alphaviruses and two Old World alphaviruses, Sindbis virus, and chikungunya virus, leading to a reduction in viral protein production and overall viral replication (66).

\section{IL8}

Paclitaxel (0.947) is used to treat several types of cancer and reported to have anti-viral activity (67). 


\section{IL10}

Rapamycin (0.985)-Rapamycin, a powerful mTOR inhibitor, has proven effective in the treatment of some diseases. Immunomodulatory drug rapamycin (RAPA) possesses anti-HIV properties and can be a valuable medication that should be used for viral infection prevention and treatment(68).

\section{IL1B}

Cortisol (0.958)

Cortisol medication used to treat conditions arising from the B-Cell mediated antibody response due to overactivation and prevents the cause of inflammation by limiting the release of inflammatory substances. Corticosteroids are used in the treatment of severe acute respiratory syndrome (SARS-CoV) and it may suppress the "cytokine storm"(69).

\section{ICAM1}

Statins (0.987)

They are the most common cholesterol-lowering drugs. It is hypothesized to prevent cardiovascular disease through modulation of inflammatory response. Lipophilic statins like fluvastatin are efficient to use anti-zika virus drugs are reported (70). Statins have lowered the occurrence of severe infections or have improved health results for those diagnosed with viral or bacterial infections, including pneumonia. Statins modulate the antiviral response of the first line of protection against invading pathogens in human bronchial and epithelial cells (71).

\section{Conclusion and limitation of the study}

In this study, by using gene-disease association, genes related to COVID-19 symptoms, clinical outcomes, and risk factors were studied using the network-based methodology for identification of drug repurposing and also network analysis for the high-risk group and asymptomatic to identify biomarkers. Based on this analysis, drug targets for prioritized and genes were identified as biomarkers. These results were validated by literature data, but this study has several limitations. All predicted drugs must be validated either through randomized clinical trials or through experimental assays before being used in patients. The network was constructed based on the gene-disease associations and from the curated data set from the disgenet and CTD database, which were based on literature mining. However, it is noted during the writing of this manuscript that the network analysis of this study reported chloroquine as already used in the treatment of COVID-19.

\section{Acknowledgment}

The support of Management and Science University, Malaysia is acknowledged

\section{Conflict of interest: None}

Funding: No funding for this research 


\section{References:}

1. Sci AS-IJCRM, 2020 undefined. Coronavirus: A mini-review. academia.edu [Internet]. [cited $2020 \quad$ Mar 24]; Available from: http://www.academia.edu/download/62221295/corona_virus.pdf

2. Perlman S. Another Decade, Another Coronavirus. New England Journal of Medicine [Internet]. 2020 [cited 2020 Feb 2];NEJMe2001126. Available from: http://www.nejm.org/doi/10.1056/NEJMe2001126

3. Lim YX, Ng YL, Tam JP, Liu DX. Human Coronaviruses: A Review of Virus-Host Interactions. Wiley Online Library [Internet]. [cited 2020 Mar 24]; Available from: www.mdpi.com/journal/diseases

4. Andersen K, Rambaut A, Lipkin W, Medicine EH-N, 2020 undefined. The proximal origin of SARS-CoV-2. nature.com [Internet]. [cited 2020 Mar 24]; Available from: https://www.nature.com/articles/s41591-020-0820-9

5. Corman VM, Landt O, Kaiser M, Molenkamp R, Meijer A, Chu DK, et al. Detection of 2019 novel coronavirus $(2019-\mathrm{nCoV})$ by real-time RT-PCR. Eurosurveillance [Internet]. 2020 [cited 2020 Feb 2];25(3):2000045. Available from: https://www.eurosurveillance.org/content/10.2807/1560-7917.ES.2020.25.3.2000045

6. Zhu W, Shen X. An Overall Picture of SARS Coronavirus (SARS-CoV) GenomeEncoded Major Proteins: Structures, Functions and Drug Development. 2006 [cited 2020 Feb 2]; Available from: http://www.who.int/csr/sars/country/

7. Poon LLM, Chu DKW, Chan KH, Wong OK, Ellis TM, Leung YHC, et al. Identification of a Novel Coronavirus in Bats. JOURNAL OF VIROLOGY [Internet]. 2005 [cited 2020 Feb 2];79(4):2001-9. Available from: http://jvi.asm.org/

8. $\mathrm{Hu}$ B, Ge X, Wang LF, Shi Z. Bat origin of human coronaviruses Coronaviruses: Emerging and re-emerging pathogens in humans and animals Susanna Lau Positivestrand RNA viruses. Vol. 12, Virology Journal. BioMed Central Ltd.; 2015.

9. $\mathrm{Hu} \mathrm{B}, \mathrm{Ge} \mathrm{X}$, Wang L, journal ZS-V, 2015 undefined. Bat origin of human coronaviruses. virologyj.biomedcentral.com [Internet]. [cited 2020 Feb 2]; Available from: https://virologyj.biomedcentral.com/articles/10.1186/s12985-015-0422-1

10. Ge X, Li J, Yang X, Chmura A, Zhu G, Nature JE-, et al. Isolation and characterization of a bat SARS-like coronavirus that uses the ACE2 receptor. nature.com [Internet]. [cited 2020 Feb 2]; Available from: https://www.nature.com/articles/nature12711

11. Banerjee A, Kulcsar K, Misra V, Frieman M, Mossman K, contributed equally K. viruses Bats and Coronaviruses. mdpi.com [Internet]. [cited 2020 Mar 24]; Available from: www.mdpi.com/journal/viruses

12. Parry J. China coronavirus: cases surge as official admits human to human transmission. 2020 [cited 2020 Feb 2]; Available from: https://www.bmj.com/content/368/bmj.m236.long

13. Pillaiyar T, Manickam M, Namasivayam V, Hayashi Y, Jung SH. An overview of severe acute respiratory syndrome-coronavirus (SARS-CoV) 3CL protease inhibitors: Peptidomimetics and small molecule chemotherapy. Vol. 59, Journal of Medicinal Chemistry. American Chemical Society; 2016. p. 6595-628. 
14. On the origin and continuing evolution of SARS-CoV-2 | National Science Review | Oxford Academic [Internet]. [cited 2020 Mar 24]. Available from: https://academic.oup.com/nsr/advance-article/doi/10.1093/nsr/nwaa036/5775463

15. Zhang T, Wu Q, Zhang Z. Probable pangolin origin of SARS-CoV-2 associated with the COVID-19 outbreak. CelPress. 2020;

16. Liu Z, Xiao X, Wei X, Li J, Yang J, Tan H, et al. Composition and divergence of coronavirus spike proteins and host ACE2 receptors predict potential intermediate hosts of SARS-CoV-2. Journal of Medical Virology. 2020 Mar 11;

17. Li F. Structure, Function, and Evolution of Coronavirus Spike Proteins. Annual Review of Virology. 2016;

18. Li F, Li W, Farzan M, Harrison SC. Structural biology: Structure of SARS coronavirus spike receptor-binding domain complexed with receptor. Science. 2005;

19. Belouzard S, Millet JK, Licitra BN, Whittaker GR. Mechanisms of coronavirus cell entry mediated by the viral spike protein. Viruses. 2012.

20. Gao J, Tian Z, Yang X. Breakthrough: Chloroquine phosphate has shown apparent efficacy in treatment of COVID-19 associated pneumonia in clinical studies. jstage.jst.go.jp [Internet]. [cited 2020 Mar 24]; Available from: www.biosciencetrends.com

21. Yao T, Qian J, Zhu W, Wang Y, Wang G. A systematic review of lopinavir therapy for SARS coronavirus and MERS coronavirus-A possible reference for coronavirus disease-19 treatment option. Journal of Medical Virology. 2020 Mar 12;

22. Li G, Leuven KU. Therapeutic options for the 2019 novel coronavirus (2019-nCoV). 2020 [cited 2020 Mar 24]; Available from: https://doi.org/10.1038/s41422-020-0282-0

23. Kumar S. Drug and Vaccine Design against Novel Coronavirus (2019-nCoV) Spike Protein through Computational Approach. Preprints (www.preprints.org) [Internet]. 2020;(February). Available from: https://www.preprints.org/manuscript/202002.0071/v1

24. Dhama K, Sharun K, Tiwari R, Dadar M, Malik YS, Singh KP, et al. COVID-19, an emerging coronavirus infection: advances and prospects in designing and developing vaccines, immunotherapeutics, and therapeutics. Human vaccines \& immunotherapeutics [Internet]. 2020 Mar 18 [cited 2020 Mar 24];1-7. Available from: http://www.ncbi.nlm.nih.gov/pubmed/32186952

25. Hu B. Clinical course and outcome of novel coronavirus COVID-19 infection in 107 patients discharged from the Wuhan hospital. Preprint. 2020;1-23.

26. Zhou F, Yu T, Du R, Fan G, Liu Y, Liu Z, et al. Clinical course and risk factors for mortality of adult inpatients with COVID-19 in Wuhan, China: a retrospective cohort study. Elsevier [Internet]. [cited 2020 Mar 24]; Available from: https://www.sciencedirect.com/science/article/pii/S0140673620305663

27. Al-Tawfiq J, Hospital ZM-J of, 2020 undefined. Diagnosis of SARS-CoV-2 Infection based on CT scan vs. RT-PCR: Reflecting on Experience from MERS-CoV. journalofhospitalinfection.com [Internet]. [cited 2020 Mar 24]; Available from: https://www.journalofhospitalinfection.com/article/S0195-6701(20)30100-6/abstract 
28. Liu X, Wang Y, Kang H, Tong Z. Combination of RT-qPCR Testing and Clinical Features For Diagnosis of COVID-19 facilitates management of SARS-CoV-2 Outbreak. Wiley Online Library [Internet]. 2020 [cited 2020 Mar 24]; Available from: https://onlinelibrary.wiley.com/doi/abs/10.1002/jmv.25721

29. Guo L, Huang Y, Tu M, Wang S, Chen S, Long W. Confusion and Thinking on the Diagnosis and Treatment of Patients with Negative RT-PCR Results for SARS-CoV-2. 2020 [cited 2020 Mar 24]; Available from: https://papers.ssrn.com/sol3/papers.cfm?abstract_id=3551322

30. Talevi A, Bellera C. Challenges and opportunities with drug repurposing: finding strategies to find alternative uses of therapeutics. 2020 [cited 2020 Mar 24]; Available from: https://www.tandfonline.com/doi/full/10.1080/17460441.2020.1704729

31. Pushpakom S, Iorio F, Eyers P, ... KE-N reviews D, 2019 undefined. Drug repurposing: progress, challenges and recommendations. nature.com [Internet]. [cited 2020 Mar 24]; Available from: https://www.nature.com/nrd/journal/v18/n1/full/nrd.2018.168.html

32. Lötsch J, Kringel D. Use of Computational Functional Genomics in Drug Discovery and Repurposing for Analgesic Indications. Clinical Pharmacology and Therapeutics. 2018 Jun 1;103(6):975-8.

33. Piñero J, Ramírez-Anguita JM, Saüch-Pitarch J, Ronzano F, Centeno E, Sanz F, et al. The DisGeNET knowledge platform for disease genomics: 2019 update. Nucleic Acids Research. 2019 Nov;

34. Davis A, Grondin C, ... RJ-N acids, 2019 undefined. The comparative toxicogenomics database: update 2019. academic.oup.com [Internet]. [cited $2020 \mathrm{Mar}$ 24]; Available from: https://academic.oup.com/nar/articleabstract/47/D1/D948/5106145

35. Mi H, Muruganujan A, Ebert D, ... XH-N acids, 2019 undefined. PANTHER version 14: more genomes, a new PANTHER GO-slim and improvements in enrichment analysis tools. academic.oup.com [Internet]. [cited 2020 Mar 24]; Available from: https://academic.oup.com/nar/article-abstract/47/D1/D419/5165346

36. Szklarczyk D, Gable AL, Lyon D, Junge A, Wyder S, Huerta-Cepas J, et al. STRING v11: Protein-protein association networks with increased coverage, supporting functional discovery in genome-wide experimental datasets. Nucleic Acids Research. 2019 Jan;47(D1):D607-13.

37. Shannon P, Markiel A, Ozier O, Baliga NS, Wang JT, Ramage D, et al. Cytoscape: A software Environment for integrated models of biomolecular interaction networks. Genome Research. 2003 Nov;13(11):2498-504.

38. Chin $\mathrm{CH}$, Chen $\mathrm{SH}, \mathrm{Wu} \mathrm{HH}$, Ho CW, Ko MT, Lin CY. cytoHubba: Identifying hub objects and sub-networks from complex interactome. BMC Systems Biology. 2014 Dec;8(4).

39. Griffith M, Griffith OL, Coffman AC, Weible J V., Mcmichael JF, Spies NC, et al. DGIdb: Mining the druggable genome. Nature Methods. 2013 Dec;10(12):1209-10.

40. Szklarczyk D, Santos A, ... C von M-N acids, 2016 undefined. STITCH 5: augmenting protein-chemical interaction networks with tissue and affinity data. 
academic.oup.com [Internet]. [cited 2020 Mar 24]; Available from: https://academic.oup.com/nar/article-abstract/44/D1/D380/2503089

41. Foulger RE, Osumi-Sutherland D, McIntosh BK, Hulo C, Masson P, Poux S, et al. Representing virus-host interactions and other multi-organism processes in the Gene Ontology. BMC Microbiology. 2015 Jul 28;15(1).

42. Hicklin DJ, Ellis LM. Role of the vascular endothelial growth factor pathway in tumor growth and angiogenesis. Journal of clinical oncology: official journal of the American Society of Clinical Oncology [Internet]. 2005 Feb 10 [cited 2020 Mar 24];23(5):1011-27. Available from: http://www.ncbi.nlm.nih.gov/pubmed/15585754

43. Herbein G, O'Brien WA. Tumor necrosis factor (TNF)- $\alpha$ and TNF receptors in viral pathogenesis. Vol. 223, Proceedings of the Society for Experimental Biology and Medicine. 2000. p. 241-57.

44. Haga S, Yamamoto N, Nakai-Murakami C, Osawa Y, Tokunaga K, Sata T, et al. Modulation of TNF- $\alpha$-converting enzyme by the spike protein of SARS-CoV and ACE2 induces TNF- $\alpha$ production and facilitates viral entry. Proceedings of the National Academy of Sciences of the United States of America. 2008 Jun 3;105(22):7809-14.

45. Frei K, Malipiero U V., Leist TP, Zinkernagel RM, Schwab ME, Fontana A. On the cellular source and function of interleukin 6 produced in the central nervous system in viral diseases. European Journal of Immunology [Internet]. 1989 Apr 1 [cited 2020 Mar 24];19(4):689-94. Available from: http://doi.wiley.com/10.1002/eji.1830190418

46. Mukaida N. Pathophysiological roles of interleukin-8/CXCL8 in pulmonary diseases. Vol. 284, American Journal of Physiology - Lung Cellular and Molecular Physiology. American Physiological SocietyBethesda, MD ; 2003.

47. Brooks DG, Trifilo MJ, Edelmann KH, Teyton L, McGavern DB, Oldstone MBA. Interleukin-10 determines viral clearance or persistence in vivo. Nature Medicine. 2006 Nov 15;12(11):1301-9.

48. Sabbatucci M, Covino AA, Purificato C, Mallano A, Federico M, Lu J, et al. Endogenous CCL2 neutralization restricts HIV-1 replication in primary human macrophages by inhibiting viral DNA accumulation. Retrovirology. 2015 Jan 22;12(1).

49. Ansari AW, Heiken H, Meyer-Olson D, Schmidt RE. CCL2: A potential prognostic marker and target of anti-inflammatory strategy in HIV/AIDS pathogenesis. European Journal of Immunology. 2011 Dec;41(12):3412-8.

50. Angela Covino D, Sabbatucci M, Fantuzzi L. The CCL2/CCR2 Axis in the Pathogenesis of HIV-1 Infection: A New Cellular Target for Therapy? Current Drug Targets. 2015 Dec 22;17(1):76-110.

51. Kim KS, Jung H, Shin IK, Choi BR, Kim DH. Induction of interleukin-1 beta (IL-1 $\beta$ ) is a critical component of lung inflammation during influenza A (H1N1) virus infection. Journal of Medical Virology. 2015 Jul 1;87(7):1104-12.

52. Liu Y, Li S, Zhang G, Nie G, Meng Z, Mao D, et al. Genetic variants in IL1A and IL1B contribute to the susceptibility to 2009 pandemic H1N1 influenza A virus. BMC Immunology. 2013 Aug 8;14(1):37.

53. Olejnik J, Hume AJ, Mühlberger E. Toll-like receptor 4 in acute viral infection: Too 
much of a good thing. Vol. 14, PLoS Pathogens. Public Library of Science; 2018.

54. Okumura A, Pitha PM, Yoshimura A, Harty RN. Interaction between Ebola Virus Glycoprotein and Host Toll-Like Receptor 4 Leads to Induction of Proinflammatory Cytokines and SOCS1. Journal of Virology. 2010 Jan 1;84(1):27-33.

55. Othumpangat S, Noti JD, McMillen CM, Beezhold DH. ICAM-1 Regulates the survival of influenza virus in lung epithelial cells during the early stages of infection. Virology. 2016 Jan 1;487:85-94.

56. BOUNOU S, GIGUÈRE J-F, CANTIN R, GILBERT C, IMBEAULT M, MARTIN G, et al. The importance of virus-associated host ICAM-1 in human immunodeficiency virus type 1 dissemination depends on the cellular context. The FASEB Journal. 2004 Aug 18;18(11):1294-6.

57. Dabo AJ, Cummins N, Eden E, Geraghty P. Matrix metalloproteinase 9 exerts antiviral activity against respiratory syncytial virus. PLoS ONE. 2015 Aug 18;10(8).

58. Tisoncik JR, Korth MJ, Simmons CP, Farrar J, Martin TR, Katze MG. Into the Eye of the Cytokine Storm. Microbiology and Molecular Biology Reviews. 2012 Mar $1 ; 76(1): 16-32$.

59. D́elia R V., Harrison K, Oyston PC, Lukaszewski RA, Clark GC. Targeting the "Cytokine Storm" for Therapeutic Benefit. Vol. 20, Clinical and Vaccine Immunology. American Society for Microbiology; 2013. p. 319-27.

60. Proinflammatory Cytokine Responses in Extra-Respiratory Tissues During Severe Influenza - PubMed [Internet]. [cited 2020 Mar 25]. Available from: https://pubmed.ncbi.nlm.nih.gov/28973159/

61. Aguiar ACC, Murce E, Cortopassi WA, Pimentel AS, Almeida MMFS, Barros DCS, et al. Chloroquine analogs as antimalarial candidates with potent in vitro and in vivo activity. International Journal for Parasitology: Drugs and Drug Resistance. 2018 Dec $1 ; 8(3): 459-64$.

62. Gupta SK, Dubé MP, Stein JH, Clauss MA, Liu Z. A pilot trial of pentoxifylline on endothelial function and inflammation in HIV-infected patients initiating antiretroviral therapy. Vol. 30, AIDS. Lippincott Williams and Wilkins; 2016. p. 2139-42.

63. Fazely F, Dezube B, Allen-Ryan J, Pardee A, Ruprecht R. Pentoxifylline (Trental) decreases the replication of the human immunodeficiency virus type 1 in human peripheral blood mononuclear cells and in cultured T cells [see comments]. Blood [Internet]. 1991 Apr 15 [cited 2020 Mar 25];77(8):1653-6. Available from: https://ashpublications.org/blood/article/77/8/1653/168632/Pentoxifylline-Trentaldecreases-the-replication

64. Vignesh R, Shankar EM. Thalidomide as a Potential HIV Latency Reversal Agent: Is It the Right Time to Forget the Ancestral Sins? Vol. 24, EBioMedicine. Elsevier B.V.; 2017. p. 20-1.

65. Cheong J, Cho H, Kim J, Kim S, Kyaw Y, Win A. Sorafenib suppresses hepatitis B virus gene expression via inhibiting JNK pathway. Hepatoma Research. 2015;1(2):97.

66. Lundberg L, Brahms A, Hooper I, Carey B, Lin SC, Dahal B, et al. Repurposed FDAApproved drug sorafenib reduces replication of Venezuelan equine encephalitis virus and other alphaviruses. Antiviral Research. 2018 Sep 1;157:57-67. 
67. Ryang J, Yan Y, Song Y, Liu F, Ng TB. Anti-HIV, antitumor and immunomodulatory activities of paclitaxel from fermentation broth using molecular imprinting technique. AMB Express [Internet]. 2019 Dec 1 [cited 2020 Mar 25];9(1):194. Available from: https://amb-express.springeropen.com/articles/10.1186/s13568-019-0915-1

68. Shi G, Ozog S, Torbett BE, Compton AA. MTOR inhibitors lower an intrinsic barrier to virus infection mediated by IFITM3. Proceedings of the National Academy of Sciences of the United States of America. 2018 Oct 23;115(43):E10069-78.

69. Yu WC, Hui DSC, Chan-Yeung M. Antiviral agents and corticosteroids in the treatment of severe acute respiratory syndrome (SARS). Vol. 59, Thorax. BMJ Publishing Group Ltd; 2004. p. 643-5.

70. Españo E, Nam JH, Song EJ, Song D, Lee CK, Kim JK. Lipophilic statins inhibit Zika virus production in Vero cells. Scientific Reports. 2019 Dec 1;9(1):1-11.

71. Boyd AR, Mortensen EM. Are statins beneficial for viral pneumonia? Vol. 41, European Respiratory Journal. European Respiratory Society; 2013. p. 1010-1. 


\section{Figure legends}

Figure 1: Overall framework for prioritizing COVID-19 key genes using network-based approaches. The workflow contains 5 steps including (A) retrieving COVID-19 disease-gene list from DisgeNet and The Comparative Toxicogenomics Database (CTD) -Curated COVID-19 gene-sets (B) The overlapping common genes enriched for gene ontology with a p-value less than 0.05 (C) Protein-Protein interaction of statistically significant genes with setting greater than 0.4 (D) Identification of key genes using Cytohubba (E) Identification drugs from the druggable genome by using DGIdb and STITCH.

Figure 2: Gene ontology (BO) analysis of COVID-19 genes for selection of statistically significant genes using gene enrichment analysis

Figure 3: Protein-protein interaction of all 279 disease-gene association of COVID-19 showing 261 nodes and 2542 edges with average node degee 19.5by using STRING database with setting greater than 0.4

Figure 4: The predicted function of top 10 hub disease-gene network association of COVID19 using gene mania

Figure 5: Drug-gene network of TNF and its druggable FDA approved drugs. The network shows cholorquine, hydrocholorquine and penicillin and other related drugs to the TNF network.

Figure 6: Drug-gene network of VEGFA using STITCH database

Figure 7: Drug-gene network of IL6 using STITCH database

Figure 8: Drug-gene network of IL8 (CCL8) using STITCH database

Figure 9: Drug-gene network of IL10

Figure 10: Drug-gene network of CCL2

Figure 11: Drug-gene network of IL1B

Figure 12: Drug-gene network of TLR4

Figure 13: Drug-gene network of ICAM1

Figure 14: Drug-gene interaction of MMP9

Figure 15 : PPI network of (A) Cancer (B) Diabetes (C) Heart Disease (D) Hypertension (E) Kidney Disease (F)Lung Disease (G) Asymptomatic

\section{Table legends}

Table 1 : The 279 enriched gene based on gene ontology (GO Slim) - Biological process selected based on criteria P-Value less than 0.05

Table 2: Identified top 10 druggable genes, showing gene-disease association and predicted of STITCH \& DGIdb2.0 of FDA drugs from drug-gene association

Table 3: Top 10 key genes of high risk with predicted FDA approved drug and asymptomatic group identified from Protein-Protein interaction network by using Cytohubba 


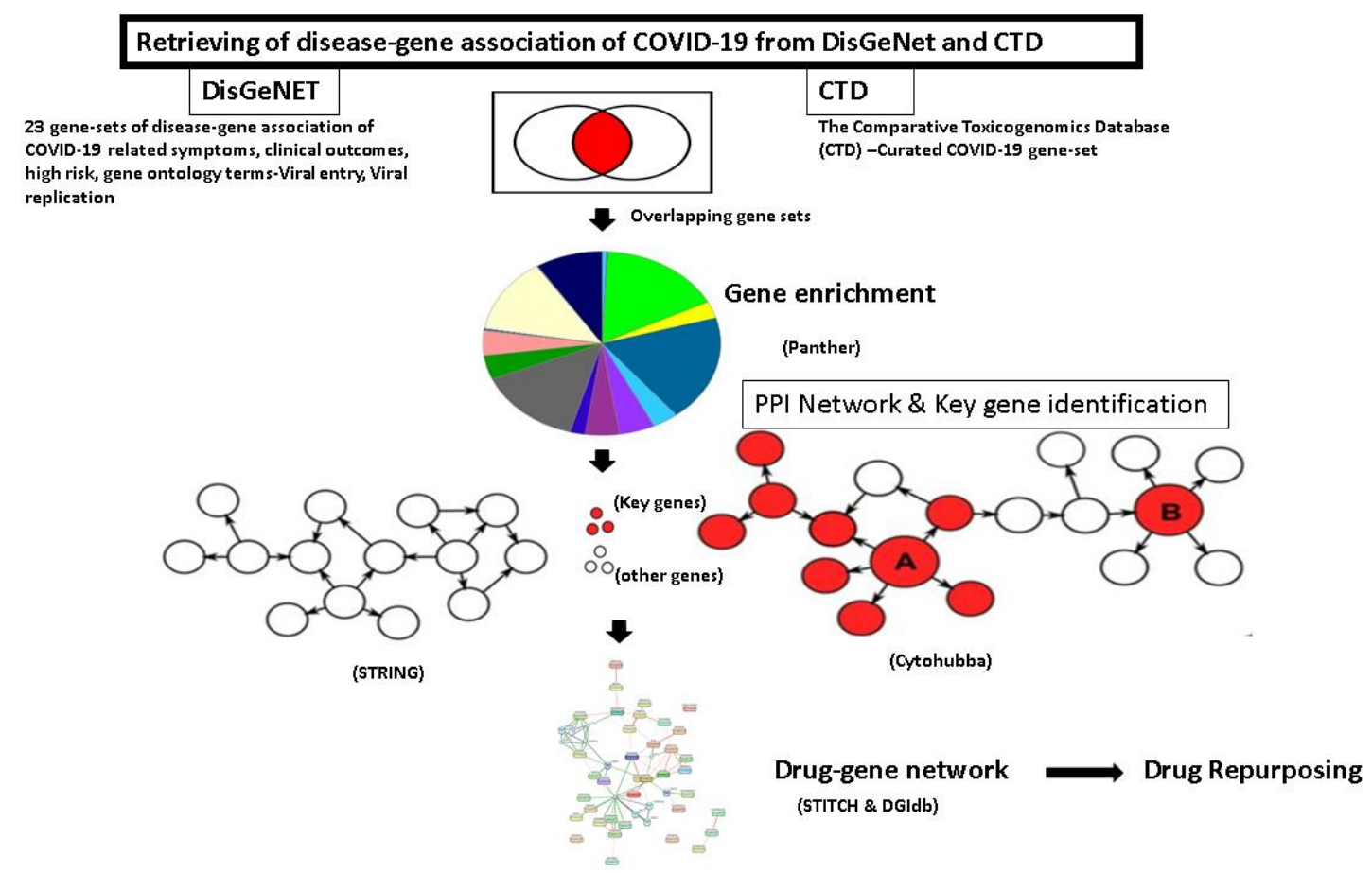

Figure 1: Overall framework for prioritizing COVID-19 key genes using network-based approaches. The workflow contains 5 steps including (A) retrieving COVID-19 disease-gene list from DisgeNet and The Comparative Toxicogenomics Database (CTD) -Curated COVID-19 gene-sets (B) The overlapping common genes enriched for gene ontology with a p-value less than 0.05 (C) Protein-Protein interaction of statistically significant genes with setting greater than 0.4 (D) Identification of key genes using Cytohubba (E) Identification drugs from the druggable genome by using DGIdb and STITCH

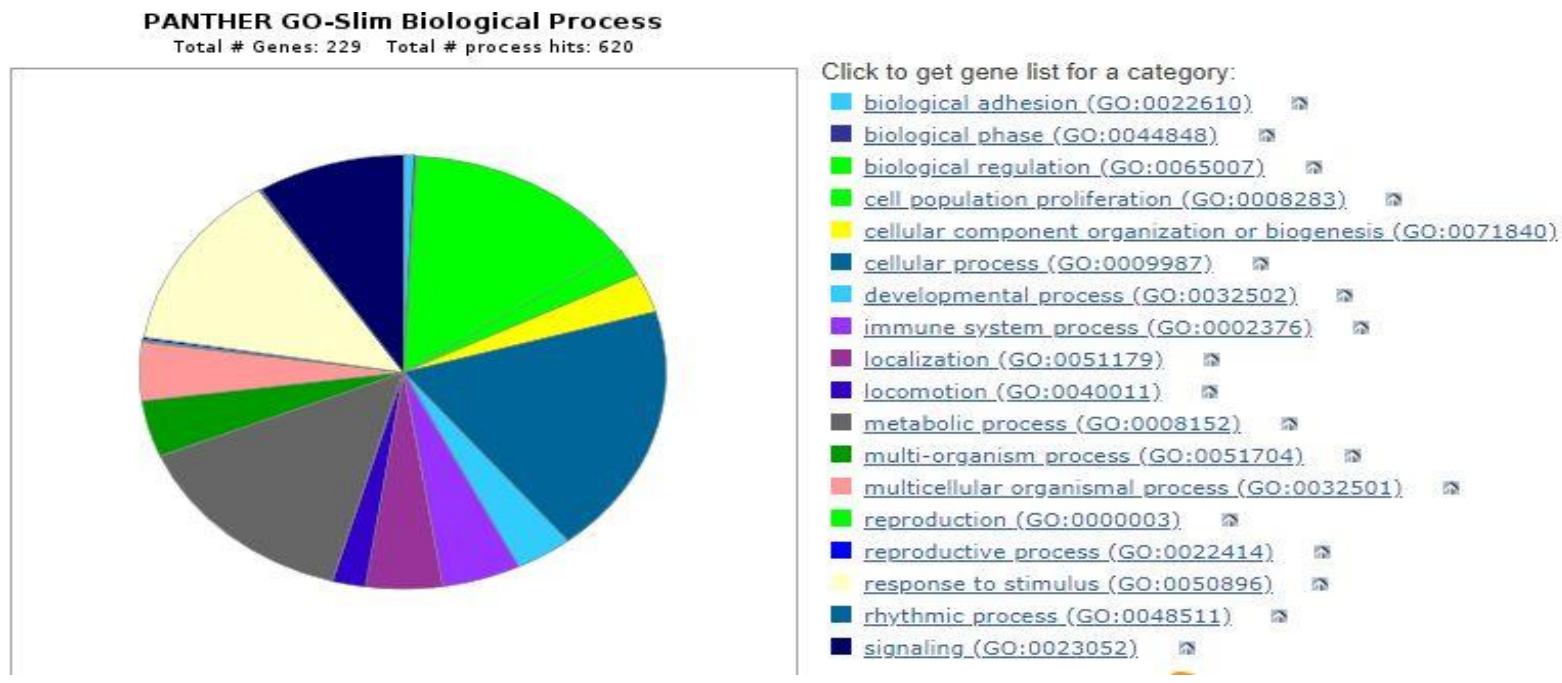

Figure 2: Gene ontology (BO) analysis of COVID-19 genes for selection of statistically significant genes using gene enrichment analysis 


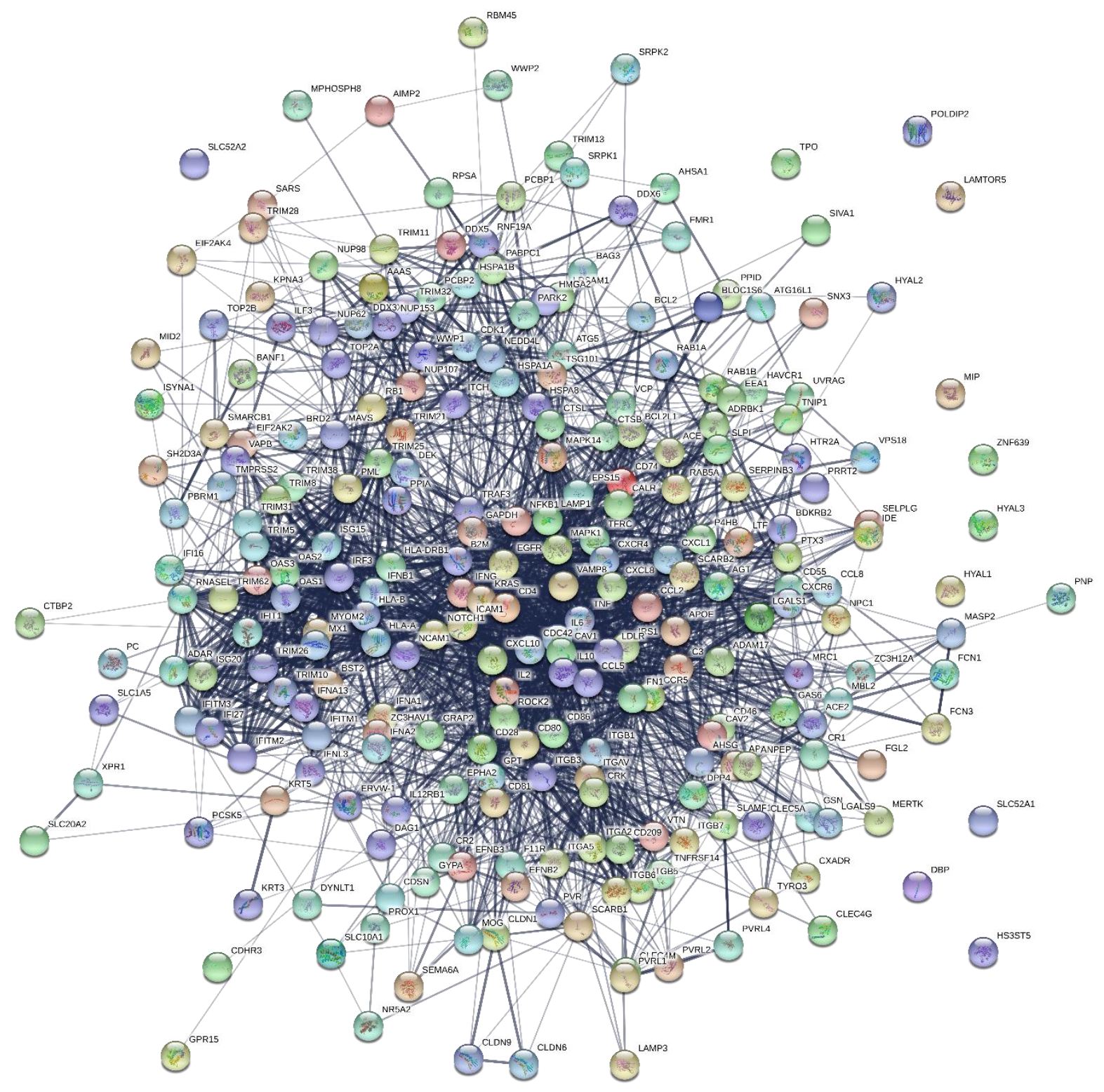

Figure 3: Protein-protein interaction of all 216 disease-gene association of COVID-19 showing 261 nodes and 2542 edges with average node degee 19.5 by using STRING database with setting greater than 0.4 


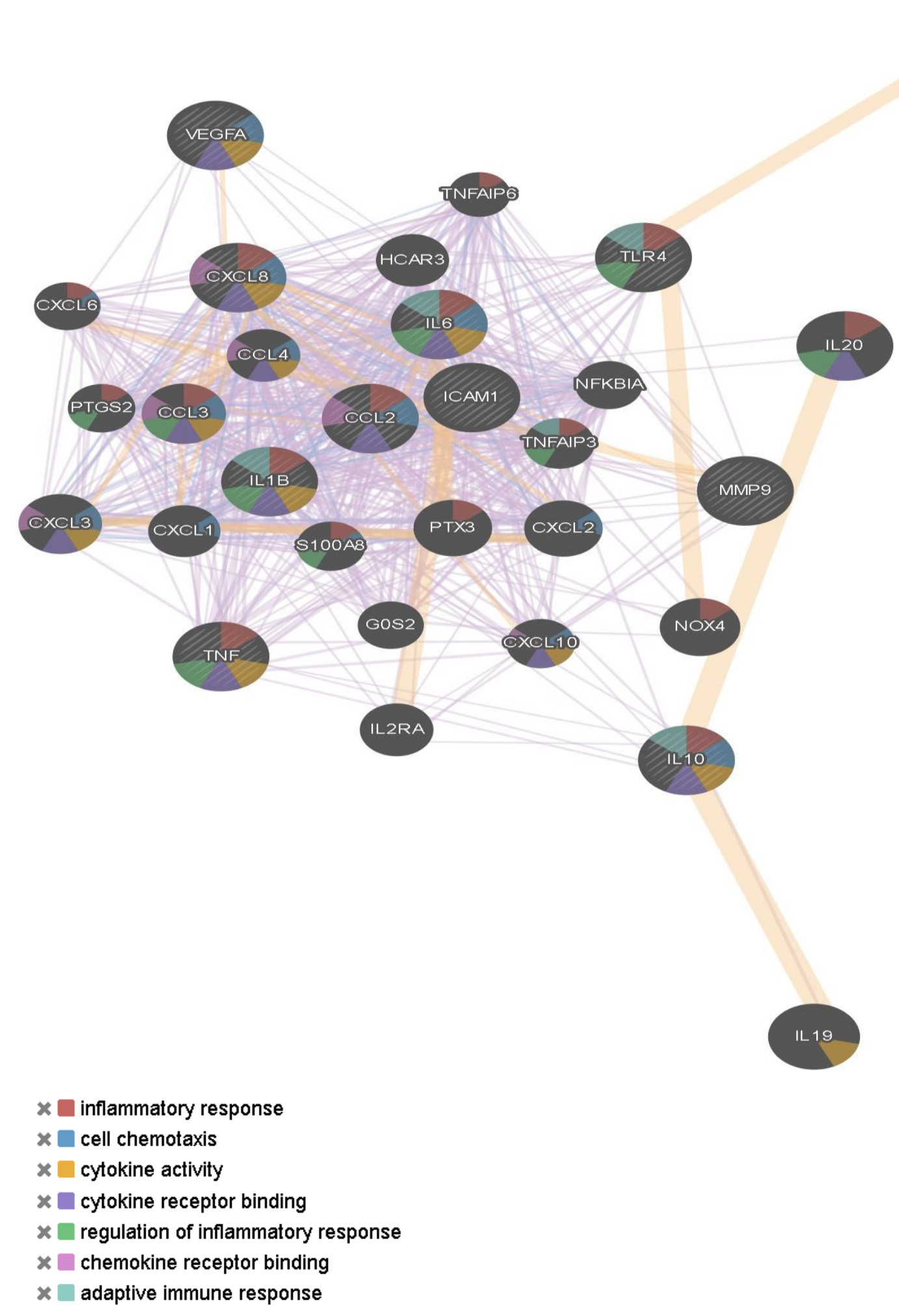

Figure 4: The predicted function of top 10 hub disease-gene network association of COVID-19 using gene mania 


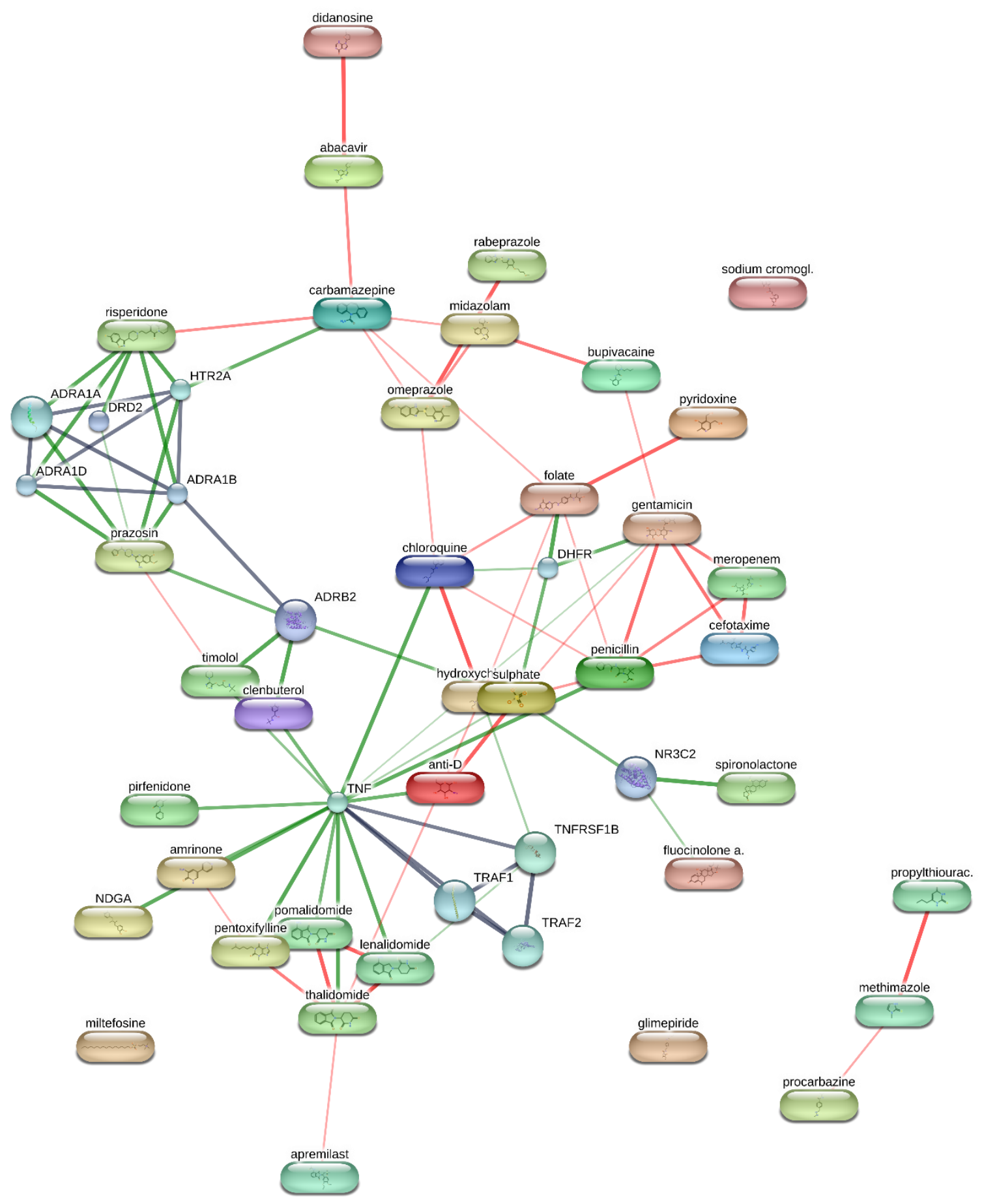

Figure 5: Drug-gene network of TNF and its druggable FDA approved drugs. The network shows cholorquine, hydrocholorquine and penicillin and other related drugs to the TNF network. 


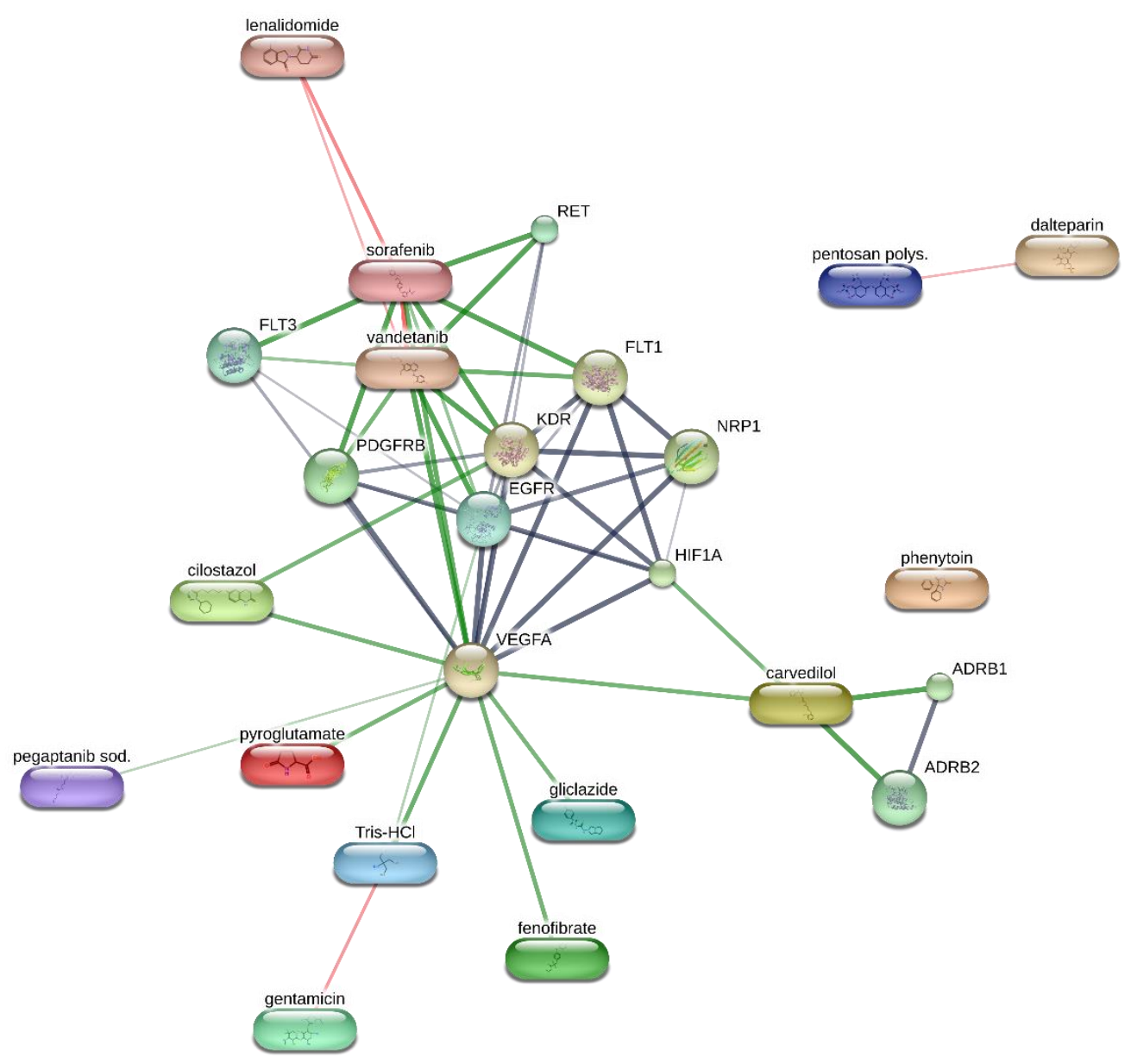

Figure 6: Drug-gene network of VEGFA using STITCH database 


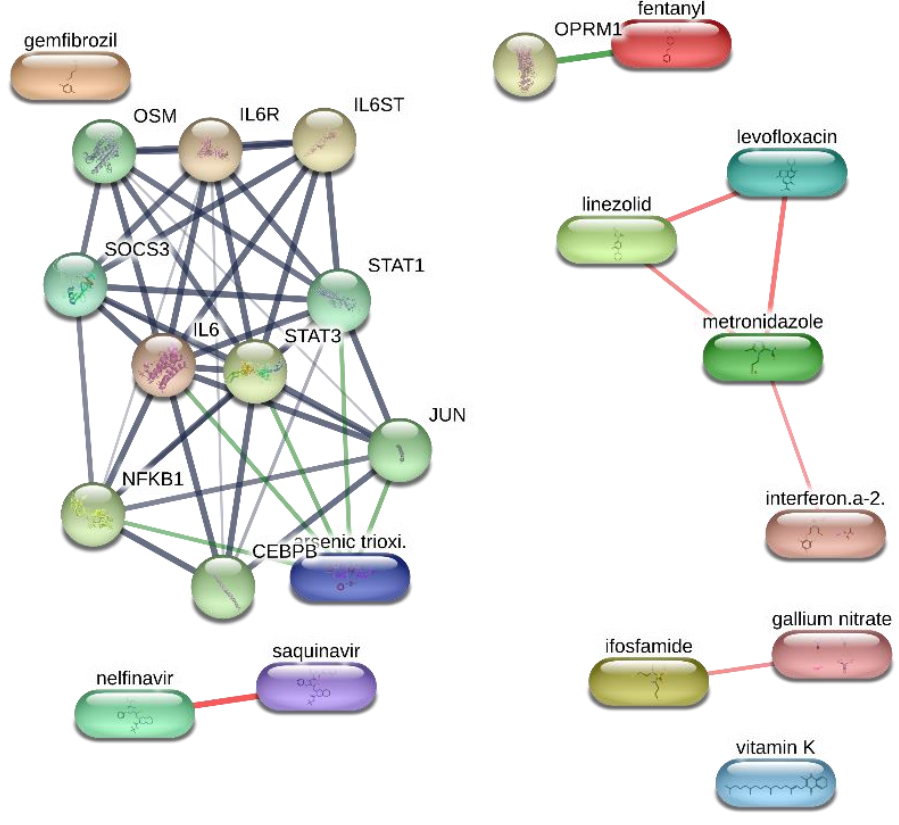

Figure 7: Drug-gene network of IL6 using STITCH database 


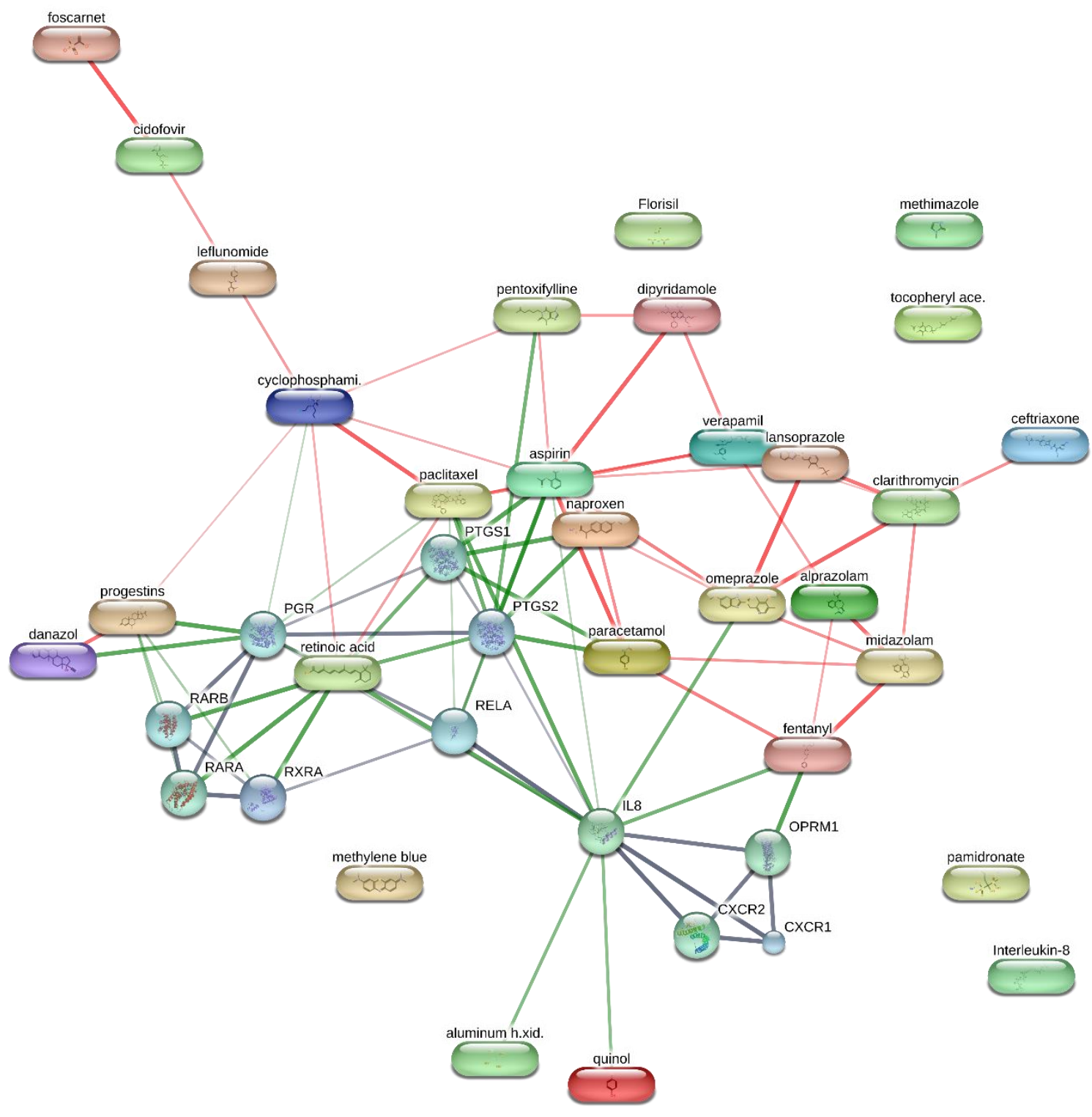

Figure 8: Drug-gene network of IL8 (CCL8) using STITCH database 


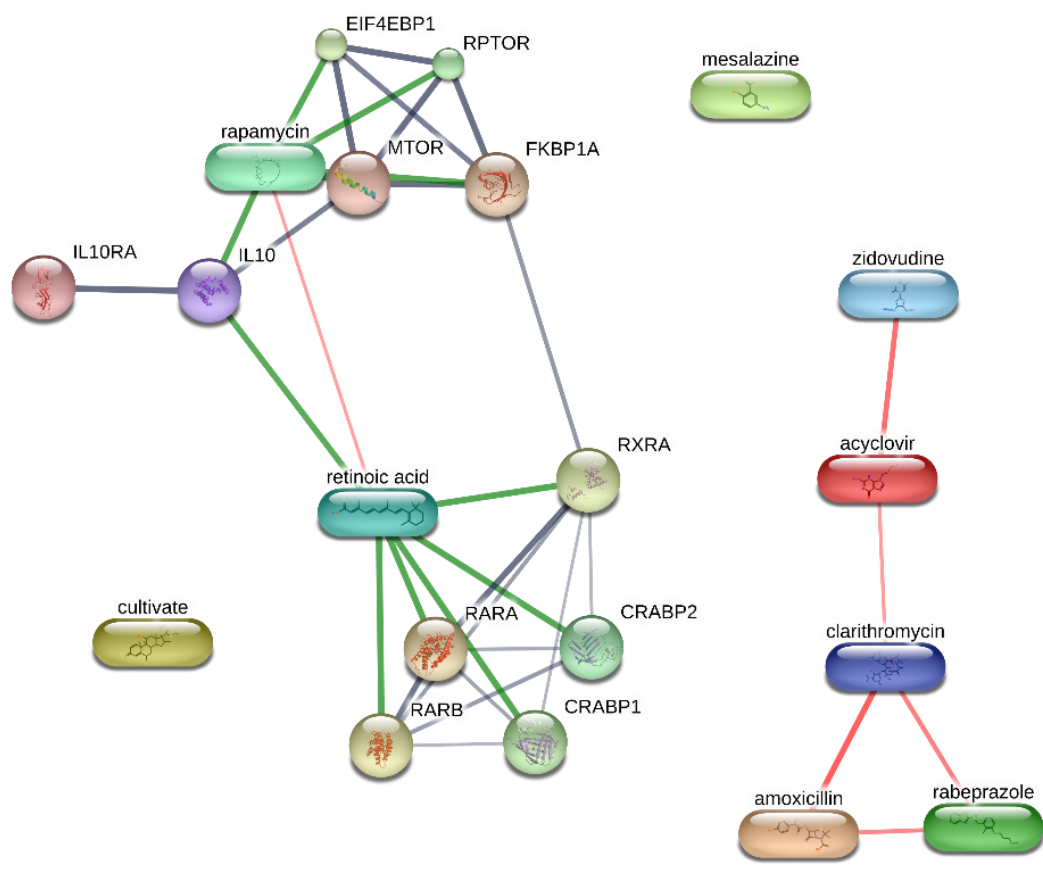

Figure 9: Drug-gene network of IL10

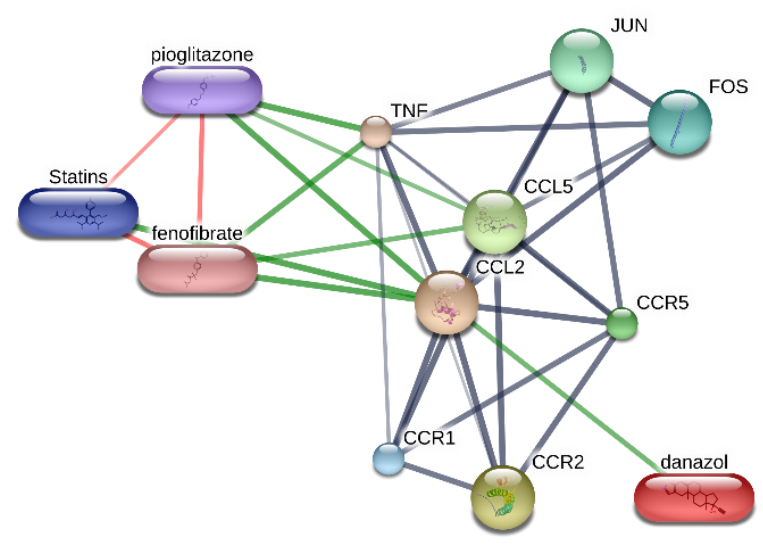

Figure 10: Drug-gene network of CCL2 


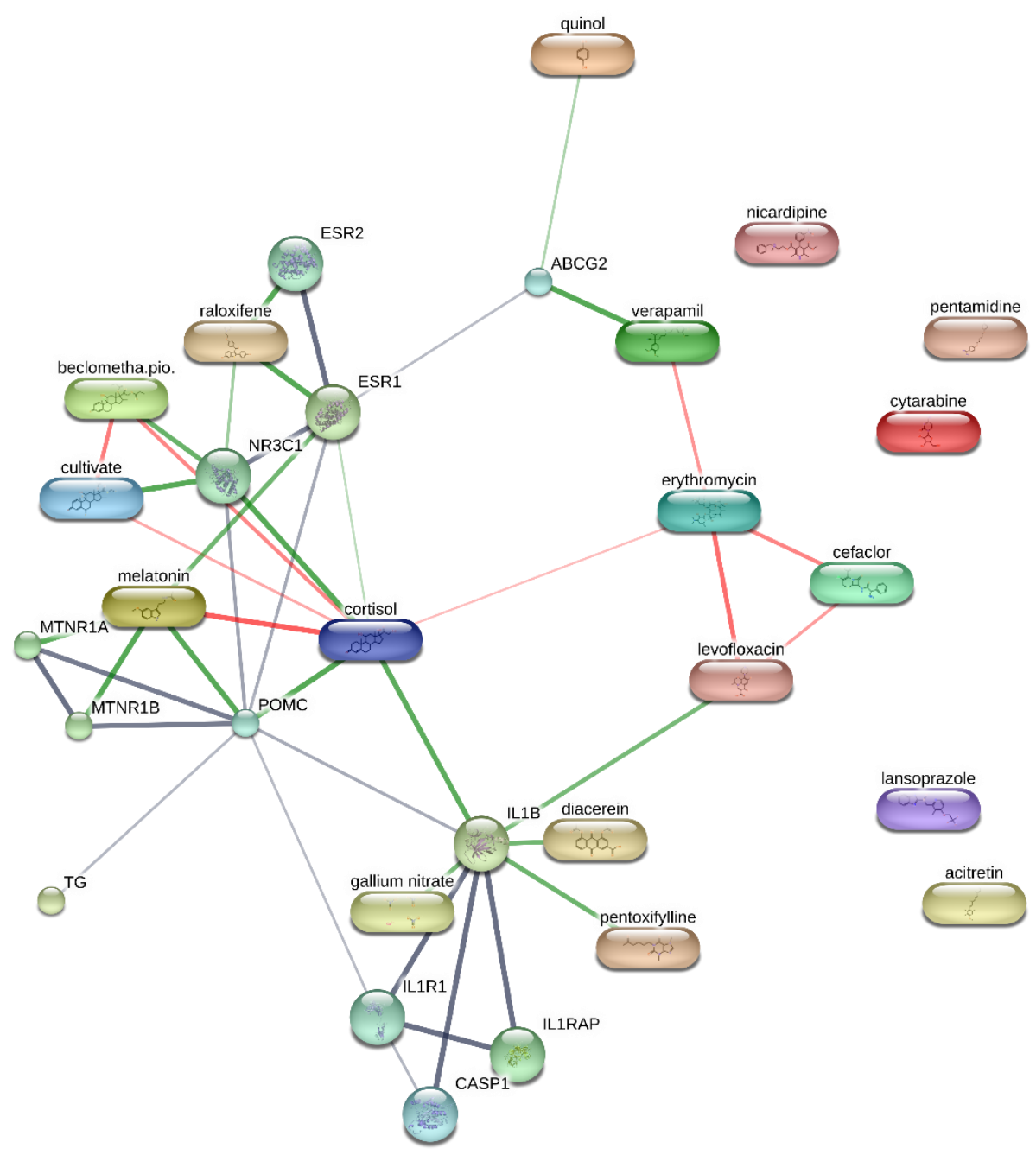

Figure 11: Drug-gene network of IL1B 


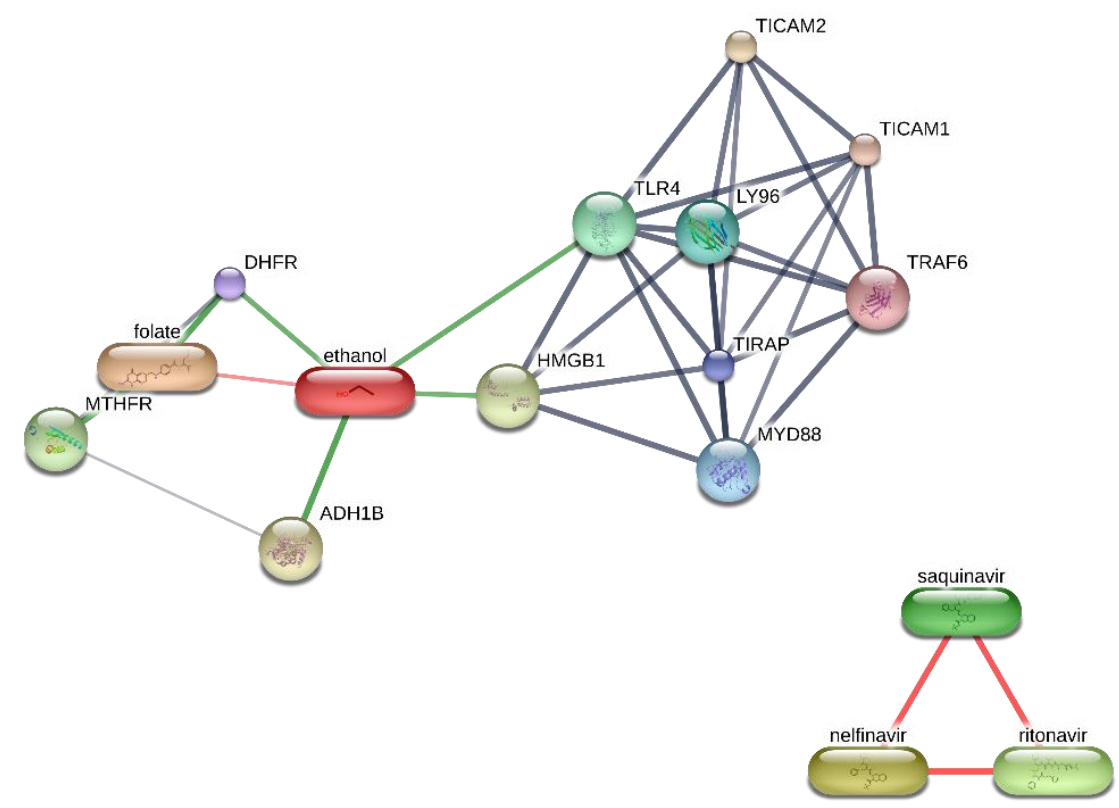

Figure 12: Drug-gene network of TLR4

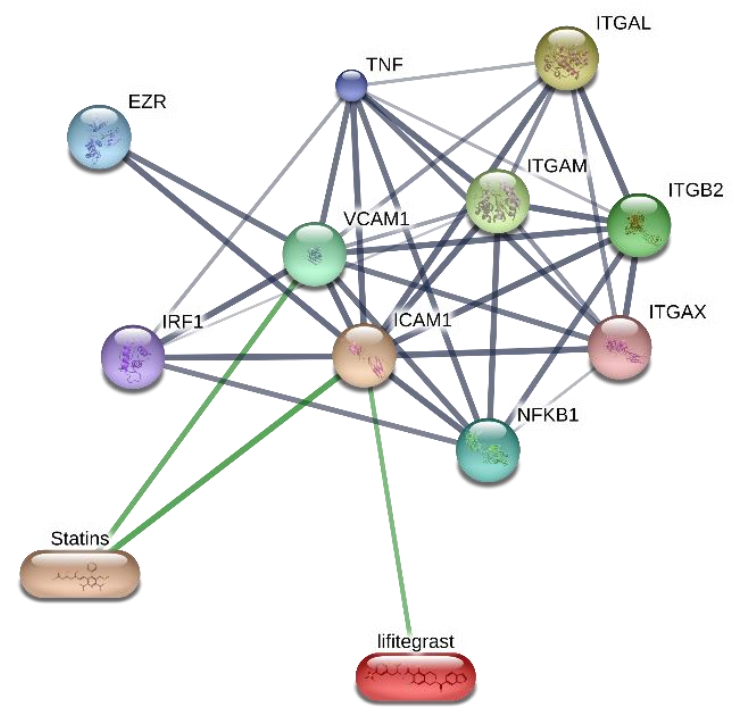

Figure 13: Drug-gene network of ICAM1 


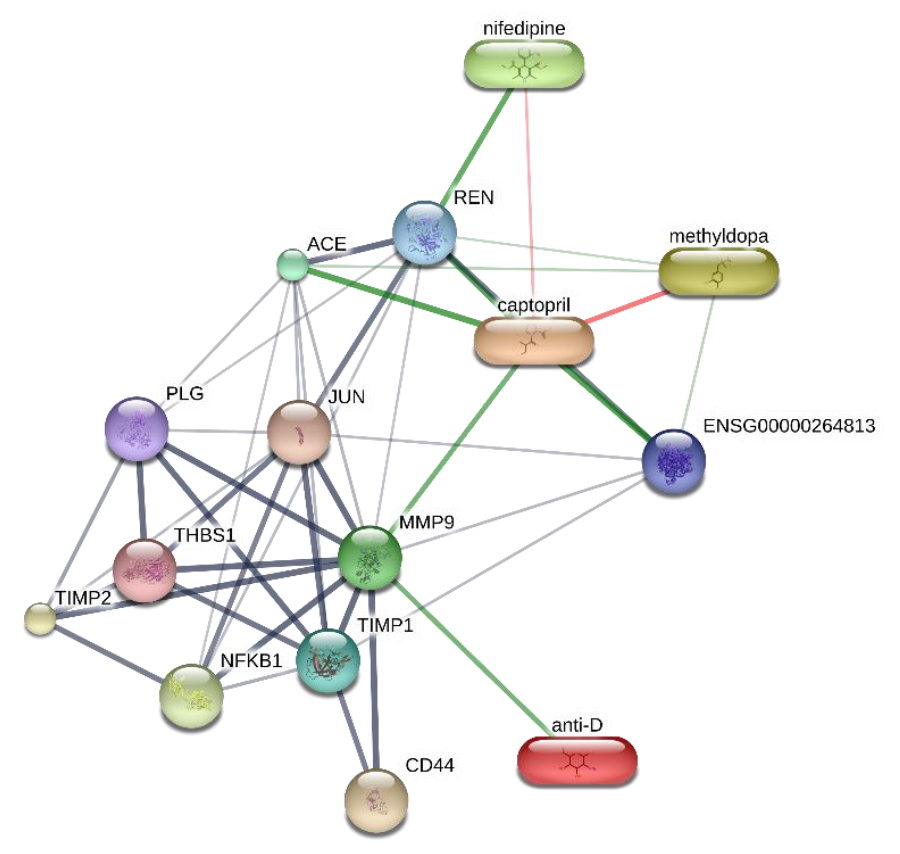

Figure 14: Drug-gene interaction of MMP9 


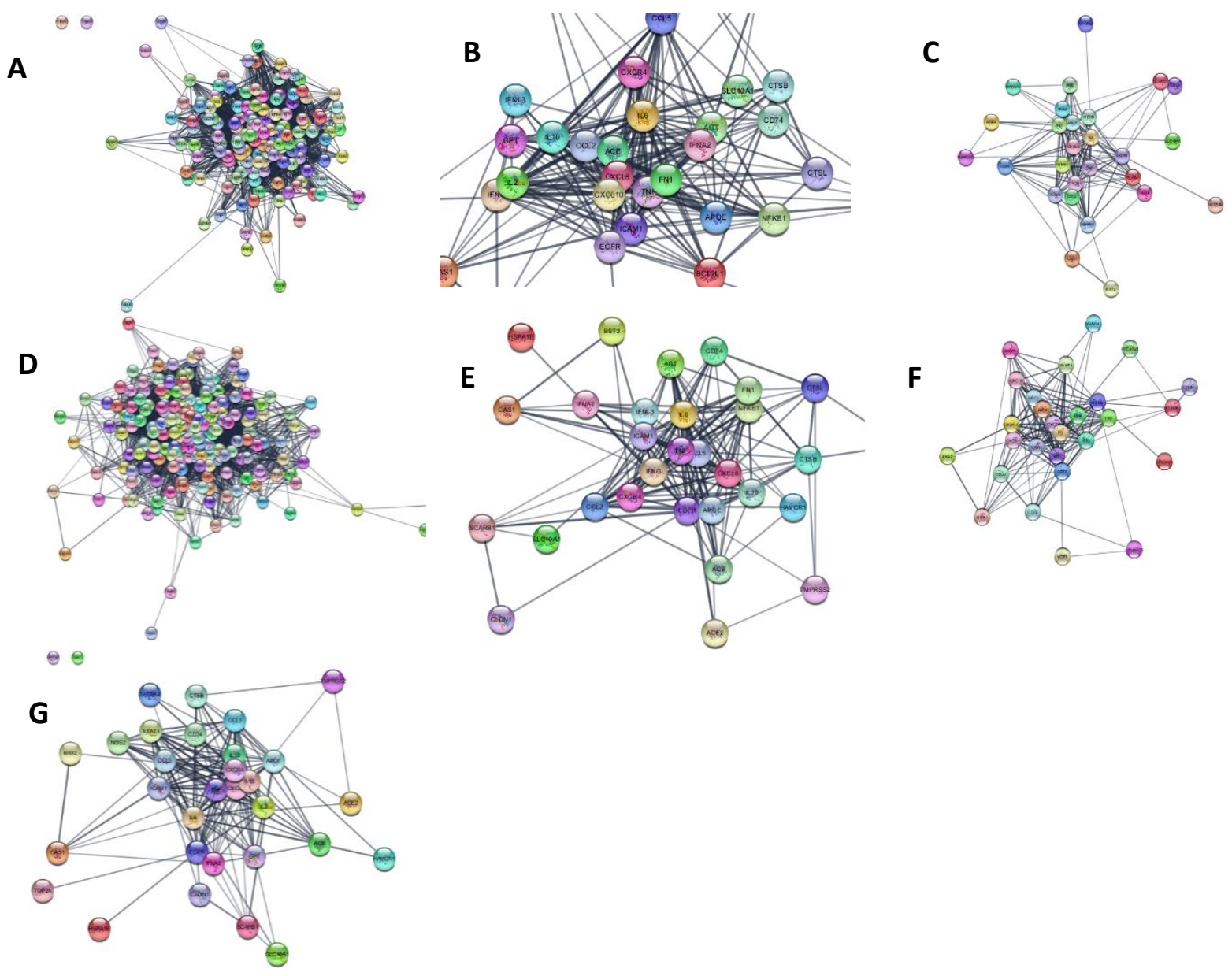

Figure 15: PPI network of high-risk and asymptomatic group of COVID-19. (A) Cancer (B) Diabetes (C) Heart Disease (D) Hypertension (E) Kidney Disease (F)Lung Disease (G) Asymptomatic 


\begin{tabular}{|c|c|c|c|c|}
\hline Uniprot ID & Gene ID & GENE SYMBOL & $\begin{array}{c}\text { PANTHER } \\
\text { FAMILY/SUBFAMILY }\end{array}$ & $\begin{array}{c}\text { PANTHER PROTEIN } \\
\text { CLASS }\end{array}$ \\
\hline P78310 & CXADR & $\begin{array}{l}\text { Coxsackievirus and adenovirus } \\
\text { receptor } \\
\text { CXADR } \\
\text { ortholog }\end{array}$ & $\begin{array}{l}\text { COXSACKIEVIRUS AND } \\
\text { ADENOVIRUS RECEPTOR } \\
\text { (PTHR44468:SF3) }\end{array}$ & - \\
\hline P11226 & MBL2 & $\begin{array}{l}\text { Mannose-binding protein } \mathrm{C} \\
\text { MBL2 } \\
\text { ortholog }\end{array}$ & $\begin{array}{l}\text { COLLAGEN ALPHA-1(XXI) } \\
\text { CHAIN-RELATED } \\
\text { (PTHR24020:SF20) }\end{array}$ & $\begin{array}{l}\text { extracellular matrix } \\
\text { structural protein }\end{array}$ \\
\hline Q9H3H5 & GPT & $\begin{array}{l}\text { UDP-N-acetylglucosamine-- } \\
\text { dolichyl-phosphate N- } \\
\text { acetylglucosaminephosphotransfe } \\
\text { rase } \\
\text { DPAGT1 } \\
\text { ortholog }\end{array}$ & $\begin{array}{l}\text { UDP-N- } \\
\text { ACETYLGLUCOSAMINE-- } \\
\text { DOLICHYL-PHOSPHATE N- } \\
\text { ACETYLGLUCOSAMINEPHOS } \\
\text { PHOTRANSFERASE } \\
\text { (PTHR10571:SF0) }\end{array}$ & glycosyltransferase \\
\hline P01911 & $\begin{array}{l}\text { HLA- } \\
\text { DRB1 }\end{array}$ & $\begin{array}{l}\text { HLA class II histocompatibility } \\
\text { antigen, DRB1-15 beta chain } \\
\text { HLA-DRB1 } \\
\text { ortholog }\end{array}$ & $\begin{array}{l}\text { HLA CLASS II } \\
\text { HISTOCOMPATIBILITY } \\
\text { ANTIGEN, DRB1-15 BETA } \\
\text { CHAIN (PTHR19944:SF99) }\end{array}$ & $\begin{array}{l}\text { major histocompatibility } \\
\text { complex protein }\end{array}$ \\
\hline P29317 & EPHA2 & $\begin{array}{l}\text { Ephrin type-A receptor } 2 \\
\text { EPHA2 } \\
\text { ortholog }\end{array}$ & $\begin{array}{l}\text { EPHRIN TYPE-A RECEPTOR } 2 \\
\text { (PTHR24416:SF306) }\end{array}$ & - \\
\hline P01019 & AGT & $\begin{array}{l}\text { Angiotensinogen } \\
\text { AGT } \\
\text { ortholog }\end{array}$ & $\begin{array}{l}\text { ANGIOTENSINOGEN } \\
\text { (PTHR11461:SF331) }\end{array}$ & protease inhibitor \\
\hline Q14258 & TRIM25 & $\begin{array}{l}\text { E3 ubiquitin/ISG15 ligase } \\
\text { TRIM25 } \\
\text { TRIM25 } \\
\text { ortholog }\end{array}$ & $\begin{array}{l}\text { E3 UBIQUITIN/ISG15 LIGASE } \\
\text { TRIM25 (PTHR25465:SF17) }\end{array}$ & - \\
\hline P05106 & ITGB3 & $\begin{array}{l}\text { Integrin beta-3 } \\
\text { ITGB3 } \\
\text { ortholog }\end{array}$ & $\begin{array}{l}\text { INTEGRIN BETA-3 } \\
\text { (PTHR10082:SF25) }\end{array}$ & cell adhesion molecule \\
\hline P18084 & ITGB5 & $\begin{array}{l}\text { Integrin beta-5 } \\
\text { ITGB5 } \\
\text { ortholog }\end{array}$ & $\begin{array}{l}\text { INTEGRIN BETA-5 } \\
\text { (PTHR10082:SF26) }\end{array}$ & cell adhesion molecule \\
\hline P13647 & K5 & $\begin{array}{l}\text { Keratin, type II cytoskeletal } 5 \\
\text { KRT5 } \\
\text { ortholog }\end{array}$ & $\begin{array}{l}\text { KERATIN, TYPE II } \\
\text { CYTOSKELETAL } 5 \\
\text { (PTHR45616:SF32) } \\
\end{array}$ & - \\
\hline $\mathrm{P} 40305$ & IFI27 & $\begin{array}{l}\text { Interferon alpha-inducible protein } \\
27, \text { mitochondrial } \\
\text { IFI } 27 \\
\text { ortholog }\end{array}$ & $\begin{array}{l}\text { INTERFERON ALPHA- } \\
\text { INDUCIBLE PROTEIN 27, } \\
\text { MITOCHONDRIAL } \\
\text { (PTHR16932:SF15) }\end{array}$ & - \\
\hline P01563 & IFNA2 & $\begin{array}{l}\text { Interferon alpha-2 } \\
\text { IFNA2 } \\
\text { ortholog }\end{array}$ & $\begin{array}{l}\text { INTERFERON ALPHA-2 } \\
\text { (PTHR11691:SF60) }\end{array}$ & - \\
\hline Q99797 & MIP & $\begin{array}{l}\text { Mitochondrial intermediate } \\
\text { peptidase } \\
\text { MIPEP } \\
\text { ortholog }\end{array}$ & $\begin{array}{l}\text { MITOCHONDRIAL } \\
\text { INTERMEDIATE PEPTIDASE } \\
\text { (PTHR11804:SF5) }\end{array}$ & metalloprotease \\
\hline P08648 & ITGA5 & $\begin{array}{l}\text { Integrin alpha-5 } \\
\text { ITGA5 } \\
\text { ortholog }\end{array}$ & $\begin{array}{l}\text { INTEGRIN ALPHA-5 } \\
\text { (PTHR23220:SF3) }\end{array}$ & - \\
\hline O75636 & FCN3 & $\begin{array}{l}\text { Ficolin-3 } \\
\text { FCN3 } \\
\text { ortholog }\end{array}$ & FICOLIN-3 (PTHR19143:SF373) & $\begin{array}{l}\text { intercellular signal } \\
\text { molecule }\end{array}$ \\
\hline P11142 & HSPA8 & $\begin{array}{l}\text { Heat shock cognate } 71 \mathrm{kDa} \\
\text { protein }\end{array}$ & $\begin{array}{l}\text { HEAT SHOCK COGNATE } 71 \\
\text { KDA PROTEIN }\end{array}$ & - \\
\hline
\end{tabular}




\begin{tabular}{|c|c|c|c|c|}
\hline & & $\begin{array}{l}\text { HSPA8 } \\
\text { ortholog }\end{array}$ & (PTHR19375:SF379) & \\
\hline P05231 & IL6 & $\begin{array}{l}\text { Interleukin-6 } \\
\text { IL6 } \\
\text { ortholog }\end{array}$ & $\begin{array}{l}\text { INTERLEUKIN-6 } \\
\text { (PTHR10511:SF3) }\end{array}$ & - \\
\hline Q15025 & TNIP1 & $\begin{array}{l}\text { TNFAIP3-interacting protein } 1 \\
\text { TNIP1 } \\
\text { ortholog }\end{array}$ & $\begin{array}{l}\text { TNFAIP3-INTERACTING } \\
\text { PROTEIN } 1 \text { (PTHR31882:SF3) }\end{array}$ & - \\
\hline P11498 & $\mathrm{PC}$ & $\begin{array}{l}\text { Pyruvate carboxylase, } \\
\text { mitochondrial } \\
\text { PC } \\
\text { ortholog }\end{array}$ & $\begin{array}{l}\text { PYRUVATE CARBOXYLASE, } \\
\text { MITOCHONDRIAL } \\
\text { (PTHR43778:SF2) }\end{array}$ & ligase \\
\hline Q96D42 & HAVCR1 & $\begin{array}{l}\text { Hepatitis A virus cellular receptor } \\
1 \\
\text { HAVCR1 } \\
\text { ortholog }\end{array}$ & $\begin{array}{l}\text { HEPATITIS A VIRUS } \\
\text { CELLULAR RECEPTOR } 1 \\
\text { (PTHR47009:SF7) }\end{array}$ & - \\
\hline P10145 & CXCL8 & $\begin{array}{l}\text { Interleukin-8 } \\
\text { CXCL8 } \\
\text { ortholog }\end{array}$ & $\begin{array}{l}\text { INTERLEUKIN-8 } \\
\text { (PTHR10179:SF42) }\end{array}$ & chemokine \\
\hline P21549 & AGT & $\begin{array}{l}\text { Serine--pyruvate aminotransferase } \\
\text { AGXT } \\
\text { ortholog }\end{array}$ & $\begin{array}{l}\text { SERINE--PYRUVATE } \\
\text { AMINOTRANSFERASE } \\
\text { (PTHR21152:SF24) }\end{array}$ & transaminase \\
\hline Q9NY35 & CLDN1 & $\begin{array}{l}\text { Claudin domain-containing } \\
\text { protein } 1 \\
\text { CLDND1 } \\
\text { ortholog }\end{array}$ & $\begin{array}{l}\text { CLAUDIN DOMAIN- } \\
\text { CONTAINING PROTEIN } 1 \\
\text { (PTHR14347:SF3) }\end{array}$ & - \\
\hline P60033 & CD81 & $\begin{array}{l}\text { CD81 antigen } \\
\text { CD81 } \\
\text { ortholog }\end{array}$ & $\begin{array}{l}\text { CD81 ANTIGEN } \\
\text { (PTHR19282:SF214) }\end{array}$ & - \\
\hline P13501 & CCL5 & $\begin{array}{l}\text { C-C motif chemokine } 5 \\
\text { CCL5 } \\
\text { ortholog }\end{array}$ & $\begin{array}{l}\text { C-C MOTIF CHEMOKINE } 5 \\
\text { (PTHR12015:SF170) }\end{array}$ & cytokine \\
\hline P04406 & GAPDH & $\begin{array}{l}\text { Glyceraldehyde-3-phosphate } \\
\text { dehydrogenase } \\
\text { GAPDH } \\
\text { ortholog }\end{array}$ & $\begin{array}{l}\text { GLYCERALDEHYDE-3- } \\
\text { PHOSPHATE } \\
\text { DEHYDROGENASE } \\
\text { (PTHR10836:SF111) }\end{array}$ & dehydrogenase \\
\hline $\mathrm{P} 46531$ & NOTCH1 & $\begin{array}{l}\text { Neurogenic locus notch homolog } \\
\text { protein } 1 \\
\text { NOTCH1 } \\
\text { ortholog }\end{array}$ & $\begin{array}{l}\text { NEUROGENIC LOCUS NOTCH } \\
\text { HOMOLOG PROTEIN } 1 \\
\text { (PTHR45836:SF12) }\end{array}$ & - \\
\hline P08865 & RPSA & $\begin{array}{l}40 \mathrm{~S} \text { ribosomal protein } \mathrm{SA} \\
\text { RPSA } \\
\text { ortholog }\end{array}$ & $\begin{array}{l}\text { 40S RIBOSOMAL PROTEIN SA } \\
\text { (PTHR11489:SF17) }\end{array}$ & ribosomal protein \\
\hline P17301 & ITGA2 & $\begin{array}{l}\text { Integrin alpha-2 } \\
\text { ITGA2 } \\
\text { ortholog }\end{array}$ & $\begin{array}{l}\text { INTEGRIN ALPHA-2 } \\
\text { (PTHR23220:SF23) }\end{array}$ & - \\
\hline P17927 & CR1 & $\begin{array}{l}\text { Complement receptor type } 1 \\
\text { CR1 } \\
\text { ortholog }\end{array}$ & $\begin{array}{l}\text { COMPLEMENT RECEPTOR } \\
\text { TYPE } 1 \text { (PTHR19325:SF505) }\end{array}$ & - \\
\hline P13164 & IFITM1 & $\begin{array}{l}\text { Interferon-induced } \\
\text { transmembrane protein } 1 \\
\text { IFITM1 } \\
\text { ortholog }\end{array}$ & $\begin{array}{l}\text { INTERFERON-INDUCED } \\
\text { TRANSMEMBRANE PROTEIN } \\
1 \text { (PTHR13999:SF6) }\end{array}$ & - \\
\hline Q96SB4 & SRPK1 & $\begin{array}{l}\text { SRSF protein kinase } 1 \\
\text { SRPK1 } \\
\text { ortholog }\end{array}$ & $\begin{array}{l}\text { SRSF PROTEIN KINASE } 1 \\
\text { (PTHR24055:SF0) }\end{array}$ & $\begin{array}{l}\text { non-receptor } \\
\text { serine/threonine protein } \\
\text { kinase }\end{array}$ \\
\hline P0DMV9 & HSPA1B & $\begin{array}{l}\text { Heat shock } 70 \mathrm{kDa} \text { protein } 1 \mathrm{~B} \\
\text { HSPA1B } \\
\text { ortholog }\end{array}$ & $\begin{array}{l}\text { HEAT SHOCK } 70 \text { KDA } \\
\text { PROTEIN 1A-RELATED } \\
\text { (PTHR19375:SF223) }\end{array}$ & - \\
\hline
\end{tabular}




\begin{tabular}{|c|c|c|c|c|}
\hline P42081 & CD86 & $\begin{array}{l}\text { T-lymphocyte activation antigen } \\
\text { CD86 } \\
\text { CD86 } \\
\text { ortholog }\end{array}$ & $\begin{array}{l}\text { T-LYMPHOCYTE } \\
\text { ACTIVATION ANTIGEN CD86 } \\
\text { (PTHR25466:SF2) }\end{array}$ & $\begin{array}{l}\text { immunoglobulin receptor } \\
\text { superfamily }\end{array}$ \\
\hline O75364 & PTX3 & $\begin{array}{l}\text { Pituitary homeobox } 3 \\
\text { PITX3 } \\
\text { ortholog }\end{array}$ & $\begin{array}{l}\text { PITUITARY HOMEOBOX } 3 \\
\text { (PTHR45882:SF2) }\end{array}$ & - \\
\hline P27797 & CALR & $\begin{array}{l}\text { Calreticulin } \\
\text { CALR } \\
\text { ortholog }\end{array}$ & $\begin{array}{l}\text { CALRETICULIN } \\
\text { (PTHR11073:SF16) }\end{array}$ & chaperone \\
\hline Q14314 & FGL2 & $\begin{array}{l}\text { Fibroleukin } \\
\text { FGL2 } \\
\text { ortholog }\end{array}$ & $\begin{array}{l}\text { FIBROLEUKIN } \\
\text { (PTHR19143:SF189) }\end{array}$ & $\begin{array}{l}\text { intercellular signal } \\
\text { molecule }\end{array}$ \\
\hline Q96J02 & ITCH & $\begin{array}{l}\text { E3 ubiquitin-protein ligase Itchy } \\
\text { homolog } \\
\text { ITCH } \\
\text { ortholog }\end{array}$ & $\begin{array}{l}\text { E3 UBIQUITIN-PROTEIN } \\
\text { LIGASE ITCHY HOMOLOG } \\
\text { (PTHR11254:SF66) }\end{array}$ & ubiquitin-protein ligase \\
\hline Q12866 & MERTK & $\begin{array}{l}\text { Tyrosine-protein kinase Mer } \\
\text { MERTK } \\
\text { ortholog }\end{array}$ & $\begin{array}{l}\text { TYROSINE-PROTEIN KINASE } \\
\text { MER (PTHR24416:SF257) }\end{array}$ & - \\
\hline Q15366 & PCBP2 & $\begin{array}{l}\text { Poly(rC)-binding protein } 2 \\
\text { PCBP2 } \\
\text { ortholog }\end{array}$ & $\begin{array}{l}\text { POLY(RC)-BINDING PROTEIN } \\
2 \text { (PTHR10288:SF97) }\end{array}$ & RNA binding protein \\
\hline P29590 & PML & $\begin{array}{l}\text { Protein PML } \\
\text { PML } \\
\text { ortholog }\end{array}$ & $\begin{array}{l}\text { PROTEIN PML } \\
\text { (PTHR25462:SF241) }\end{array}$ & - \\
\hline P22897 & MRC1 & $\begin{array}{l}\text { Macrophage mannose receptor } 1 \\
\text { MRC1 } \\
\text { ortholog }\end{array}$ & $\begin{array}{l}\text { MACROPHAGE MANNOSE } \\
\text { RECEPTOR } 1 \\
\text { (PTHR22803:SF104) }\end{array}$ & - \\
\hline P11388 & TOP2A & $\begin{array}{l}\text { DNA topoisomerase } 2 \text {-alpha } \\
\text { TOP2A } \\
\text { ortholog }\end{array}$ & $\begin{array}{l}\text { DNA TOPOISOMERASE 2- } \\
\text { ALPHA (PTHR10169:SF61) }\end{array}$ & - \\
\hline $\mathrm{P} 40225$ & TPO & $\begin{array}{l}\text { Thrombopoietin } \\
\text { THPO } \\
\text { ortholog }\end{array}$ & $\begin{array}{l}\text { THROMBOPOIETIN } \\
\text { (PTHR10560:SF0) }\end{array}$ & - \\
\hline P18564 & ITGB6 & $\begin{array}{l}\text { Integrin beta-6 } \\
\text { ITGB6 } \\
\text { ortholog } \\
\end{array}$ & $\begin{array}{l}\text { INTEGRIN BETA-6 } \\
\text { (PTHR10082:SF11) }\end{array}$ & cell adhesion molecule \\
\hline P06400 & RB1 & $\begin{array}{l}\text { Retinoblastoma-associated } \\
\text { protein } \\
\text { RB1 } \\
\text { ortholog }\end{array}$ & $\begin{array}{l}\text { RETINOBLASTOMA- } \\
\text { ASSOCIATED PROTEIN } \\
\text { (PTHR13742:SF17) }\end{array}$ & $\begin{array}{l}\text { chromatin/chromatin- } \\
\text { binding, or -regulatory } \\
\text { protein }\end{array}$ \\
\hline P49591 & SARS & $\begin{array}{l}\text { Serine--tRNA ligase, cytoplasmic } \\
\text { SARS } \\
\text { ortholog }\end{array}$ & $\begin{array}{l}\text { SERINE--TRNA LIGASE, } \\
\text { CYTOPLASMIC-RELATED } \\
\text { (PTHR11778:SF7) }\end{array}$ & $\begin{array}{l}\text { aminoacyl-tRNA } \\
\text { synthetase }\end{array}$ \\
\hline P07237 & P4HB & $\begin{array}{l}\text { Protein disulfide-isomerase } \\
\text { P4HB } \\
\text { ortholog }\end{array}$ & $\begin{array}{l}\text { PROTEIN DISULFIDE- } \\
\text { ISOMERASE } \\
\text { (PTHR18929:SF101) }\end{array}$ & - \\
\hline O60858 & TRIM13 & $\begin{array}{l}\text { E3 ubiquitin-protein ligase } \\
\text { TRIM13 } \\
\text { TRIM13 } \\
\text { ortholog }\end{array}$ & $\begin{array}{l}\text { E3 UBIQUITIN-PROTEIN } \\
\text { LIGASE TRIM13 } \\
\text { (PTHR24103:SF609) }\end{array}$ & ubiquitin-protein ligase \\
\hline P52926 & HMGA2 & $\begin{array}{l}\text { High mobility group protein } \\
\text { HMGI-C } \\
\text { HMGA2 } \\
\text { ortholog }\end{array}$ & $\begin{array}{l}\text { HIGH MOBILITY GROUP } \\
\text { PROTEIN HMGI-C } \\
\text { (PTHR23341:SF4) }\end{array}$ & endodeoxyribonuclease \\
\hline P12035 & K3 & $\begin{array}{l}\text { Keratin, type II cytoskeletal } 3 \\
\text { KRT3 } \\
\text { ortholog }\end{array}$ & $\begin{array}{l}\text { KERATIN, TYPE II } \\
\text { CYTOSKELETAL } 3 \\
\text { (PTHR45616:SF38) } \\
\end{array}$ & - \\
\hline
\end{tabular}




\begin{tabular}{|c|c|c|c|c|}
\hline Q8IZI9 & IFNL3 & $\begin{array}{l}\text { Interferon lambda-3 } \\
\text { IFNL3 } \\
\text { ortholog }\end{array}$ & $\begin{array}{l}\text { INTERFERON LAMBDA-2- } \\
\text { RELATED (PTHR31943:SF1) }\end{array}$ & - \\
\hline Q10589 & BST2 & $\begin{array}{l}\text { Bone marrow stromal antigen } 2 \\
\text { BST2 } \\
\text { ortholog }\end{array}$ & $\begin{array}{l}\text { BONE MARROW STROMAL } \\
\text { ANTIGEN } 2 \text { (PTHR15190:SF1) }\end{array}$ & - \\
\hline Q14118 & DAG1 & $\begin{array}{l}\text { Dystroglycan } \\
\text { DAG1 } \\
\text { ortholog }\end{array}$ & $\begin{array}{l}\text { DYSTROGLYCAN } \\
\text { (PTHR21559:SF22) }\end{array}$ & cell adhesion molecule \\
\hline P33681 & CD80 & $\begin{array}{l}\text { T-lymphocyte activation antigen } \\
\text { CD80 } \\
\text { CD80 } \\
\text { ortholog }\end{array}$ & $\begin{array}{l}\text { T-LYMPHOCYTE } \\
\text { ACTIVATION ANTIGEN CD80 } \\
\text { (PTHR25466:SF4) }\end{array}$ & $\begin{array}{l}\text { immunoglobulin receptor } \\
\text { superfamily }\end{array}$ \\
\hline Q9UJV3 & MID2 & $\begin{array}{l}\text { Probable E3 ubiquitin-protein } \\
\text { ligase MID2 } \\
\text { MID2 } \\
\text { ortholog }\end{array}$ & $\begin{array}{l}\text { E3 UBIQUITIN-PROTEIN } \\
\text { LIGASE MID2-RELATED } \\
\text { (PTHR24099:SF12) }\end{array}$ & ubiquitin-protein ligase \\
\hline Q7Z434 & MAVS & $\begin{array}{l}\text { Mitochondrial antiviral-signaling } \\
\text { protein } \\
\text { MAVS } \\
\text { ortholog }\end{array}$ & $\begin{array}{l}\text { MITOCHONDRIAL } \\
\text { ANTIVIRAL-SIGNALING } \\
\text { PROTEIN (PTHR21446:SF6) }\end{array}$ & - \\
\hline O00505 & KPNA3 & $\begin{array}{l}\text { Importin subunit alpha-4 } \\
\text { KPNA3 } \\
\text { ortholog }\end{array}$ & $\begin{array}{l}\text { IMPORTIN SUBUNIT ALPHA- } \\
4 \text { (PTHR23316:SF6) }\end{array}$ & transporter \\
\hline Q14108 & SCARB2 & $\begin{array}{l}\text { Lysosome membrane protein } 2 \\
\text { SCARB2 } \\
\text { ortholog }\end{array}$ & $\begin{array}{l}\text { LYSOSOME MEMBRANE } \\
\text { PROTEIN } 2 \text { (PTHR11923:SF92) }\end{array}$ & $\begin{array}{l}\text { membrane trafficking } \\
\text { regulatory protein }\end{array}$ \\
\hline P51659 & DBP & $\begin{array}{l}\text { Peroxisomal multifunctional } \\
\text { enzyme type } 2 \\
\text { HSD17B4 } \\
\text { ortholog }\end{array}$ & $\begin{array}{l}\text { PEROXISOMAL } \\
\text { MULTIFUNCTIONAL } \\
\text { ENZYME TYPE } 2 \\
\text { (PTHR13078:SF56) }\end{array}$ & - \\
\hline P27487 & DPP4 & $\begin{array}{l}\text { Dipeptidyl peptidase } 4 \\
\text { DPP4 } \\
\text { ortholog }\end{array}$ & $\begin{array}{l}\text { DIPEPTIDYL PEPTIDASE } 4 \\
\text { (PTHR11731:SF128) }\end{array}$ & serine protease \\
\hline P30301 & MIP & $\begin{array}{l}\text { Lens fiber major intrinsic protein } \\
\text { MIP } \\
\text { ortholog }\end{array}$ & $\begin{array}{l}\text { LENS FIBER MAJOR } \\
\text { INTRINSIC PROTEIN } \\
\text { (PTHR19139:SF39) }\end{array}$ & transporter \\
\hline Q9P2Y5 & UVRAG & $\begin{array}{l}\text { UV radiation resistance- } \\
\text { associated gene protein } \\
\text { UVRAG } \\
\text { ortholog }\end{array}$ & $\begin{array}{l}\text { UV RADIATION } \\
\text { RESISTANCE-ASSOCIATED } \\
\text { GENE PROTEIN } \\
\text { (PTHR15157:SF5) }\end{array}$ & - \\
\hline P25440 & BRD2 & $\begin{array}{l}\text { Bromodomain-containing protein } \\
2 \\
\text { BRD2 } \\
\text { ortholog }\end{array}$ & $\begin{array}{l}\text { BROMODOMAIN- } \\
\text { CONTAINING PROTEIN } 2 \\
\text { (PTHR22880:SF225) }\end{array}$ & - \\
\hline P10747 & CD28 & $\begin{array}{l}\text { T-cell-specific surface } \\
\text { glycoprotein CD28 } \\
\text { CD28 } \\
\text { ortholog }\end{array}$ & $\begin{array}{l}\text { T-CELL-SPECIFIC SURFACE } \\
\text { GLYCOPROTEIN CD28 } \\
\text { (PTHR11494:SF7) }\end{array}$ & $\begin{array}{l}\text { immunoglobulin receptor } \\
\text { superfamily }\end{array}$ \\
\hline P55072 & VCP & $\begin{array}{l}\text { Transitional endoplasmic } \\
\text { reticulum ATPase } \\
\text { VCP } \\
\text { ortholog }\end{array}$ & $\begin{array}{l}\text { TRANSITIONAL } \\
\text { ENDOPLASMIC RETICULUM } \\
\text { ATPASE (PTHR23077:SF69) }\end{array}$ & - \\
\hline P26010 & ITGB7 & $\begin{array}{l}\text { Integrin beta-7 } \\
\text { ITGB7 } \\
\text { ortholog }\end{array}$ & $\begin{array}{l}\text { INTEGRIN BETA-7 } \\
\text { (PTHR10082:SF36) }\end{array}$ & cell adhesion molecule \\
\hline $\mathrm{P} 02774$ & DBP & $\begin{array}{l}\text { Vitamin D-binding protein } \\
\text { GC } \\
\text { ortholog }\end{array}$ & $\begin{array}{l}\text { VITAMIN D-BINDING } \\
\text { PROTEIN (PTHR11385:SF11) }\end{array}$ & transfer/carrier protein \\
\hline
\end{tabular}




\begin{tabular}{|c|c|c|c|c|}
\hline Q92973 & MIP & $\begin{array}{l}\text { Transportin-1 } \\
\text { TNPO1 } \\
\text { ortholog }\end{array}$ & $\begin{array}{l}\text { TRANSPORTIN-1 } \\
\text { (PTHR10527:SF21) }\end{array}$ & transporter \\
\hline P06396 & GSN & $\begin{array}{l}\text { Gelsolin } \\
\text { GSN } \\
\text { ortholog }\end{array}$ & $\begin{array}{l}\text { GELSOLIN-RELATED } \\
\text { (PTHR11977:SF29) }\end{array}$ & $\begin{array}{l}\text { non-motor actin binding } \\
\text { protein }\end{array}$ \\
\hline P01579 & IFNG & $\begin{array}{l}\text { Interferon gamma } \\
\text { IFNG } \\
\text { ortholog }\end{array}$ & $\begin{array}{l}\text { INTERFERON GAMMA } \\
\text { (PTHR11419:SF0) }\end{array}$ & - \\
\hline Q9NNX6 & CD209 & $\begin{array}{l}\text { CD209 antigen } \\
\text { CD209 } \\
\text { ortholog }\end{array}$ & $\begin{array}{l}\text { CD209 ANTIGEN } \\
\text { (PTHR22802:SF400) }\end{array}$ & membrane traffic protein \\
\hline Q16653 & MOG & $\begin{array}{l}\text { Myelin-oligodendrocyte } \\
\text { glycoprotein } \\
\text { MOG } \\
\text { ortholog }\end{array}$ & $\begin{array}{l}\text { MYELIN- } \\
\text { OLIGODENDROCYTE } \\
\text { GLYCOPROTEIN } \\
\text { (PTHR24100:SF71) }\end{array}$ & $\begin{array}{l}\text { immunoglobulin receptor } \\
\text { superfamily }\end{array}$ \\
\hline Q13263 & TRIM28 & $\begin{array}{l}\text { Transcription intermediary factor } \\
\text { 1-beta } \\
\text { TRIM28 } \\
\text { ortholog }\end{array}$ & $\begin{array}{l}\text { TRANSCRIPTION } \\
\text { INTERMEDIARY FACTOR 1- } \\
\text { BETA (PTHR25462:SF274) }\end{array}$ & - \\
\hline Q9C035 & TRIM5 & $\begin{array}{l}\text { Tripartite motif-containing } \\
\text { protein } 5 \\
\text { TRIM5 } \\
\text { ortholog }\end{array}$ & $\begin{array}{l}\text { TRIPARTITE MOTIF- } \\
\text { CONTAINING PROTEIN } 5 \\
\text { (PTHR24103:SF642) }\end{array}$ & ubiquitin-protein ligase \\
\hline $\mathrm{P} 02778$ & CXCL10 & $\begin{array}{l}\text { C-X-C motif chemokine } 10 \\
\text { CXCL10 } \\
\text { ortholog }\end{array}$ & $\begin{array}{l}\text { C-X-C MOTIF CHEMOKINE } 10 \\
\text { (PTHR10179:SF47) }\end{array}$ & chemokine \\
\hline Q96PU5 & NEDD4L & $\begin{array}{l}\text { E3 ubiquitin-protein ligase } \\
\text { NEDD4-like } \\
\text { NEDD4L } \\
\text { ortholog }\end{array}$ & $\begin{array}{l}\text { E3 UBIQUITIN-PROTEIN } \\
\text { LIGASE NEDD4-LIKE } \\
\text { (PTHR11254:SF310) }\end{array}$ & ubiquitin-protein ligase \\
\hline Q9P253 & VPS18 & $\begin{array}{l}\text { Vacuolar protein sorting- } \\
\text { associated protein } 18 \text { homolog } \\
\text { VPS18 } \\
\text { ortholog }\end{array}$ & $\begin{array}{l}\text { VACUOLAR PROTEIN } \\
\text { SORTING-ASSOCIATED } \\
\text { PROTEIN 18 HOMOLOG } \\
\text { (PTHR23323:SF26) }\end{array}$ & $\begin{array}{l}\text { membrane trafficking } \\
\text { regulatory protein }\end{array}$ \\
\hline P20339 & RAB5A & $\begin{array}{l}\text { Ras-related protein Rab-5A } \\
\text { RAB5A } \\
\text { ortholog }\end{array}$ & $\begin{array}{l}\text { RAS-RELATED PROTEIN } \\
\text { RAB-5A (PTHR24073:SF1129) }\end{array}$ & - \\
\hline O75531 & BANF1 & $\begin{array}{l}\text { Barrier-to-autointegration factor } \\
\text { BANF1 } \\
\text { ortholog }\end{array}$ & $\begin{array}{l}\text { BARRIER-TO- } \\
\text { AUTOINTEGRATION FACTOR } \\
\text { (PTHR12912:SF10) }\end{array}$ & $\begin{array}{l}\text { chromatin/chromatin- } \\
\text { binding, or -regulatory } \\
\text { protein }\end{array}$ \\
\hline Q9Y6K5 & OAS3 & $\begin{array}{l}\text { 2'-5'-oligoadenylate synthase } 3 \\
\text { OAS3 } \\
\text { ortholog }\end{array}$ & $\begin{array}{l}\text { 2'-5'-OLIGOADENYLATE } \\
\text { SYNTHASE } 3 \\
\text { (PTHR11258:SF4) }\end{array}$ & nucleotidyltransferase \\
\hline Q14653 & IRF3 & $\begin{array}{l}\text { Interferon regulatory factor } 3 \\
\text { IRF3 } \\
\text { ortholog }\end{array}$ & $\begin{array}{l}\text { INTERFERON REGULATORY } \\
\text { FACTOR } 3 \text { (PTHR11949:SF1) }\end{array}$ & $\begin{array}{l}\text { winged helix/forkhead } \\
\text { transcription factor }\end{array}$ \\
\hline P63172 & DYNLT1 & $\begin{array}{l}\text { Dynein light chain Tctex-type } 1 \\
\text { DYNLT1 } \\
\text { ortholog }\end{array}$ & $\begin{array}{l}\text { DYNEIN LIGHT CHAIN } \\
\text { TCTEX-TYPE } 1 \\
\text { (PTHR21255:SF19) } \\
\end{array}$ & $\begin{array}{l}\text { microtubule or } \\
\text { microtubule-binding } \\
\text { cytoskeletal protein } \\
\end{array}$ \\
\hline P00973 & OAS1 & $\begin{array}{l}\text { 2'-5'-oligoadenylate synthase } 1 \\
\text { OAS1 } \\
\text { ortholog }\end{array}$ & $\begin{array}{l}\text { 2'-5'-OLIGOADENYLATE } \\
\text { SYNTHASE } 1 \\
\text { (PTHR11258:SF13) }\end{array}$ & nucleotidyltransferase \\
\hline Q9UID6 & ZNF639 & $\begin{array}{l}\text { Zinc finger protein } 639 \\
\text { ZNF639 } \\
\text { ortholog }\end{array}$ & $\begin{array}{l}\text { ZINC FINGER PROTEIN } 639 \\
\text { (PTHR24404:SF35) }\end{array}$ & $\begin{array}{l}\mathrm{C} 2 \mathrm{H} 2 \text { zinc finger } \\
\text { transcription factor }\end{array}$ \\
\hline P11940 & PABPC1 & $\begin{array}{l}\text { Polyadenylate-binding protein } 1 \\
\text { PABPC1 } \\
\text { ortholog }\end{array}$ & $\begin{array}{l}\text { POLYADENYLATE-BINDING } \\
\text { PROTEIN } 1 \\
\text { (PTHR24012:SF409) }\end{array}$ & - \\
\hline
\end{tabular}




\begin{tabular}{|c|c|c|c|c|}
\hline Q5D1E8 & $\mathrm{ZC} 3 \mathrm{H} 12 \mathrm{~A}$ & $\begin{array}{l}\text { Endoribonuclease ZC3H12A } \\
\text { ZC3H12A } \\
\text { ortholog }\end{array}$ & $\begin{array}{l}\text { ENDORIBONUCLEASE } \\
\text { ZC3H12A (PTHR12876:SF10) }\end{array}$ & endoribonuclease \\
\hline O15304 & SIVA1 & $\begin{array}{l}\text { Apoptosis regulatory protein Siva } \\
\text { SIVA1 } \\
\text { ortholog }\end{array}$ & $\begin{array}{l}\text { APOPTOSIS REGULATORY } \\
\text { PROTEIN SIVA } \\
\text { (PTHR14365:SF1) }\end{array}$ & - \\
\hline O95484 & CLDN9 & $\begin{array}{l}\text { Claudin-9 } \\
\text { CLDN9 } \\
\text { ortholog }\end{array}$ & CLAUDIN-9 (PTHR12002:SF42) & tight junction \\
\hline O15393 & TMPRSS2 & $\begin{array}{l}\text { Transmembrane protease serine } 2 \\
\text { TMPRSS2 } \\
\text { ortholog }\end{array}$ & $\begin{array}{l}\text { TRANSMEMBRANE } \\
\text { PROTEASE SERINE } 2 \\
\text { (PTHR24253:SF89) }\end{array}$ & serine protease \\
\hline Q96F44 & TRIM11 & $\begin{array}{l}\text { E3 ubiquitin-protein ligase } \\
\text { TRIM11 } \\
\text { TRIM11 } \\
\text { ortholog }\end{array}$ & $\begin{array}{l}\text { E3 UBIQUITIN-PROTEIN } \\
\text { LIGASE TRIM11 } \\
\text { (PTHR24103:SF648) }\end{array}$ & ubiquitin-protein ligase \\
\hline P38567 & HYAL3 & $\begin{array}{l}\text { Hyaluronidase PH-20 } \\
\text { SPAM1 } \\
\text { ortholog }\end{array}$ & $\begin{array}{l}\text { HYALURONIDASE PH-20 } \\
\text { (PTHR11769:SF20) }\end{array}$ & glycosidase \\
\hline Q10586 & DBP & $\begin{array}{l}\text { D site-binding protein } \\
\text { DBP } \\
\text { ortholog }\end{array}$ & $\begin{array}{l}\text { D SITE-BINDING PROTEIN } \\
\text { (PTHR11988:SF7) }\end{array}$ & $\begin{array}{l}\text { basic leucine zipper } \\
\text { transcription factor }\end{array}$ \\
\hline P05161 & ISG15 & $\begin{array}{l}\text { Ubiquitin-like protein ISG15 } \\
\text { ISG15 } \\
\text { ortholog }\end{array}$ & $\begin{array}{l}\text { UBIQUITIN-LIKE PROTEIN } \\
\text { ISG15 (PTHR10666:SF267) }\end{array}$ & - \\
\hline Q676U5 & ATG16L1 & $\begin{array}{l}\text { Autophagy-related protein 16-1 } \\
\text { ATG16L1 } \\
\text { ortholog }\end{array}$ & $\begin{array}{l}\text { AUTOPHAGY-RELATED } \\
\text { PROTEIN 16-1 } \\
\text { (PTHR19878:SF6) }\end{array}$ & - \\
\hline P29728 & OAS2 & $\begin{array}{l}\text { 2'-5'-oligoadenylate synthase } 2 \\
\text { OAS2 } \\
\text { ortholog }\end{array}$ & $\begin{array}{l}\text { 2'-5'-OLIGOADENYLATE } \\
\text { SYNTHASE } 2 \\
\text { (PTHR11258:SF3) }\end{array}$ & nucleotidyltransferase \\
\hline Q9BRG2 & SH2D3A & $\begin{array}{l}\text { SH2 domain-containing protein } \\
\text { 3A } \\
\text { SH2D3A } \\
\text { ortholog }\end{array}$ & $\begin{array}{l}\text { SH2 DOMAIN-CONTAINING } \\
\text { PROTEIN 3A } \\
\text { (PTHR14247:SF11) }\end{array}$ & - \\
\hline P42566 & EPS15 & $\begin{array}{l}\text { Epidermal growth factor receptor } \\
\text { substrate } 15 \\
\text { EPS15 } \\
\text { ortholog }\end{array}$ & $\begin{array}{l}\text { EPIDERMAL GROWTH } \\
\text { FACTOR RECEPTOR } \\
\text { SUBSTRATE 15 } \\
\text { (PTHR11216:SF54) }\end{array}$ & membrane traffic protein \\
\hline P26022 & PTX3 & $\begin{array}{l}\text { Pentraxin-related protein PTX3 } \\
\text { PTX3 } \\
\text { ortholog }\end{array}$ & $\begin{array}{l}\text { PENTRAXIN-RELATED } \\
\text { PROTEIN PTX3 } \\
\text { (PTHR46943:SF1) }\end{array}$ & - \\
\hline O00308 & WWP2 & $\begin{array}{l}\text { NEDD4-like E3 ubiquitin-protein } \\
\text { ligase WWP2 } \\
\text { WWP2 } \\
\text { ortholog }\end{array}$ & $\begin{array}{l}\text { NEDD4-LIKE E3 UBIQUITIN- } \\
\text { PROTEIN LIGASE WWP2 } \\
\text { (PTHR11254:SF396) }\end{array}$ & ubiquitin-protein ligase \\
\hline Q05823 & RNASEL & $\begin{array}{l}\text { 2-5A-dependent ribonuclease } \\
\text { RNASEL } \\
\text { ortholog }\end{array}$ & $\begin{array}{l}\text { 2-5A-DEPENDENT } \\
\text { RIBONUCLEASE } \\
\text { (PTHR24141:SF1) }\end{array}$ & - \\
\hline P49790 & NUP153 & $\begin{array}{l}\text { Nuclear pore complex protein } \\
\text { Nup153 } \\
\text { NUP153 } \\
\text { ortholog }\end{array}$ & $\begin{array}{l}\text { NUCLEAR PORE COMPLEX } \\
\text { PROTEIN NUP153 } \\
\text { (PTHR23193:SF23) }\end{array}$ & transporter \\
\hline $\mathrm{P} 12821$ & $\mathrm{ACE}$ & $\begin{array}{l}\text { Angiotensin-converting enzyme } \\
\text { ACE } \\
\text { ortholog }\end{array}$ & $\begin{array}{l}\text { ANGIOTENSIN-CONVERTING } \\
\text { ENZYME (PTHR10514:SF25) }\end{array}$ & metalloprotease \\
\hline Q15768 & EFNB3 & $\begin{array}{l}\text { Ephrin-B3 } \\
\text { EFNB3 } \\
\text { ortholog }\end{array}$ & EPHRIN-B3 (PTHR11304:SF34) & $\begin{array}{l}\text { membrane-bound } \\
\text { signaling molecule }\end{array}$ \\
\hline
\end{tabular}




\begin{tabular}{|c|c|c|c|c|}
\hline Q16666 & IFI16 & $\begin{array}{l}\text { Gamma-interferon-inducible } \\
\text { protein } 16 \\
\text { IFI16 } \\
\text { ortholog }\end{array}$ & $\begin{array}{l}\text { GAMMA-INTERFERON- } \\
\text { INDUCIBLE PROTEIN } 16 \\
\text { (PTHR12200:SF5) }\end{array}$ & $\begin{array}{l}\text { DNA-binding } \\
\text { transcription factor }\end{array}$ \\
\hline Q99816 & TSG101 & $\begin{array}{l}\text { Tumor susceptibility gene } 101 \\
\text { protein } \\
\text { TSG101 } \\
\text { ortholog }\end{array}$ & $\begin{array}{l}\text { TUMOR SUSCEPTIBILITY } \\
\text { GENE 101 PROTEIN } \\
\text { (PTHR23306:SF17) }\end{array}$ & ubiquitin-protein ligase \\
\hline Q9Y624 & F11R & $\begin{array}{l}\text { Junctional adhesion molecule A } \\
\text { F11R } \\
\text { ortholog }\end{array}$ & $\begin{array}{l}\text { JUNCTIONAL ADHESION } \\
\text { MOLECULE A } \\
\text { (PTHR45113:SF1) }\end{array}$ & - \\
\hline P17844 & DDX5 & $\begin{array}{l}\text { Probable ATP-dependent RNA } \\
\text { helicase DDX5 } \\
\text { DDX5 } \\
\text { ortholog }\end{array}$ & $\begin{array}{l}\text { ATP-DEPENDENT RNA } \\
\text { HELICASE DDX5-RELATED } \\
\text { (PTHR47958:SF90) }\end{array}$ & - \\
\hline P52948 & NUP98 & $\begin{array}{l}\text { Nuclear pore complex protein } \\
\text { Nup98-Nup96 } \\
\text { NUP98 } \\
\text { ortholog }\end{array}$ & $\begin{array}{l}\text { NUCLEAR PORE COMPLEX } \\
\text { PROTEIN NUP98-NUP96 } \\
\text { (PTHR23198:SF17) }\end{array}$ & transporter \\
\hline P20591 & MX1 & $\begin{array}{l}\text { Interferon-induced GTP-binding } \\
\text { protein Mx1 } \\
\text { MX1 } \\
\text { ortholog }\end{array}$ & $\begin{array}{l}\text { INTERFERON-INDUCED GTP- } \\
\text { BINDING PROTEIN MX1 } \\
\text { (PTHR11566:SF51) }\end{array}$ & membrane traffic protein \\
\hline Q13114 & TRAF3 & $\begin{array}{l}\text { TNF receptor-associated factor } 3 \\
\text { TRAF3 } \\
\text { ortholog }\end{array}$ & $\begin{array}{l}\text { TNF RECEPTOR- } \\
\text { ASSOCIATED FACTOR } 3 \\
\text { (PTHR10131:SF76) }\end{array}$ & scaffold/adaptor protein \\
\hline P28223 & HTR2A & $\begin{array}{l}\text { 5-hydroxytryptamine receptor } 2 \mathrm{~A} \\
\text { HTR2A } \\
\text { ortholog }\end{array}$ & $\begin{array}{l}\text { 5-HYDROXYTRYPTAMINE } \\
\text { RECEPTOR 2A } \\
\text { (PTHR24247:SF30) }\end{array}$ & $\begin{array}{l}\text { G-protein coupled } \\
\text { receptor }\end{array}$ \\
\hline Q8IUH3 & RBM45 & $\begin{array}{l}\text { RNA-binding protein } 45 \\
\text { RBM45 } \\
\text { ortholog }\end{array}$ & $\begin{array}{l}\text { RNA-BINDING PROTEIN } 45 \\
\text { (PTHR24012:SF812) }\end{array}$ & - \\
\hline Q9NV58 & RNF19A & $\begin{array}{l}\text { E3 ubiquitin-protein ligase } \\
\text { RNF19A } \\
\text { RNF19A } \\
\text { ortholog }\end{array}$ & $\begin{array}{l}\text { E3 UBIQUITIN-PROTEIN } \\
\text { LIGASE RNF19A } \\
\text { (PTHR11685:SF111) }\end{array}$ & ubiquitin-protein ligase \\
\hline Q15223 & NECTIN1 & $\begin{array}{l}\text { Nectin-1 } \\
\text { NECTIN1 } \\
\text { ortholog }\end{array}$ & NECTIN-1 (PTHR23277:SF69) & - \\
\hline Q31612 & HLA-B & $\begin{array}{l}\text { HLA class I histocompatibility } \\
\text { antigen, B-73 alpha chain } \\
\text { HLA-B } \\
\text { ortholog }\end{array}$ & $\begin{array}{l}\text { HLA CLASS I } \\
\text { HISTOCOMPATIBILITY } \\
\text { ANTIGEN, B-73 ALPHA } \\
\text { CHAIN (PTHR16675:SF186) }\end{array}$ & - \\
\hline Q01628 & IFITM3 & $\begin{array}{l}\text { Interferon-induced } \\
\text { transmembrane protein } 3 \\
\text { IFITM3 } \\
\text { ortholog }\end{array}$ & $\begin{array}{l}\text { INTERFERON-INDUCED } \\
\text { TRANSMEMBRANE PROTEIN } \\
3 \text { (PTHR13999:SF4) }\end{array}$ & - \\
\hline P52799 & EFNB2 & $\begin{array}{l}\text { Ephrin-B2 } \\
\text { EFNB2 } \\
\text { ortholog }\end{array}$ & EPHRIN-B2 (PTHR11304:SF18) & $\begin{array}{l}\text { membrane-bound } \\
\text { signaling molecule }\end{array}$ \\
\hline $\mathrm{P} 08174$ & CD55 & $\begin{array}{l}\text { Complement decay-accelerating } \\
\text { factor } \\
\text { CD55 } \\
\text { ortholog }\end{array}$ & $\begin{array}{l}\text { COMPLEMENT DECAY- } \\
\text { ACCELERATING FACTOR } \\
\text { (PTHR19325:SF317) }\end{array}$ & - \\
\hline P51681 & CCR5 & $\begin{array}{l}\text { C-C chemokine receptor type } 5 \\
\text { CCR5 } \\
\text { ortholog }\end{array}$ & $\begin{array}{l}\text { C-C CHEMOKINE RECEPTOR } \\
\text { TYPE } 5 \text { (PTHR10489:SF686) }\end{array}$ & - \\
\hline P78362 & SRPK2 & $\begin{array}{l}\text { SRSF protein kinase } 2 \\
\text { SRPK2 }\end{array}$ & $\begin{array}{l}\text { SRSF PROTEIN KINASE } 2 \\
\text { (PTHR24055:SF102) }\end{array}$ & $\begin{array}{l}\text { non-receptor } \\
\text { serine/threonine protein }\end{array}$ \\
\hline
\end{tabular}




\begin{tabular}{|c|c|c|c|c|}
\hline & & ortholog & & kinase \\
\hline Q9H0U4 & RAB1B & $\begin{array}{l}\text { Ras-related protein Rab-1B } \\
\text { RAB1B } \\
\text { ortholog }\end{array}$ & $\begin{array}{l}\text { RAS-RELATED PROTEIN } \\
\text { RAB-1B (PTHR24073:SF1096) }\end{array}$ & - \\
\hline P37198 & NUP62 & $\begin{array}{l}\text { Nuclear pore glycoprotein p62 } \\
\text { NUP62 } \\
\text { ortholog }\end{array}$ & $\begin{array}{l}\text { NUCLEAR PORE } \\
\text { GLYCOPROTEIN P62 } \\
\text { (PTHR12084:SF12) }\end{array}$ & transporter \\
\hline $\mathrm{P} 42701$ & IL12RB1 & $\begin{array}{l}\text { Interleukin-12 receptor subunit } \\
\text { beta-1 } \\
\text { IL12RB1 } \\
\text { ortholog }\end{array}$ & $\begin{array}{l}\text { INTERLEUKIN-12 RECEPTOR } \\
\text { SUBUNIT BETA-1 } \\
\text { (PTHR23036:SF51) }\end{array}$ & cytokine \\
\hline P0DMV8 & HSPA1A & $\begin{array}{l}\text { Heat shock } 70 \mathrm{kDa} \text { protein } 1 \mathrm{~A} \\
\text { HSPA1A } \\
\text { ortholog }\end{array}$ & $\begin{array}{l}\text { HEAT SHOCK } 70 \text { KDA } \\
\text { PROTEIN 1A-RELATED } \\
\text { (PTHR19375:SF223) }\end{array}$ & - \\
\hline P01375 & TNF & $\begin{array}{l}\text { Tumor necrosis factor } \\
\text { TNF } \\
\text { ortholog }\end{array}$ & $\begin{array}{l}\text { TUMOR NECROSIS FACTOR } \\
\text { (PTHR11471:SF23) }\end{array}$ & - \\
\hline Q12899 & TRIM26 & $\begin{array}{l}\text { Tripartite motif-containing } \\
\text { protein } 26 \\
\text { TRIM26 } \\
\text { ortholog }\end{array}$ & $\begin{array}{l}\text { TRIPARTITE MOTIF- } \\
\text { CONTAINING PROTEIN } 26 \\
\text { (PTHR24103:SF369) }\end{array}$ & ubiquitin-protein ligase \\
\hline P00533 & EGFR & $\begin{array}{l}\text { Epidermal growth factor receptor } \\
\text { EGFR } \\
\text { ortholog }\end{array}$ & $\begin{array}{l}\text { EPIDERMAL GROWTH } \\
\text { FACTOR RECEPTOR } \\
\text { (PTHR24416:SF91) } \\
\end{array}$ & - \\
\hline Q07817 & BCL2L1 & $\begin{array}{l}\text { Bcl-2-like protein } 1 \\
\text { BCL2L1 } \\
\text { ortholog }\end{array}$ & $\begin{array}{l}\text { BCL-2-LIKE PROTEIN } 1 \\
\text { (PTHR11256:SF12) }\end{array}$ & - \\
\hline P80075 & CCL8 & $\begin{array}{l}\text { C-C motif chemokine } 8 \\
\text { CCL8 } \\
\text { ortholog }\end{array}$ & $\begin{array}{l}\text { C-C MOTIF CHEMOKINE } 8 \\
\text { (PTHR12015:SF168) }\end{array}$ & cytokine \\
\hline O95832 & CLDN1 & $\begin{array}{l}\text { Claudin-1 } \\
\text { CLDN1 } \\
\text { ortholog } \\
\end{array}$ & CLAUDIN-1 (PTHR12002:SF92) & tight junction \\
\hline $\mathrm{P} 07858$ & CTSB & $\begin{array}{l}\text { Cathepsin B } \\
\text { CTSB } \\
\text { ortholog }\end{array}$ & $\begin{array}{l}\text { CATHEPSIN B } \\
\text { (PTHR12411:SF714) }\end{array}$ & cysteine protease \\
\hline O00602 & FCN1 & $\begin{array}{l}\text { Ficolin-1 } \\
\text { FCN1 } \\
\text { ortholog }\end{array}$ & $\begin{array}{l}\text { FICOLIN-1-RELATED } \\
\text { (PTHR19143:SF346) }\end{array}$ & $\begin{array}{l}\text { intercellular signal } \\
\text { molecule }\end{array}$ \\
\hline Q9NWF4 & SLC52A1 & $\begin{array}{l}\text { Solute carrier family } 52 \text {, } \\
\text { riboflavin transporter, member } 1 \\
\text { SLC52A1 } \\
\text { ortholog }\end{array}$ & $\begin{array}{l}\text { SOLUTE CARRIER FAMILY } \\
\text { 52, RIBOFLAVIN } \\
\text { TRANSPORTER, MEMBER } 1 \\
\text { (PTHR12929:SF1) } \\
\end{array}$ & $\begin{array}{l}\text { secondary carrier } \\
\text { transporter }\end{array}$ \\
\hline Q9HAB3 & SLC52A2 & $\begin{array}{l}\text { Solute carrier family } 52, \\
\text { riboflavin transporter, member } 2 \\
\text { SLC52A2 } \\
\text { ortholog }\end{array}$ & $\begin{array}{l}\text { SOLUTE CARRIER FAMILY } \\
\text { 52, RIBOFLAVIN } \\
\text { TRANSPORTER, MEMBER } 2 \\
\text { (PTHR12929:SF17) }\end{array}$ & $\begin{array}{l}\text { secondary carrier } \\
\text { transporter }\end{array}$ \\
\hline O00592 & $\mathrm{PC}$ & $\begin{array}{l}\text { Podocalyxin } \\
\text { PODXL } \\
\text { ortholog }\end{array}$ & $\begin{array}{l}\text { PODOCALYXIN } \\
\text { (PTHR12067:SF5) }\end{array}$ & cell adhesion molecule \\
\hline P25098 & GRK2 & $\begin{array}{l}\text { Beta-adrenergic receptor kinase } 1 \\
\text { GRK2 } \\
\text { ortholog }\end{array}$ & $\begin{array}{l}\text { BETA-ADRENERGIC } \\
\text { RECEPTOR KINASE } 1 \\
\text { (PTHR24355:SF22) } \\
\end{array}$ & $\begin{array}{l}\text { non-receptor } \\
\text { serine/threonine protein } \\
\text { kinase }\end{array}$ \\
\hline P20023 & CR2 & $\begin{array}{l}\text { Complement receptor type } 2 \\
\text { CR2 } \\
\text { ortholog }\end{array}$ & $\begin{array}{l}\text { COMPLEMENT RECEPTOR } \\
\text { TYPE } 2 \text { (PTHR19325:SF391) }\end{array}$ & - \\
\hline $\mathrm{P} 14735$ & IDE & $\begin{array}{l}\text { Insulin-degrading enzyme } \\
\text { IDE } \\
\text { ortholog }\end{array}$ & $\begin{array}{l}\text { INSULIN-DEGRADING } \\
\text { ENZYME-RELATED } \\
\text { (PTHR43690:SF18) }\end{array}$ & metalloprotease \\
\hline
\end{tabular}




\begin{tabular}{|c|c|c|c|c|}
\hline O43820 & HYAL3 & $\begin{array}{l}\text { Hyaluronidase-3 } \\
\text { HYAL3 } \\
\text { ortholog }\end{array}$ & $\begin{array}{l}\text { HYALURONIDASE-3 } \\
\text { (PTHR11769:SF19) }\end{array}$ & glycosidase \\
\hline O00574 & CXCR6 & $\begin{array}{l}\text { C-X-C chemokine receptor type } 6 \\
\text { CXCR6 } \\
\text { ortholog }\end{array}$ & $\begin{array}{l}\text { C-X-C CHEMOKINE } \\
\text { RECEPTOR TYPE } 6 \\
\text { (PTHR10489:SF705) }\end{array}$ & - \\
\hline P09914 & IFIT1 & $\begin{array}{l}\text { Interferon-induced protein with } \\
\text { tetratricopeptide repeats } 1 \\
\text { IFIT1 } \\
\text { ortholog }\end{array}$ & $\begin{array}{l}\text { INTERFERON-INDUCED } \\
\text { PROTEIN WITH } \\
\text { TETRATRICOPEPTIDE } \\
\text { REPEATS } 1 \text { (PTHR10271:SF30) }\end{array}$ & - \\
\hline P30411 & BDKRB2 & $\begin{array}{l}\text { B2 bradykinin receptor } \\
\text { BDKRB2 } \\
\text { ortholog }\end{array}$ & $\begin{array}{l}\text { B2 BRADYKININ RECEPTOR } \\
\text { (PTHR24228:SF25) }\end{array}$ & $\begin{array}{l}\text { G-protein coupled } \\
\text { receptor }\end{array}$ \\
\hline P02810 & PA & $\begin{array}{l}\text { Salivary acidic proline-rich } \\
\text { phosphoprotein } 1 / 2 \\
\text { PRH2 } \\
\text { ortholog }\end{array}$ & $\begin{array}{l}\text { SALIVARY ACIDIC PROLINE- } \\
\text { RICH PHOSPHOPROTEIN 1/2 } \\
\text { (PTHR23203:SF16) }\end{array}$ & $\begin{array}{l}\text { antimicrobial response } \\
\text { protein }\end{array}$ \\
\hline Q99549 & $\begin{array}{l}\text { MPHOSP } \\
\text { H8 }\end{array}$ & $\begin{array}{l}\text { M-phase phosphoprotein } 8 \\
\text { MPHOSPH8 } \\
\text { ortholog }\end{array}$ & $\begin{array}{l}\text { M-PHASE PHOSPHOPROTEIN } \\
8 \text { (PTHR24166:SF47) }\end{array}$ & - \\
\hline P61073 & CXCR4 & $\begin{array}{l}\text { C-X-C chemokine receptor type } 4 \\
\text { CXCR } 4 \\
\text { ortholog }\end{array}$ & $\begin{array}{l}\text { C-X-C CHEMOKINE } \\
\text { RECEPTOR TYPE } 4 \\
\text { (PTHR10489:SF594) }\end{array}$ & - \\
\hline P01574 & IFNB1 & $\begin{array}{l}\text { Interferon beta } \\
\text { IFNB1 } \\
\text { ortholog }\end{array}$ & $\begin{array}{l}\text { INTERFERON BETA } \\
\text { (PTHR11691:SF68) }\end{array}$ & - \\
\hline $\mathrm{P} 07711$ & CTSL & $\begin{array}{l}\text { Cathepsin L1 } \\
\text { CTSL } \\
\text { ortholog }\end{array}$ & $\begin{array}{l}\text { CATHEPSIN L1 } \\
\text { (PTHR12411:SF57) }\end{array}$ & cysteine protease \\
\hline Q9H0M0 & WWP1 & $\begin{array}{l}\text { NEDD4-like E3 ubiquitin-protein } \\
\text { ligase WWP1 } \\
\text { WWP1 } \\
\text { ortholog }\end{array}$ & $\begin{array}{l}\text { NEDD4-LIKE E3 UBIQUITIN- } \\
\text { PROTEIN LIGASE WWP1 } \\
\text { (PTHR11254:SF299) }\end{array}$ & ubiquitin-protein ligase \\
\hline Q08357 & SLC20A2 & $\begin{array}{l}\text { Sodium-dependent phosphate } \\
\text { transporter } 2 \\
\text { SLC20A2 } \\
\text { ortholog }\end{array}$ & $\begin{array}{l}\text { SODIUM-DEPENDENT } \\
\text { PHOSPHATE TRANSPORTER } \\
2 \text { (PTHR11101:SF83) }\end{array}$ & transporter \\
\hline Q15758 & SLC1A5 & $\begin{array}{l}\text { Neutral amino acid transporter } \\
\text { B(0) } \\
\text { SLC1A5 } \\
\text { ortholog }\end{array}$ & $\begin{array}{l}\text { NEUTRAL AMINO ACID } \\
\text { TRANSPORTER B(0) } \\
\text { (PTHR11958:SF19) }\end{array}$ & $\begin{array}{l}\text { primary active } \\
\text { transporter }\end{array}$ \\
\hline P62820 & RAB1A & $\begin{array}{l}\text { Ras-related protein Rab-1A } \\
\text { RAB1A } \\
\text { ortholog }\end{array}$ & $\begin{array}{l}\text { RAS-RELATED PROTEIN } \\
\text { RAB-1A (PTHR24073:SF963) }\end{array}$ & - \\
\hline Q9P2K8 & EIF2AK4 & $\begin{array}{l}\text { eIF-2-alpha kinase GCN2 } \\
\text { EIF2AK4 } \\
\text { ortholog }\end{array}$ & $\begin{array}{l}\text { EIF-2-ALPHA KINASE GCN2 } \\
\text { (PTHR11042:SF164) }\end{array}$ & $\begin{array}{l}\text { non-receptor } \\
\text { serine/threonine protein } \\
\text { kinase }\end{array}$ \\
\hline P02649 & APOE & $\begin{array}{l}\text { Apolipoprotein E } \\
\text { APOE } \\
\text { ortholog }\end{array}$ & $\begin{array}{l}\text { APOLIPOPROTEIN E } \\
\text { (PTHR18976:SF2) }\end{array}$ & - \\
\hline P60953 & $\mathrm{CDC} 42$ & $\begin{array}{l}\text { Cell division control protein } 42 \\
\text { homolog } \\
\text { CDC42 } \\
\text { ortholog }\end{array}$ & $\begin{array}{l}\text { CELL DIVISION CONTROL } \\
\text { PROTEIN } 42 \text { HOMOLOG } \\
\text { (PTHR24072:SF136) }\end{array}$ & small GTPase \\
\hline O00482 & NR5A2 & $\begin{array}{l}\text { Nuclear receptor subfamily } 5 \\
\text { group A member } 2 \\
\text { NR5A2 } \\
\text { ortholog }\end{array}$ & $\begin{array}{l}\text { NUCLEAR RECEPTOR } \\
\text { SUBFAMILY } 5 \text { GROUP A } \\
\text { MEMBER } 2 \text { (PTHR24086:SF18) }\end{array}$ & $\begin{array}{l}\mathrm{C} 4 \text { zinc finger nuclear } \\
\text { receptor }\end{array}$ \\
\hline O00187 & MASP2 & Mannan-binding lectin serine & MANNAN-BINDING LECTIN & serine protease \\
\hline
\end{tabular}




\begin{tabular}{|c|c|c|c|c|}
\hline & & $\begin{array}{l}\text { protease } 2 \\
\text { MASP2 } \\
\text { ortholog }\end{array}$ & $\begin{array}{l}\text { SERINE PROTEASE } 2 \\
\text { (PTHR24255:SF10) }\end{array}$ & \\
\hline P01730 & CD4 & $\begin{array}{l}\text { T-cell surface glycoprotein CD4 } \\
\text { CD4 } \\
\text { ortholog }\end{array}$ & $\begin{array}{l}\text { T-CELL SURFACE } \\
\text { GLYCOPROTEIN CD4 } \\
\text { (PTHR11422:SF0) }\end{array}$ & - \\
\hline $\mathrm{P} 04233$ & CD74 & $\begin{array}{l}\text { HLA class II histocompatibility } \\
\text { antigen gamma chain } \\
\text { CD74 } \\
\text { ortholog }\end{array}$ & $\begin{array}{l}\text { HLA CLASS II } \\
\text { HISTOCOMPATIBILITY } \\
\text { ANTIGEN GAMMA CHAIN } \\
\text { (PTHR14093:SF17) }\end{array}$ & scaffold/adaptor protein \\
\hline Q9BYF1 & ACE2 & $\begin{array}{l}\text { Angiotensin-converting enzyme } 2 \\
\text { ACE2 } \\
\text { ortholog }\end{array}$ & $\begin{array}{l}\text { ANGIOTENSIN-CONVERTING } \\
\text { ENZYME } 2 \text { (PTHR10514:SF24) }\end{array}$ & metalloprotease \\
\hline P57740 & NUP107 & $\begin{array}{l}\text { Nuclear pore complex protein } \\
\text { Nup107 } \\
\text { NUP107 } \\
\text { ortholog }\end{array}$ & $\begin{array}{l}\text { NUCLEAR PORE COMPLEX } \\
\text { PROTEIN NUP107 } \\
\text { (PTHR13003:SF2) }\end{array}$ & transporter \\
\hline Q03135 & CAV1 & $\begin{array}{l}\text { Caveolin-1 } \\
\text { CAV1 } \\
\text { ortholog }\end{array}$ & $\begin{array}{l}\text { CAVEOLIN-1 } \\
\text { (PTHR10844:SF18) }\end{array}$ & scaffold/adaptor protein \\
\hline O00635 & TRIM38 & $\begin{array}{l}\text { E3 ubiquitin-protein ligase } \\
\text { TRIM38 } \\
\text { TRIM38 } \\
\text { ortholog }\end{array}$ & $\begin{array}{l}\text { E3 UBIQUITIN-PROTEIN } \\
\text { LIGASE TRIM38 } \\
\text { (PTHR24103:SF47) }\end{array}$ & ubiquitin-protein ligase \\
\hline P03973 & SLPI & $\begin{array}{l}\text { Antileukoproteinase } \\
\text { SLPI } \\
\text { ortholog }\end{array}$ & $\begin{array}{l}\text { ANTILEUKOPROTEINASE } \\
\text { (PTHR19441:SF44) }\end{array}$ & protease inhibitor \\
\hline $\mathrm{P} 02743$ & APCS & $\begin{array}{l}\text { Serum amyloid P-component } \\
\text { APCS } \\
\text { ortholog }\end{array}$ & $\begin{array}{l}\text { SERUM AMYLOID P- } \\
\text { COMPONENT } \\
\text { (PTHR45869:SF5) }\end{array}$ & - \\
\hline Q15075 & EEA1 & $\begin{array}{l}\text { Early endosome antigen } 1 \\
\text { EEA1 } \\
\text { ortholog }\end{array}$ & $\begin{array}{l}\text { EARLY ENDOSOME } \\
\text { ANTIGEN } 1 \text { (PTHR23164:SF17) }\end{array}$ & $\begin{array}{l}\text { membrane trafficking } \\
\text { regulatory protein }\end{array}$ \\
\hline Q9Y2S7 & POLDIP2 & $\begin{array}{l}\text { Polymerase delta-interacting } \\
\text { protein } 2 \\
\text { POLDIP2 } \\
\text { ortholog }\end{array}$ & $\begin{array}{l}\text { POLYMERASE DELTA- } \\
\text { INTERACTING PROTEIN } 2 \\
\text { (PTHR14289:SF16) }\end{array}$ & - \\
\hline Q14973 & SLC10A1 & $\begin{array}{l}\text { Sodium/bile acid cotransporter } \\
\text { SLC10A1 } \\
\text { ortholog }\end{array}$ & $\begin{array}{l}\text { SODIUM/BILE ACID } \\
\text { COTRANSPORTER } \\
(\text { PTHR10361:SF40) }\end{array}$ & $\begin{array}{l}\text { primary active } \\
\text { transporter }\end{array}$ \\
\hline P10415 & BCL2 & $\begin{array}{l}\text { Apoptosis regulator } \mathrm{Bcl}-2 \\
\text { BCL2 } \\
\text { ortholog }\end{array}$ & $\begin{array}{l}\text { APOPTOSIS REGULATOR } \\
\text { BCL-2 (PTHR11256:SF11) }\end{array}$ & - \\
\hline Q9UL45 & $\mathrm{PA}$ & $\begin{array}{l}\text { Biogenesis of lysosome-related } \\
\text { organelles complex } 1 \text { subunit } 6 \\
\text { BLOC1S6 } \\
\text { ortholog }\end{array}$ & $\begin{array}{l}\text { BIOGENESIS OF LYSOSOME- } \\
\text { RELATED ORGANELLES } \\
\text { COMPLEX 1 SUBUNIT } 6 \\
\text { (PTHR31328:SF2) }\end{array}$ & - \\
\hline Q86U86 & PB1 & $\begin{array}{l}\text { Protein polybromo-1 } \\
\text { PBRM1 } \\
\text { ortholog }\end{array}$ & $\begin{array}{l}\text { PROTEIN POLYBROMO-1 } \\
\text { (PTHR16062:SF15) }\end{array}$ & - \\
\hline P02786 & TFRC & $\begin{array}{l}\text { Transferrin receptor protein } 1 \\
\text { TFRC } \\
\text { ortholog }\end{array}$ & $\begin{array}{l}\text { TRANSFERRIN RECEPTOR } \\
\text { PROTEIN } 1 \text { (PTHR10404:SF26) }\end{array}$ & metalloprotease \\
\hline Q06418 & TYRO3 & $\begin{array}{l}\text { Tyrosine-protein kinase receptor } \\
\text { TYRO3 } \\
\text { TYRO3 } \\
\text { ortholog }\end{array}$ & $\begin{array}{l}\text { TYROSINE-PROTEIN KINASE } \\
\text { RECEPTOR TYRO3 } \\
\text { (PTHR24416:SF279) }\end{array}$ & - \\
\hline P51636 & CAV2 & $\begin{array}{l}\text { Caveolin-2 } \\
\text { CAV2 }\end{array}$ & $\begin{array}{l}\text { CAVEOLIN-2 } \\
\text { (PTHR10844:SF3) }\end{array}$ & scaffold/adaptor protein \\
\hline
\end{tabular}




\begin{tabular}{|c|c|c|c|c|}
\hline & & ortholog & & \\
\hline Q96QI5 & HS3ST5 & $\begin{array}{l}\text { Heparan sulfate glucosamine 3-O- } \\
\text { sulfotransferase } 6 \\
\text { HS3ST6 } \\
\text { ortholog }\end{array}$ & $\begin{array}{l}\text { HEPARAN SULFATE } \\
\text { GLUCOSAMINE 3-O- } \\
\text { SULFOTRANSFERASE } 6 \\
\text { (PTHR10605:SF62) }\end{array}$ & - \\
\hline P26196 & DDX6 & $\begin{array}{l}\text { Probable ATP-dependent RNA } \\
\text { helicase DDX6 } \\
\text { DDX6 } \\
\text { ortholog }\end{array}$ & $\begin{array}{l}\text { ATP-DEPENDENT RNA } \\
\text { HELICASE DDX6-RELATED } \\
\text { (PTHR47960:SF2) }\end{array}$ & - \\
\hline Q92786 & PROX1 & $\begin{array}{l}\text { Prospero homeobox protein } 1 \\
\text { PROX1 } \\
\text { ortholog }\end{array}$ & $\begin{array}{l}\text { PROSPERO HOMEOBOX } \\
\text { PROTEIN } 1 \text { (PTHR12198:SF6) }\end{array}$ & $\begin{array}{l}\text { homeodomain } \\
\text { transcription factor }\end{array}$ \\
\hline Q13155 & AIMP2 & $\begin{array}{l}\text { Aminoacyl tRNA synthase } \\
\text { complex-interacting } \\
\text { multifunctional protein } 2 \\
\text { AIMP2 } \\
\text { ortholog }\end{array}$ & $\begin{array}{l}\text { AMINOACYL TRNA } \\
\text { SYNTHASE COMPLEX- } \\
\text { INTERACTING } \\
\text { MULTIFUNCTIONAL } \\
\text { PROTEIN } 2 \text { (PTHR13438:SF2) }\end{array}$ & scaffold/adaptor protein \\
\hline P01130 & LDLR & $\begin{array}{l}\text { Low-density lipoprotein receptor } \\
\text { LDLR } \\
\text { ortholog }\end{array}$ & $\begin{array}{l}\text { LOW-DENSITY LIPOPROTEIN } \\
\text { RECEPTOR (PTHR24270:SF21) }\end{array}$ & apolipoprotein \\
\hline Q12906 & ILF3 & $\begin{array}{l}\text { Interleukin enhancer-binding } \\
\text { factor } 3 \\
\text { ILF3 } \\
\text { ortholog }\end{array}$ & $\begin{array}{l}\text { INTERLEUKIN ENHANCER- } \\
\text { BINDING FACTOR } 3 \\
\text { (PTHR45762:SF4) }\end{array}$ & RNA binding protein \\
\hline Q9UQF0 & ERVW-1 & $\begin{array}{l}\text { Syncytin-1 } \\
\text { ERVW-1 } \\
\text { ortholog }\end{array}$ & $\begin{array}{l}\text { SYNCYTIN-1 } \\
\text { (PTHR10424:SF48) }\end{array}$ & - \\
\hline P11279 & LAMP1 & $\begin{array}{l}\text { Lysosome-associated membrane } \\
\text { glycoprotein } 1 \\
\text { LAMP1 } \\
\text { ortholog }\end{array}$ & $\begin{array}{l}\text { LYSOSOME-ASSOCIATED } \\
\text { MEMBRANE GLYCOPROTEIN } \\
1 \text { (PTHR11506:SF27) }\end{array}$ & $\begin{array}{l}\text { membrane trafficking } \\
\text { regulatory protein }\end{array}$ \\
\hline O95433 & AHSA1 & $\begin{array}{l}\text { Activator of } 90 \mathrm{kDa} \text { heat shock } \\
\text { protein ATPase homolog } 1 \\
\text { AHSA1 } \\
\text { ortholog }\end{array}$ & $\begin{array}{l}\text { ACTIVATOR OF } 90 \text { KDA } \\
\text { HEAT SHOCK PROTEIN } \\
\text { ATPASE HOMOLOG } 1 \\
\text { (PTHR13009:SF7) }\end{array}$ & chaperone \\
\hline P06493 & CDK1 & $\begin{array}{l}\text { Cyclin-dependent kinase } 1 \\
\text { CDK1 } \\
\text { ortholog }\end{array}$ & $\begin{array}{l}\text { CYCLIN-DEPENDENT } \\
\text { KINASE } 1 \text { (PTHR24056:SF334) }\end{array}$ & $\begin{array}{l}\text { non-receptor } \\
\text { serine/threonine protein } \\
\text { kinase }\end{array}$ \\
\hline Q8WZ33 & MIP & $\begin{array}{l}\text { MaFF-interacting protein } \\
\text { MAFIP } \\
\text { ortholog }\end{array}$ & $\begin{array}{l}\text { MAFF-INTERACTING } \\
\text { PROTEIN-RELATED } \\
\text { (PTHR19960:SF12) }\end{array}$ & $\begin{array}{l}\text { non-motor microtubule } \\
\text { binding protein }\end{array}$ \\
\hline P13500 & CCL2 & $\begin{array}{l}\text { C-C motif chemokine } 2 \\
\text { CCL2 } \\
\text { ortholog }\end{array}$ & $\begin{array}{l}\text { C-C MOTIF CHEMOKINE } 2 \\
\text { (PTHR12015:SF98) }\end{array}$ & cytokine \\
\hline Q96AZ6 & ISG20 & $\begin{array}{l}\text { Interferon-stimulated gene } 20 \\
\text { kDa protein } \\
\text { ISG20 } \\
\text { ortholog }\end{array}$ & $\begin{array}{l}\text { INTERFERON-STIMULATED } \\
\text { GENE } 20 \text { KDA PROTEIN } \\
\text { (PTHR12801:SF59) }\end{array}$ & exoribonuclease \\
\hline $\mathrm{P} 02765$ & AHSG & $\begin{array}{l}\text { Alpha-2-HS-glycoprotein } \\
\text { AHSG } \\
\text { ortholog }\end{array}$ & $\begin{array}{l}\text { ALPHA-2-HS-GLYCOPROTEIN } \\
\text { (PTHR13814:SF6) }\end{array}$ & protease inhibitor \\
\hline Q96NY8 & NECTIN4 & $\begin{array}{l}\text { Nectin-4 } \\
\text { NECTIN4 } \\
\text { ortholog } \\
\end{array}$ & NECTIN-4 (PTHR23277:SF11) & - \\
\hline Q6UWE0 & LRSAM1 & $\begin{array}{l}\text { E3 ubiquitin-protein ligase } \\
\text { LRSAM1 } \\
\text { LRSAM1 } \\
\text { ortholog }\end{array}$ & $\begin{array}{l}\text { E3 UBIQUITIN-PROTEIN } \\
\text { LIGASE LRSAM1 } \\
\text { (PTHR16083:SF5) }\end{array}$ & - \\
\hline P15144 & ANPEP & Aminopeptidase $\mathrm{N}$ & AMINOPEPTIDASE N & metalloprotease \\
\hline
\end{tabular}




\begin{tabular}{|c|c|c|c|c|}
\hline & & $\begin{array}{l}\text { ANPEP } \\
\text { ortholog }\end{array}$ & (PTHR11533:SF172) & \\
\hline Q92956 & $\begin{array}{l}\text { TNFRSF1 } \\
4\end{array}$ & $\begin{array}{l}\text { Tumor necrosis factor receptor } \\
\text { superfamily member } 14 \\
\text { TNFRSF14 } \\
\text { ortholog }\end{array}$ & $\begin{array}{l}\text { TUMOR NECROSIS FACTOR } \\
\text { RECEPTOR SUPERFAMILY } \\
\text { MEMBER } 14 \text { (PTHR46838:SF1) }\end{array}$ & - \\
\hline Q9BVG3 & TRIM62 & $\begin{array}{l}\text { E3 ubiquitin-protein ligase } \\
\text { TRIM62 } \\
\text { TRIM62 } \\
\text { ortholog }\end{array}$ & $\begin{array}{l}\text { E3 UBIQUITIN-PROTEIN } \\
\text { LIGASE TRIM62 } \\
\text { (PTHR24103:SF573) }\end{array}$ & ubiquitin-protein ligase \\
\hline P35659 & DEK & $\begin{array}{l}\text { Protein DEK } \\
\text { DEK } \\
\text { ortholog }\end{array}$ & $\begin{array}{l}\text { PROTEIN DEK } \\
\text { (PTHR13468:SF1) }\end{array}$ & $\begin{array}{l}\text { chromatin/chromatin- } \\
\text { binding, or -regulatory } \\
\text { protein }\end{array}$ \\
\hline Q6UXB4 & CLEC4G & $\begin{array}{l}\text { C-type lectin domain family } 4 \\
\text { member G } \\
\text { CLEC4G } \\
\text { ortholog }\end{array}$ & $\begin{array}{l}\text { C-TYPE LECTIN DOMAIN } \\
\text { FAMILY } 4 \text { MEMBER G } \\
\text { (PTHR22802:SF245) }\end{array}$ & membrane traffic protein \\
\hline P35568 & IRS1 & $\begin{array}{l}\text { Insulin receptor substrate } 1 \\
\text { IRS } 1 \\
\text { ortholog }\end{array}$ & $\begin{array}{l}\text { INSULIN RECEPTOR } \\
\text { SUBSTRATE } 1 \\
\text { (PTHR10614:SF11) } \\
\end{array}$ & - \\
\hline P62937 & PPIA & $\begin{array}{l}\text { Peptidyl-prolyl cis-trans } \\
\text { isomerase A } \\
\text { PPIA } \\
\text { ortholog }\end{array}$ & $\begin{array}{l}\text { PEPTIDYL-PROLYL CIS- } \\
\text { TRANS ISOMERASE A } \\
\text { (PTHR11071:SF490) }\end{array}$ & - \\
\hline Q02880 & TOP2B & $\begin{array}{l}\text { DNA topoisomerase 2-beta } \\
\text { TOP2B } \\
\text { ortholog }\end{array}$ & $\begin{array}{l}\text { DNA TOPOISOMERASE 2- } \\
\text { BETA (PTHR10169:SF36) }\end{array}$ & - \\
\hline P19525 & EIF2AK2 & $\begin{array}{l}\text { Interferon-induced, double- } \\
\text { stranded RNA-activated protein } \\
\text { kinase } \\
\text { EIF2AK2 } \\
\text { ortholog }\end{array}$ & $\begin{array}{l}\text { INTERFERON-INDUCED, } \\
\text { DOUBLE-STRANDED RNA- } \\
\text { ACTIVATED PROTEIN } \\
\text { KINASE (PTHR11042:SF163) }\end{array}$ & $\begin{array}{l}\text { non-receptor } \\
\text { serine/threonine protein } \\
\text { kinase }\end{array}$ \\
\hline Q9UBH6 & XPR1 & $\begin{array}{l}\text { Xenotropic and polytropic } \\
\text { retrovirus receptor } 1 \\
\text { XPR1 } \\
\text { ortholog }\end{array}$ & $\begin{array}{l}\text { XENOTROPIC AND } \\
\text { POLYTROPIC RETROVIRUS } \\
\text { RECEPTOR } 1 \text { (PTHR10783:SF4) }\end{array}$ & $\begin{array}{l}\text { secondary carrier } \\
\text { transporter }\end{array}$ \\
\hline P22301 & IL10 & $\begin{array}{l}\text { Interleukin-10 } \\
\text { IL10 } \\
\text { ortholog }\end{array}$ & 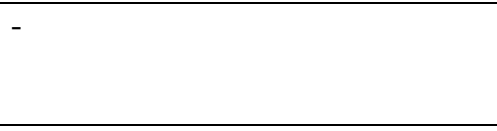 & ( \\
\hline P56747 & CLDN6 & $\begin{array}{l}\text { Claudin-6 } \\
\text { CLDN6 } \\
\text { ortholog }\end{array}$ & CLAUDIN-6 (PTHR12002:SF41) & tight junction \\
\hline Q9H2E6 & SEMA6A & $\begin{array}{l}\text { Semaphorin-6A } \\
\text { SEMA6A } \\
\text { ortholog }\end{array}$ & $\begin{array}{l}\text { SEMAPHORIN-6A } \\
\text { (PTHR11036:SF12) }\end{array}$ & $\begin{array}{l}\text { membrane-bound } \\
\text { signaling molecule }\end{array}$ \\
\hline O95292 & VAPB & $\begin{array}{l}\text { Vesicle-associated membrane } \\
\text { protein-associated protein B/C } \\
\text { VAPB } \\
\text { ortholog }\end{array}$ & $\begin{array}{l}\text { VESICLE-ASSOCIATED } \\
\text { MEMBRANE PROTEIN- } \\
\text { ASSOCIATED PROTEIN B/C } \\
\text { (PTHR10809:SF12) }\end{array}$ & $\begin{array}{l}\text { membrane trafficking } \\
\text { regulatory protein }\end{array}$ \\
\hline Q92824 & PCSK5 & $\begin{array}{l}\text { Proprotein convertase } \\
\text { subtilisin/kexin type } 5 \\
\text { PCSK5 } \\
\text { ortholog }\end{array}$ & $\begin{array}{l}\text { PROPROTEIN CONVERTASE } \\
\text { SUBTILISIN/KEXIN TYPE } 5 \\
\text { (PTHR42884:SF7) }\end{array}$ & serine protease \\
\hline P00491 & NP & $\begin{array}{l}\text { Purine nucleoside phosphorylase } \\
\text { PNP } \\
\text { ortholog }\end{array}$ & $\begin{array}{l}\text { PURINE NUCLEOSIDE } \\
\text { PHOSPHORYLASE } \\
\text { (PTHR11904:SF12) }\end{array}$ & nucleotide kinase \\
\hline $\mathrm{P} 02788$ & LTF & $\begin{array}{l}\text { Lactotransferrin } \\
\text { LTF } \\
\text { ortholog }\end{array}$ & $\begin{array}{l}\text { LACTOTRANSFERRIN } \\
\text { (PTHR11485:SF33) }\end{array}$ & transfer/carrier protein \\
\hline
\end{tabular}




\begin{tabular}{|c|c|c|c|c|}
\hline Q9BV40 & VAMP8 & $\begin{array}{l}\text { Vesicle-associated membrane } \\
\text { protein } 8 \\
\text { VAMP8 } \\
\text { ortholog }\end{array}$ & $\begin{array}{l}\text { VESICLE-ASSOCIATED } \\
\text { MEMBRANE PROTEIN } 8 \\
\text { (PTHR45701:SF7) }\end{array}$ & - \\
\hline Q7Z2W4 & ZC3HAV1 & $\begin{array}{l}\text { Zinc finger CCCH-type antiviral } \\
\text { protein } 1 \\
\text { ZC3HAV1 } \\
\text { ortholog }\end{array}$ & $\begin{array}{l}\text { ZINC FINGER CCCH-TYPE } \\
\text { ANTIVIRAL PROTEIN } 1 \\
\text { (PTHR45740:SF8) }\end{array}$ & - \\
\hline O75791 & GRAP2 & $\begin{array}{l}\text { GRB2-related adapter protein } 2 \\
\text { GRAP2 } \\
\text { ortholog }\end{array}$ & $\begin{array}{l}\text { GRB2-RELATED ADAPTER } \\
\text { PROTEIN } 2 \text { (PTHR46037:SF3) }\end{array}$ & - \\
\hline P04746 & PA & $\begin{array}{l}\text { Pancreatic alpha-amylase } \\
\text { AMY2A } \\
\text { ortholog }\end{array}$ & $\begin{array}{l}\text { ALPHA-AMYLASE 1- } \\
\text { RELATED (PTHR43447:SF27) }\end{array}$ & amylase \\
\hline P01891 & HLA-A & $\begin{array}{l}\text { HLA class I histocompatibility } \\
\text { antigen, A-68 alpha chain } \\
\text { HLA-A } \\
\text { ortholog }\end{array}$ & $\begin{array}{l}\text { HLA CLASS I } \\
\text { HISTOCOMPATIBILITY } \\
\text { ANTIGEN, A-68 ALPHA } \\
\text { CHAIN (PTHR16675:SF229) }\end{array}$ & - \\
\hline Q14393 & GAS6 & $\begin{array}{l}\text { Growth arrest-specific protein } 6 \\
\text { GAS6 } \\
\text { ortholog }\end{array}$ & $\begin{array}{l}\text { GROWTH ARREST-SPECIFIC } \\
\text { PROTEIN } 6 \\
\text { (PTHR24035:SF104) }\end{array}$ & $\begin{array}{l}\text { extracellular matrix } \\
\text { protein }\end{array}$ \\
\hline O60260 & PRKN & $\begin{array}{l}\text { E3 ubiquitin-protein ligase parkin } \\
\text { PRKN } \\
\text { ortholog }\end{array}$ & $\begin{array}{l}\text { E3 UBIQUITIN-PROTEIN } \\
\text { LIGASE PARKIN } \\
\text { (PTHR11685:SF212) }\end{array}$ & ubiquitin-protein ligase \\
\hline Q8WTV0 & SCARB1 & $\begin{array}{l}\text { Scavenger receptor class B } \\
\text { member } 1 \\
\text { SCARB } 1 \\
\text { ortholog }\end{array}$ & $\begin{array}{l}\text { SCAVENGER RECEPTOR } \\
\text { CLASS B MEMBER } 1 \\
\text { (PTHR11923:SF96) }\end{array}$ & $\begin{array}{l}\text { membrane trafficking } \\
\text { regulatory protein }\end{array}$ \\
\hline P13591 & NCAM1 & $\begin{array}{l}\text { Neural cell adhesion molecule } 1 \\
\text { NCAM1 } \\
\text { ortholog }\end{array}$ & $\begin{array}{l}\text { NEURAL CELL ADHESION } \\
\text { MOLECULE } 1 \\
\text { (PTHR12231:SF239) }\end{array}$ & - \\
\hline P46108 & CRK & $\begin{array}{l}\text { Adapter molecule crk } \\
\text { CRK } \\
\text { ortholog }\end{array}$ & $\begin{array}{l}\text { ADAPTER MOLECULE CRK } \\
\text { (PTHR19969:SF8) }\end{array}$ & - \\
\hline O75116 & ROCK2 & $\begin{array}{l}\text { Rho-associated protein kinase } 2 \\
\text { ROCK2 } \\
\text { ortholog }\end{array}$ & $\begin{array}{l}\text { RHO-ASSOCIATED PROTEIN } \\
\text { KINASE } 2 \text { (PTHR22988:SF28) }\end{array}$ & $\begin{array}{l}\text { non-receptor } \\
\text { serine/threonine protein } \\
\text { kinase }\end{array}$ \\
\hline Q9BVP2 & NS & $\begin{array}{l}\text { Guanine nucleotide-binding } \\
\text { protein-like } 3 \\
\text { GNL3 } \\
\text { ortholog }\end{array}$ & $\begin{array}{l}\text { GUANINE NUCLEOTIDE- } \\
\text { BINDING PROTEIN-LIKE } 3 \\
\text { (PTHR11089:SF11) }\end{array}$ & - \\
\hline P01024 & $\mathrm{C} 3$ & $\begin{array}{l}\text { Complement C3 } \\
\text { C3 } \\
\text { ortholog }\end{array}$ & $\begin{array}{l}\text { COMPLEMENT C3 } \\
\text { (PTHR11412:SF81) }\end{array}$ & protease inhibitor \\
\hline P19838 & NFKB1 & $\begin{array}{l}\text { Nuclear factor NF-kappa-B p105 } \\
\text { subunit } \\
\text { NFKB1 } \\
\text { ortholog }\end{array}$ & $\begin{array}{l}\text { NUCLEAR FACTOR NF- } \\
\text { KAPPA-B P105 SUBUNIT } \\
\text { (PTHR24169:SF9) }\end{array}$ & $\begin{array}{l}\text { Rel homology } \\
\text { transcription factor }\end{array}$ \\
\hline$=\mathrm{Q} 15365$ & PCBP1 & $\begin{array}{l}\text { Poly(rC)-binding protein } 1 \\
\text { PCBP1 } \\
\text { ortholog }\end{array}$ & $\begin{array}{l}\text { POLY(RC)-BINDING PROTEIN } \\
1 \text { (PTHR10288:SF96) }\end{array}$ & RNA binding protein \\
\hline P19474 & TRIM21 & $\begin{array}{l}\text { E3 ubiquitin-protein ligase } \\
\text { TRIM21 } \\
\text { TRIM21 } \\
\text { ortholog }\end{array}$ & $\begin{array}{l}\text { E3 UBIQUITIN-PROTEIN } \\
\text { LIGASE TRIM21 } \\
\text { (PTHR24103:SF46) }\end{array}$ & ubiquitin-protein ligase \\
\hline Q16539 & MAPK14 & $\begin{array}{l}\text { Mitogen-activated protein kinase } \\
14 \\
\text { MAPK14 } \\
\text { ortholog }\end{array}$ & $\begin{array}{l}\text { MITOGEN-ACTIVATED } \\
\text { PROTEIN KINASE } 14 \\
\text { (PTHR24055:SF110) }\end{array}$ & $\begin{array}{l}\text { non-receptor } \\
\text { serine/threonine protein } \\
\text { kinase }\end{array}$ \\
\hline
\end{tabular}




\begin{tabular}{|c|c|c|c|c|}
\hline Q01629 & IFITM2 & $\begin{array}{l}\text { Interferon-induced } \\
\text { transmembrane protein } 2 \\
\text { IFITM2 } \\
\text { ortholog }\end{array}$ & $\begin{array}{l}\text { INTERFERON-INDUCED } \\
\text { TRANSMEMBRANE PROTEIN } \\
2 \text { (PTHR13999:SF8) }\end{array}$ & - \\
\hline P09382 & LGALS1 & $\begin{array}{l}\text { Galectin-1 } \\
\text { LGALS1 } \\
\text { ortholog }\end{array}$ & $\begin{array}{l}\text { GALECTIN-1 } \\
\text { (PTHR11346:SF97) }\end{array}$ & $\begin{array}{l}\text { extracellular matrix } \\
\text { protein }\end{array}$ \\
\hline P28482 & MAPK1 & $\begin{array}{l}\text { Mitogen-activated protein kinase } \\
1 \\
\text { MAPK1 } \\
\text { ortholog }\end{array}$ & $\begin{array}{l}\text { MITOGEN-ACTIVATED } \\
\text { PROTEIN KINASE } 1 \\
\text { (PTHR24055:SF203) }\end{array}$ & $\begin{array}{l}\text { non-receptor } \\
\text { serine/threonine protein } \\
\text { kinase }\end{array}$ \\
\hline Q6ZTQ4 & CDHR3 & $\begin{array}{l}\text { Cadherin-related family member } \\
3 \\
\text { CDHR3 } \\
\text { ortholog }\end{array}$ & $\begin{array}{l}\text { CADHERIN-24-RELATED } \\
\text { (PTHR24027:SF272) }\end{array}$ & - \\
\hline P54296 & MYOM2 & $\begin{array}{l}\text { Myomesin-2 } \\
\text { MYOM2 } \\
\text { ortholog }\end{array}$ & $\begin{array}{l}\text { MYOMESIN-2 } \\
\text { (PTHR13817:SF22) }\end{array}$ & - \\
\hline Q06787 & FMR1 & $\begin{array}{l}\text { Synaptic functional regulator } \\
\text { FMR1 } \\
\text { FMR1 } \\
\text { ortholog }\end{array}$ & $\begin{array}{l}\text { SYNAPTIC FUNCTIONAL } \\
\text { REGULATOR FMR1 } \\
\text { (PTHR10603:SF4) }\end{array}$ & translation factor \\
\hline P49685 & GPR15 & $\begin{array}{l}\text { G-protein coupled receptor } 15 \\
\text { GPR15 } \\
\text { ortholog }\end{array}$ & $\begin{array}{l}\text { G-PROTEIN COUPLED } \\
\text { RECEPTOR } 15 \\
\text { (PTHR24228:SF10) }\end{array}$ & $\begin{array}{l}\text { G-protein coupled } \\
\text { receptor }\end{array}$ \\
\hline Q9NRG9 & AAAS & $\begin{array}{l}\text { Aladin } \\
\text { AAAS } \\
\text { ortholog }\end{array}$ & ALADIN (PTHR14494:SF0) & - \\
\hline O95817 & BAG3 & $\begin{array}{l}\text { BAG family molecular chaperone } \\
\text { regulator } 3 \\
\text { BAG3 } \\
\text { ortholog }\end{array}$ & $\begin{array}{l}\text { BAG FAMILY MOLECULAR } \\
\text { CHAPERONE REGULATOR } 3 \\
\text { (PTHR12329:SF12) }\end{array}$ & - \\
\hline P04004 & VTN & $\begin{array}{l}\text { Vitronectin } \\
\text { VTN } \\
\text { ortholog }\end{array}$ & $\begin{array}{l}\text { VITRONECTIN } \\
\text { (PTHR22917:SF3) }\end{array}$ & - \\
\hline P61769 & B2M & $\begin{array}{l}\text { Beta-2-microglobulin } \\
\text { B2M } \\
\text { ortholog }\end{array}$ & $\begin{array}{l}\text { BETA-2-MICROGLOBULIN } \\
\text { (PTHR19944:SF62) }\end{array}$ & $\begin{array}{l}\text { major histocompatibility } \\
\text { complex protein }\end{array}$ \\
\hline Q12891 & HYAL2 & $\begin{array}{l}\text { Hyaluronidase-2 } \\
\text { HYAL2 } \\
\text { ortholog }\end{array}$ & $\begin{array}{l}\text { HYALURONIDASE-2 } \\
\text { (PTHR11769:SF6) }\end{array}$ & glycosidase \\
\hline O15118 & NPC1 & $\begin{array}{l}\text { NPC intracellular cholesterol } \\
\text { transporter } 1 \\
\text { NPC1 } \\
\text { ortholog }\end{array}$ & $\begin{array}{l}\text { NPC INTRACELLULAR } \\
\text { CHOLESTEROL } \\
\text { TRANSPORTER } 1 \\
\text { (PTHR45727:SF2) } \\
\end{array}$ & - \\
\hline Q8IZT8 & HS3ST5 & $\begin{array}{l}\text { Heparan sulfate glucosamine 3-O- } \\
\text { sulfotransferase } 5 \\
\text { HS3ST5 } \\
\text { ortholog }\end{array}$ & $\begin{array}{l}\text { HEPARAN SULFATE } \\
\text { GLUCOSAMINE 3-O- } \\
\text { SULFOTRANSFERASE } 5 \\
\text { (PTHR10605:SF46) }\end{array}$ & - \\
\hline Q9BZY9 & TRIM31 & $\begin{array}{l}\text { E3 ubiquitin-protein ligase } \\
\text { TRIM31 } \\
\text { TRIM31 } \\
\text { ortholog }\end{array}$ & $\begin{array}{l}\text { E3 UBIQUITIN-PROTEIN } \\
\text { LIGASE TRIM31 } \\
\text { (PTHR24103:SF87) }\end{array}$ & ubiquitin-protein ligase \\
\hline Q9UDY6 & TRIM10 & $\begin{array}{l}\text { Tripartite motif-containing } \\
\text { protein } 10 \\
\text { TRIM10 } \\
\text { ortholog }\end{array}$ & $\begin{array}{l}\text { TRIPARTITE MOTIF- } \\
\text { CONTAINING PROTEIN } 10 \\
\text { (PTHR24103:SF329) }\end{array}$ & ubiquitin-protein ligase \\
\hline Q08752 & PPID & $\begin{array}{l}\text { Peptidyl-prolyl cis-trans } \\
\text { isomerase D }\end{array}$ & $\begin{array}{l}\text { PEPTIDYL-PROLYL CIS- } \\
\text { TRANS ISOMERASE D- }\end{array}$ & - \\
\hline
\end{tabular}




\begin{tabular}{|c|c|c|c|c|}
\hline & & $\begin{array}{l}\text { PPID } \\
\text { ortholog }\end{array}$ & RELATED (PTHR11071:SF380) & \\
\hline Q9H1Y0 & ATG5 & $\begin{array}{l}\text { Autophagy protein } 5 \\
\text { ATG5 } \\
\text { ortholog }\end{array}$ & $\begin{array}{l}\text { AUTOPHAGY PROTEIN } 5 \\
\text { (PTHR13040:SF2) }\end{array}$ & $\begin{array}{l}\text { membrane trafficking } \\
\text { regulatory protein }\end{array}$ \\
\hline Q9UQG0 & ERVK-11 & $\begin{array}{l}\text { Endogenous retrovirus group } \mathrm{K} \\
\text { member } 11 \text { Pol protein } \\
\text { ERVK-11 } \\
\text { ortholog }\end{array}$ & $\begin{array}{l}\text { ENDOGENOUS RETROVIRUS } \\
\text { GROUP K MEMBER } 10 \text { POL } \\
\text { PROTEIN-RELATED } \\
\text { (PTHR41694:SF3) }\end{array}$ & - \\
\hline P78536 & ADAM17 & $\begin{array}{l}\text { Disintegrin and metalloproteinase } \\
\text { domain-containing protein } 17 \\
\text { ADAM17 } \\
\text { ortholog }\end{array}$ & $\begin{array}{l}\text { DISINTEGRIN AND } \\
\text { METALLOPROTEINASE } \\
\text { DOMAIN-CONTAINING } \\
\text { PROTEIN } 17 \text { (PTHR45702:SF6) }\end{array}$ & - \\
\hline Q9UGI6 & K3 & $\begin{array}{l}\text { Small conductance calcium- } \\
\text { activated potassium channel } \\
\text { protein } 3 \\
\text { KCNN3 } \\
\text { ortholog }\end{array}$ & $\begin{array}{l}\text { SMALL CONDUCTANCE } \\
\text { CALCIUM-ACTIVATED } \\
\text { POTASSIUM CHANNEL } \\
\text { PROTEIN } 3 \text { (PTHR10153:SF40) }\end{array}$ & $\begin{array}{l}\text { voltage-gated ion } \\
\text { channel }\end{array}$ \\
\hline P05556 & ITGB1 & $\begin{array}{l}\text { Integrin beta-1 } \\
\text { ITGB1 } \\
\text { ortholog }\end{array}$ & $\begin{array}{l}\text { INTEGRIN BETA-1 } \\
\text { (PTHR10082:SF28) }\end{array}$ & cell adhesion molecule \\
\hline P24298 & GPT & $\begin{array}{l}\text { Alanine aminotransferase } 1 \\
\text { GPT } \\
\text { ortholog }\end{array}$ & $\begin{array}{l}\text { ALANINE } \\
\text { AMINOTRANSFERASE } 1 \\
\text { (PTHR11751:SF308) }\end{array}$ & transaminase \\
\hline O43504 & $\begin{array}{l}\text { LAMTOR } \\
\quad 5\end{array}$ & $\begin{array}{l}\text { Ragulator complex protein } \\
\text { LAMTOR5 } \\
\text { LAMTOR5 } \\
\text { ortholog }\end{array}$ & $\begin{array}{l}\text { RAGULATOR COMPLEX } \\
\text { PROTEIN LAMTOR5 } \\
\text { (PTHR13342:SF4) }\end{array}$ & - \\
\hline Q9NPH2 & ISYNA1 & $\begin{array}{l}\text { Inositol-3-phosphate synthase } 1 \\
\text { ISYNA1 } \\
\text { ortholog }\end{array}$ & $\begin{array}{l}\text { INOSITOL-3-PHOSPHATE } \\
\text { SYNTHASE } 1 \\
\text { (PTHR11510:SF5) }\end{array}$ & isomerase \\
\hline Q15517 & CDSN & $\begin{array}{l}\text { Corneodesmosin } \\
\text { CDSN } \\
\text { ortholog }\end{array}$ & $\begin{array}{l}\text { CORNEODESMOSIN } \\
\text { (PTHR23207:SF2) }\end{array}$ & - \\
\hline P56545 & CTBP2 & $\begin{array}{l}\text { C-terminal-binding protein } 2 \\
\text { CTBP2 } \\
\text { ortholog }\end{array}$ & $\begin{array}{l}\text { C-TERMINAL-BINDING } \\
\text { PROTEIN } 2 \text { (PTHR46029:SF3) }\end{array}$ & transcription cofactor \\
\hline O00571 & DDX3X & $\begin{array}{l}\text { ATP-dependent RNA helicase } \\
\text { DDX3X } \\
\text { DDX3X } \\
\text { ortholog }\end{array}$ & $\begin{array}{l}\text { ATP-DEPENDENT RNA } \\
\text { HELICASE DDX3X } \\
\text { (PTHR47958:SF4) }\end{array}$ & - \\
\hline P15151 & PVR & $\begin{array}{l}\text { Poliovirus receptor } \\
\text { PVR } \\
\text { ortholog }\end{array}$ & $\begin{array}{l}\text { POLIOVIRUS RECEPTOR } \\
\text { (PTHR23277:SF109) }\end{array}$ & - \\
\hline P60568 & IL2 & $\begin{array}{l}\text { Interleukin-2 } \\
\text { IL2 } \\
\text { ortholog }\end{array}$ & e & - \\
\hline Q9H2X3 & CLEC4M & $\begin{array}{l}\text { C-type lectin domain family } 4 \\
\text { member M } \\
\text { CLEC4M } \\
\text { ortholog }\end{array}$ & $\begin{array}{l}\text { C-TYPE LECTIN DOMAIN } \\
\text { FAMILY } 4 \text { MEMBER M } \\
\text { (PTHR22802:SF197) }\end{array}$ & membrane traffic protein \\
\hline Q9NY25 & CLEC5A & $\begin{array}{l}\text { C-type lectin domain family } 5 \\
\text { member A } \\
\text { CLEC5A } \\
\text { ortholog }\end{array}$ & $\begin{array}{l}\text { C-TYPE LECTIN DOMAIN } \\
\text { FAMILY } 5 \text { MEMBER A } \\
\text { (PTHR47536:SF1) }\end{array}$ & - \\
\hline P05362 & ICAM1 & $\begin{array}{l}\text { Intercellular adhesion molecule } 1 \\
\text { ICAM1 } \\
\text { ortholog }\end{array}$ & $\begin{array}{l}\text { INTERCELLULAR ADHESION } \\
\text { MOLECULE } 1 \\
\text { (PTHR13771:SF9) }\end{array}$ & - \\
\hline Q92692 & NECTIN2 & Nectin-2 & NECTIN-2 (PTHR47387:SF1) & - \\
\hline
\end{tabular}




\begin{tabular}{|c|c|c|c|c|}
\hline & & $\begin{array}{l}\text { NECTIN2 } \\
\text { ortholog }\end{array}$ & & \\
\hline $\mathrm{P} 02751$ & FN1 & $\begin{array}{l}\text { Fibronectin } \\
\text { FN1 } \\
\text { ortholog }\end{array}$ & $\begin{array}{l}\text { FIBRONECTIN } \\
\text { (PTHR19143:SF267) }\end{array}$ & $\begin{array}{l}\text { intercellular signal } \\
\text { molecule }\end{array}$ \\
\hline Q12824 & $\begin{array}{l}\text { SMARCB } \\
1\end{array}$ & $\begin{array}{l}\text { SWI/SNF-related matrix- } \\
\text { associated actin-dependent } \\
\text { regulator of chromatin subfamily } \\
\text { B member } 1 \\
\text { SMARCB1 } \\
\text { ortholog }\end{array}$ & $\begin{array}{l}\text { SWI/SNF-RELATED MATRIX- } \\
\text { ASSOCIATED ACTIN- } \\
\text { DEPENDENT REGULATOR OF } \\
\text { CHROMATIN SUBFAMILY B } \\
\text { MEMBER } 1 \text { (PTHR10019:SF5) }\end{array}$ & DNA binding protein \\
\hline Q7Z6L0 & PRRT2 & $\begin{array}{l}\text { Proline-rich transmembrane } \\
\text { protein } 2 \\
\text { PRRT2 } \\
\text { ortholog }\end{array}$ & $\begin{array}{l}\text { PROLINE-RICH } \\
\text { TRANSMEMBRANE PROTEIN } \\
2 \text { (PTHR14948:SF20) }\end{array}$ & - \\
\hline P09341 & CXCL1 & $\begin{array}{l}\text { Growth-regulated alpha protein } \\
\text { CXCL1 } \\
\text { ortholog }\end{array}$ & $\begin{array}{l}\text { GROWTH-REGULATED } \\
\text { ALPHA PROTEIN } \\
\text { (PTHR10179:SF69) }\end{array}$ & chemokine \\
\hline P07202 & TPO & $\begin{array}{l}\text { Thyroid peroxidase } \\
\text { TPO } \\
\text { ortholog }\end{array}$ & $\begin{array}{l}\text { THYROID PEROXIDASE } \\
\text { (PTHR11475:SF60) }\end{array}$ & peroxidase \\
\hline $\mathrm{P} 01562$ & $\begin{array}{l}\text { IFNA13 } \\
\text { IFNA1 }\end{array}$ & $\begin{array}{l}\text { Interferon alpha-1/13 } \\
\text { IFNA13 } \\
\text { ortholog }\end{array}$ & $\begin{array}{l}\text { INTERFERON ALPHA-1/13 } \\
\text { (PTHR11691:SF64) }\end{array}$ & - \\
\hline Q14242 & SELPLG & $\begin{array}{l}\text { P-selectin glycoprotein ligand } 1 \\
\text { SELPLG } \\
\text { ortholog }\end{array}$ & $\begin{array}{l}\text { P-SELECTIN GLYCOPROTEIN } \\
\text { LIGAND } 1 \text { (PTHR17384:SF7) }\end{array}$ & - \\
\hline $\mathrm{P} 02724$ & GYPA & $\begin{array}{l}\text { Glycophorin-A } \\
\text { GYPA } \\
\text { ortholog }\end{array}$ & $\begin{array}{l}\text { GLYCOPHORIN-A } \\
\text { (PTHR13813:SF3) }\end{array}$ & - \\
\hline O00182 & LGALS9 & $\begin{array}{l}\text { Galectin-9 } \\
\text { LGALS9 } \\
\text { ortholog }\end{array}$ & $\begin{array}{l}\text { GALECTIN-9 } \\
\text { (PTHR11346:SF80) }\end{array}$ & $\begin{array}{l}\text { extracellular matrix } \\
\text { protein }\end{array}$ \\
\hline O60493 & SNX3 & $\begin{array}{l}\text { Sorting nexin-3 } \\
\text { SNX3 } \\
\text { ortholog }\end{array}$ & $\begin{array}{l}\text { SORTING NEXIN-3 } \\
\text { (PTHR45963:SF1) }\end{array}$ & - \\
\hline Q13049 & TRIM32 & $\begin{array}{l}\text { E3 ubiquitin-protein ligase } \\
\text { TRIM32 } \\
\text { TRIM32 } \\
\text { ortholog }\end{array}$ & $\begin{array}{l}\text { E3 UBIQUITIN-PROTEIN } \\
\text { LIGASE TRIM32 } \\
\text { (PTHR25464:SF3) }\end{array}$ & - \\
\hline P29508 & $\begin{array}{l}\text { SERPINB } \\
3\end{array}$ & $\begin{array}{l}\text { Serpin B3 } \\
\text { SERPINB3 } \\
\text { ortholog }\end{array}$ & SERPIN B3 (PTHR11461:SF320) & protease inhibitor \\
\hline P15529 & CD46 & $\begin{array}{l}\text { Membrane cofactor protein } \\
\text { CD46 } \\
\text { ortholog }\end{array}$ & $\begin{array}{l}\text { MEMBRANE COFACTOR } \\
\text { PROTEIN (PTHR19325:SF521) }\end{array}$ & - \\
\hline P06756 & ITGAV & $\begin{array}{l}\text { Integrin alpha-V } \\
\text { ITGAV } \\
\text { ortholog }\end{array}$ & $\begin{array}{l}\text { INTEGRIN ALPHA-V } \\
\text { (PTHR23220:SF4) }\end{array}$ & - \\
\hline Q13291 & SLAMF1 & $\begin{array}{l}\text { Signaling lymphocytic activation } \\
\text { molecule } \\
\text { SLAMF1 } \\
\text { ortholog }\end{array}$ & $\begin{array}{l}\text { SIGNALING LYMPHOCYTIC } \\
\text { ACTIVATION MOLECULE } \\
\text { (PTHR12080:SF49) }\end{array}$ & $\begin{array}{l}\text { immunoglobulin receptor } \\
\text { superfamily }\end{array}$ \\
\hline P55265 & ADAR & $\begin{array}{l}\text { Double-stranded RNA-specific } \\
\text { adenosine deaminase } \\
\text { ADAR } \\
\text { ortholog }\end{array}$ & $\begin{array}{l}\text { DOUBLE-STRANDED RNA- } \\
\text { SPECIFIC ADENOSINE } \\
\text { DEAMINASE } \\
\text { (PTHR10910:SF107) }\end{array}$ & RNA binding protein \\
\hline Q9UQV4 & LAMP3 & $\begin{array}{l}\text { Lysosome-associated membrane } \\
\text { glycoprotein } 3\end{array}$ & $\begin{array}{l}\text { LYSOSOME-ASSOCIATED } \\
\text { MEMBRANE GLYCOPROTEIN }\end{array}$ & $\begin{array}{l}\text { membrane trafficking } \\
\text { regulatory protein }\end{array}$ \\
\hline
\end{tabular}




\begin{tabular}{|c|c|c|c|c|}
\hline & & $\begin{array}{l}\text { LAMP3 } \\
\text { ortholog }\end{array}$ & 3 (PTHR11506:SF30) & \\
\hline Q9BZR9 & TRIM8 & $\begin{array}{l}\text { E3 ubiquitin-protein ligase } \\
\text { TRIM8 } \\
\text { TRIM8 } \\
\text { ortholog }\end{array}$ & $\begin{array}{l}\text { E3 UBIQUITIN-PROTEIN } \\
\text { LIGASE TRIM8 } \\
\text { (PTHR25465:SF19) }\end{array}$ & - \\
\hline C9JQL5 & C9JQL5 & $\begin{array}{l}\text { Putative dispanin subfamily A } \\
\text { member } 2 d \\
\text { unassigned } \\
\text { ortholog }\end{array}$ & $\begin{array}{l}\text { DISPANIN SUBFAMILY A } \\
\text { MEMBER 2D-RELATED } \\
\text { (PTHR13999:SF23) }\end{array}$ & - \\
\hline Q12794 & HYAL1 & $\begin{array}{l}\text { Hyaluronidase-1 } \\
\text { HYAL1 } \\
\text { ortholog }\end{array}$ & $\begin{array}{l}\text { HYALURONIDASE-1 } \\
\text { (PTHR11769:SF23) }\end{array}$ & glycosidase \\
\hline
\end{tabular}

Table 1 : The 279 enriched gene based on gene ontology (GO Slim) - Biological process selected based on criteria P-Value less than 0.05 


\begin{tabular}{|c|c|c|c|c|c|c|}
\hline \multirow[t]{27}{*}{2} & \multirow[t]{27}{*}{ TNF } & \multirow{27}{*}{$\begin{array}{l}\text { Fever, Pneumonia, } \\
\text { Heart Disease, } \\
\text { Kidney Disease, } \\
\text { Lung Disease, } \\
\text { Diabetes, } \\
\text { Hypertension, } \\
\text { Cancer, Sepsis, } \\
\text { Acute Kidney } \\
\text { Injury, } \\
\text { Neutrophilia, } \\
\text { Lymphophenia, } \\
\text { Thrombocytopenia, } \\
\text { Multiple Organ } \\
\text { Failure, SARS- } \\
\text { CoV, Viral Life } \\
\text { Cycle }\end{array}$} & \multirow{27}{*}{$\begin{array}{ll}\text { amrinone } & 0.800 \\
\text { anti-D } & 0.851 \\
\text { chloroquine } & 0.969 \\
\text { clenbuterol } & 0.819 \\
\text { gentamicin } & 0.400 \\
\text { lenalidomide } & 0.940 \\
\text { penicillin } & 0.933 \\
\text { pentoxifylline } & 0.990 \\
\text { pirfenidone } & 0.816 \\
\text { pomalidomide } & 0.800 \\
\text { sulphate } & 0.495 \\
\text { thalidomide } & 0.980 \\
\text { timolol } & 0.647 \\
\end{array}$} & \multirow{3}{*}{$\begin{array}{l}\text { Drug } \\
\text { Infliximab }\end{array}$} & \multirow{3}{*}{$\begin{array}{l}\text { Interaction } \\
\text { Type } \\
\text { antibody, } \\
\text { inhibitor }\end{array}$} & \multirow[t]{2}{*}{ Score } \\
\hline & & & & & & \\
\hline & & & & & & 17 \\
\hline & & & & \multirow[t]{2}{*}{ Adalimumab } & \multirow[t]{2}{*}{$\begin{array}{l}\text { antibody, } \\
\text { inhibitor }\end{array}$} & 12 \\
\hline & & & & & & \\
\hline & & & & Etanercept & $\begin{array}{l}\text { antibody, } \\
\text { inhibitor }\end{array}$ & 12 \\
\hline & & & & Thalidomide & inhibitor & 11 \\
\hline & & & & Chloroquine & $\mathrm{n} / \mathrm{a}$ & 6 \\
\hline & & & & \multirow[t]{2}{*}{ Certolizumab pegol } & \multirow{2}{*}{$\begin{array}{l}\text { neutralizer, } \\
\text { antibody, } \\
\text { inhibitor }\end{array}$} & 6 \\
\hline & & & & & & \\
\hline & & & & Inamrinone & inhibitor & 6 \\
\hline & & & & Clenbuterol & $\mathrm{n} / \mathrm{a}$ & 6 \\
\hline & & & & Golimumab & $\begin{array}{l}\text { antibody, } \\
\text { inhibitor }\end{array}$ & 6 \\
\hline & & & & Glucosamine & $\mathrm{n} / \mathrm{a}$ & 6 \\
\hline & & & & Risperidone & $\mathrm{n} / \mathrm{a}$ & 3 \\
\hline & & & & Carbamazepine & $\mathrm{n} / \mathrm{a}$ & 3 \\
\hline & & & & Cefotaxime & $\mathrm{n} / \mathrm{a}$ & 3 \\
\hline & & & & Folic acid & $\mathrm{n} / \mathrm{a}$ & 2 \\
\hline & & & & Rabeprazole & $\mathrm{n} / \mathrm{a}$ & 2 \\
\hline & & & & Timolol maleate & $\mathrm{n} / \mathrm{a}$ & 2 \\
\hline & & & & Pomalidomide & inhibitor & 2 \\
\hline & & & & Penicillin g sodium & $\mathrm{n} / \mathrm{a}$ & 2 \\
\hline & & & & Omeprazole & $\mathrm{n} / \mathrm{a}$ & 2 \\
\hline & & & & Didanosine & $\mathrm{n} / \mathrm{a}$ & 2 \\
\hline & & & & Midazolam & $\mathrm{n} / \mathrm{a}$ & 2 \\
\hline & & & & Miltefosine & $\mathrm{n} / \mathrm{a}$ & 2 \\
\hline & & & & Methimazole & $\mathrm{n} / \mathrm{a}$ & 2 \\
\hline
\end{tabular}




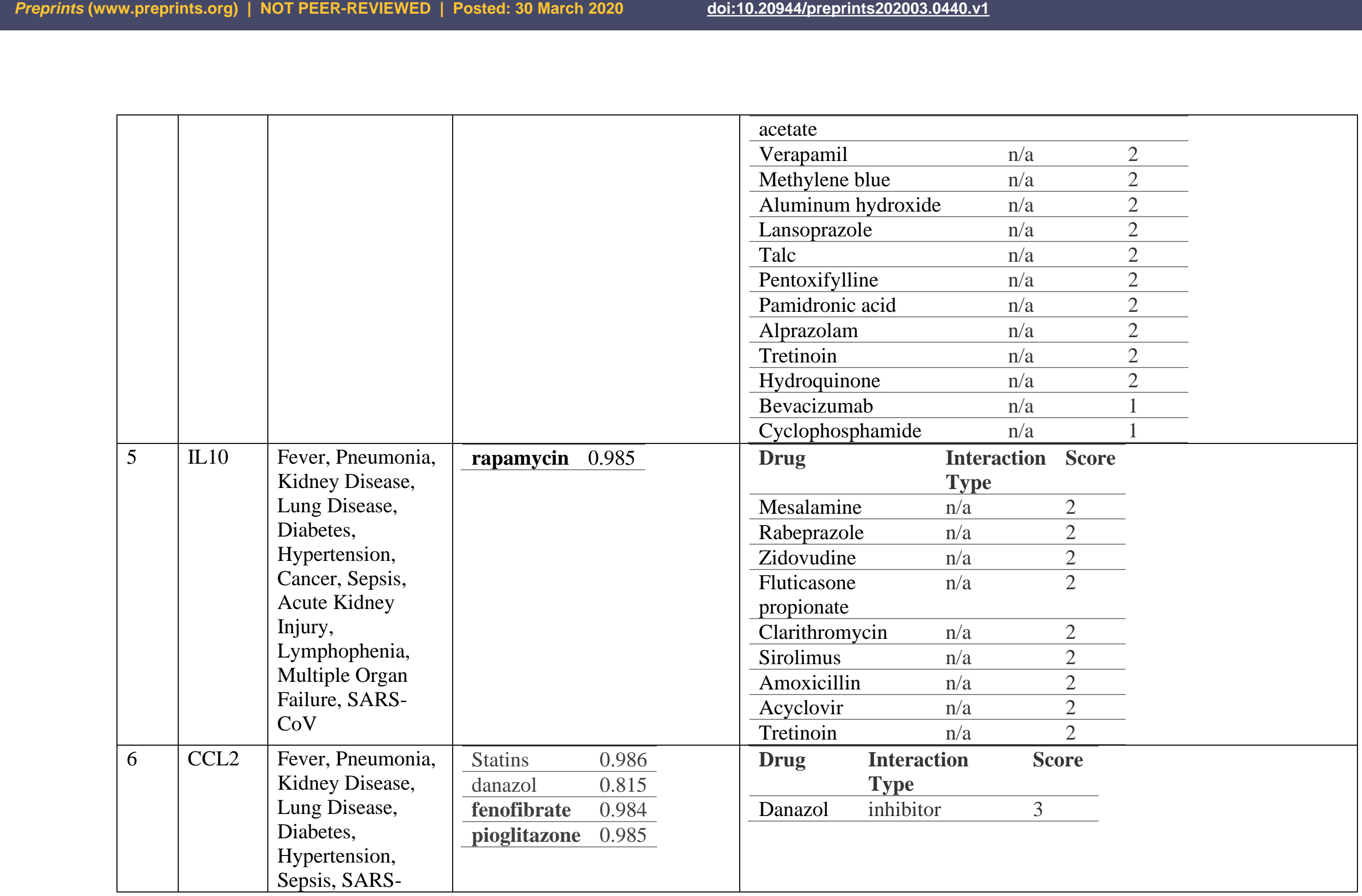




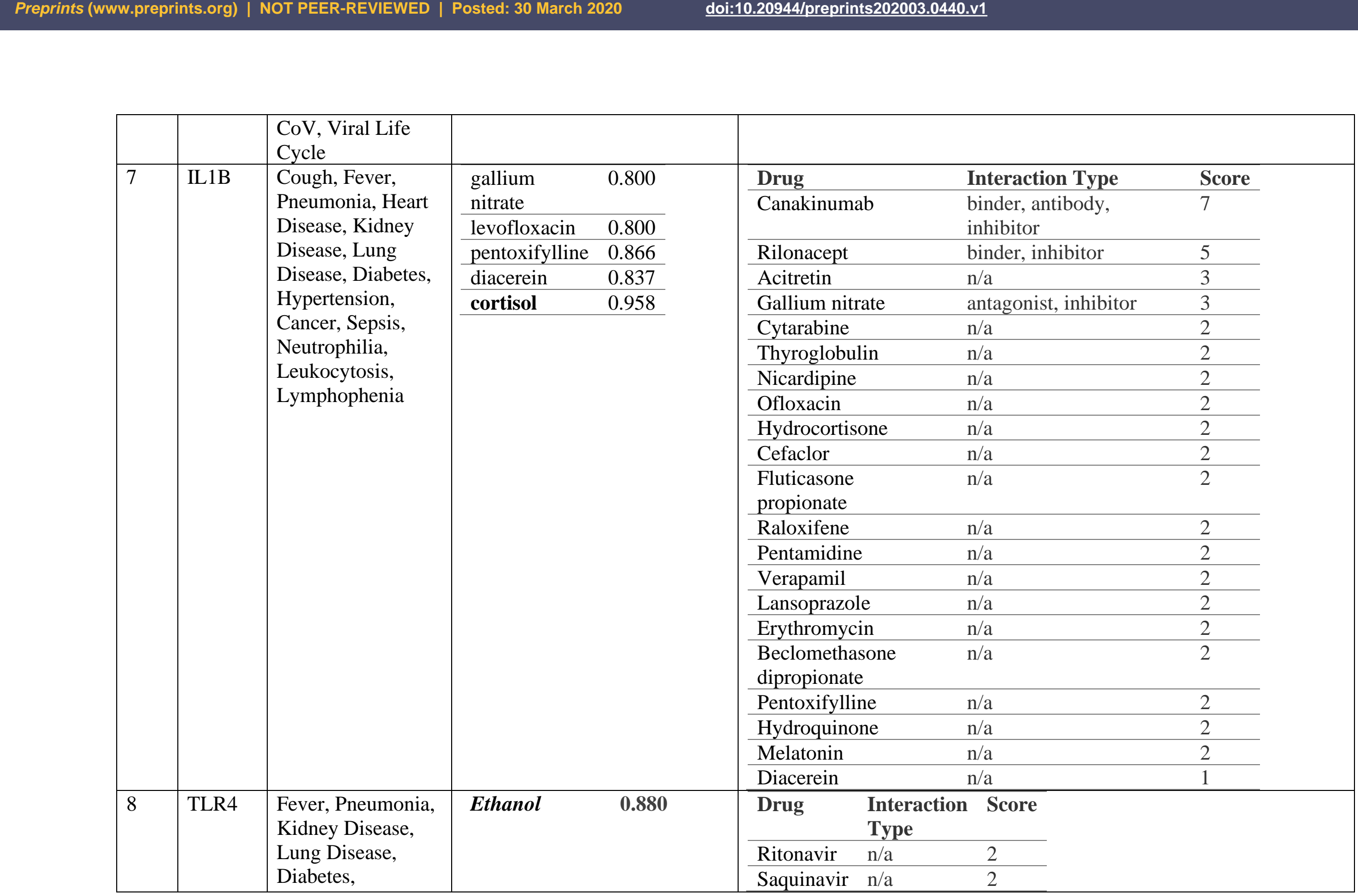




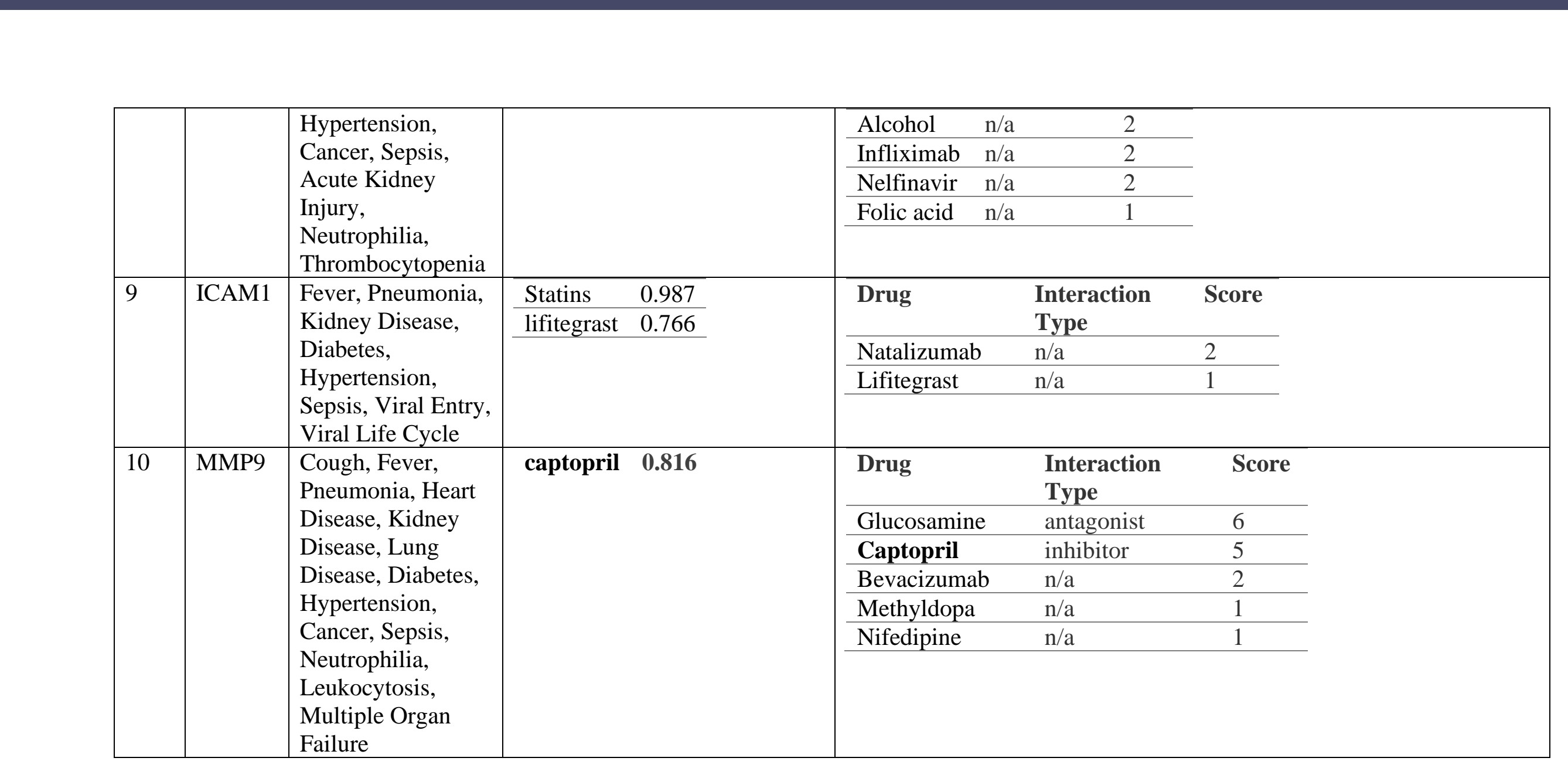

Table 2: Identified top 10 druggable genes, showing gene-disease association and predicted of STITCH \&DGIdb2.0 of FDA drugs from druggene association

Failure

\section{.}




\begin{tabular}{|c|c|c|c|c|c|c|c|c|c|c|c|c|}
\hline Hypertension & $\begin{array}{l}\text { STITCH } \\
\text { Drug } \\
\text { prediction }\end{array}$ & Diabetes & $\begin{array}{l}\text { STITCH Drug } \\
\text { prediction }\end{array}$ & $\begin{array}{l}\text { Heart } \\
\text { Disease }\end{array}$ & $\begin{array}{l}\text { STITCH } \\
\text { Drug } \\
\text { prediction }\end{array}$ & $\begin{array}{l}\text { Lung } \\
\text { Disease }\end{array}$ & $\begin{array}{l}\text { STITCH } \\
\text { Drug } \\
\text { prediction }\end{array}$ & $\begin{array}{l}\text { Kidney } \\
\text { Disease }\end{array}$ & $\begin{array}{l}\text { STITCH } \\
\text { Drug } \\
\text { prediction }\end{array}$ & Cancer & $\begin{array}{l}\text { STITCH Drug } \\
\text { prediction }\end{array}$ & Asymptomatic \\
\hline $\begin{array}{l}\text { VEGFA } \\
\text { IL6 } \\
\text { TNF } \\
\text { CCL2 } \\
\text { MMP9 } \\
\text { ALB } \\
\text { IL10 } \\
\text { PTGS2 } \\
\text { CXCL8 } \\
\text { CASP3 }\end{array}$ & $\begin{array}{l}\text { CASP3 } \\
\text { paclitaxel } \\
(0.972) \\
\text { retinoic acid } \\
(0.961) \\
\text { thalidomide } \\
(0.945) \\
\text { IL10, } \\
\text { VEGFA } \\
\text { aspirin } \\
(0.954) \\
\text { rapamycin } \\
(0.985) \\
\text { retinoic acid } \\
(0.961)\end{array}$ & $\begin{array}{l}\text { IL6 } \\
\text { TNF } \\
\text { CXCL8 } \\
\text { IL10 } \\
\text { CCL2 } \\
\text { ICAM1 } \\
\text { IFNG } \\
\text { IL2 } \\
\text { FN1 } \\
\text { CXCR4 }\end{array}$ & $\begin{array}{l}\text { CXCL12 } \\
\text { Plerixafor } 0.964 \\
\text { Quinine } 0.915 \\
\text { IFNG } \\
\text { pentoxifylline } \\
0.914 \\
\text { IL10 } \\
\text { aspirin } 0.954 \\
\text { methylpredniso } \\
0.930 \\
\text { Pentoxiflline } \\
0.924 \\
\text { rapamycin } \\
0.985 \\
\text { retonic acid } \\
0.961\end{array}$ & $\begin{array}{l}\text { IL6 } \\
\text { TNF } \\
\text { CXCL8 } \\
\text { CCL2 } \\
\text { MAPK1 } \\
\text { EGFR } \\
\text { ICAM1 } \\
\text { CCL5 } \\
\text { CXCR4 } \\
\text { AGT }\end{array}$ & $\begin{array}{l}\text { CXCR4 } \\
\text { plerixafor } \\
0.999 \\
\text { EGFR } \\
\text { afatinib } \\
0.999 \\
\text { eriotinib } \\
0.999 \\
\text { gefitinib } \\
0.999 \\
\text { lapatinib } \\
0.999 \\
\text { paclitaxel } \\
0.982 \\
\text { IL6 } \\
\text { Cortisol } \\
0.976\end{array}$ & $\begin{array}{l}\text { IL6 } \\
\text { TNF } \\
\text { CXCL8 } \\
\text { IFNG } \\
\text { CCL5 } \\
\text { IL10 } \\
\text { CCL2 } \\
\text { ICAM1 } \\
\text { CXCL1 } \\
\text { CXCR4 }\end{array}$ & $\begin{array}{l}\text { CXCL12 } \\
\text { Plerixafor } \\
0.964\end{array}$ & $\begin{array}{l}\text { IL6 } \\
\text { TNF } \\
\text { CXCL8 } \\
\text { CCL2 } \\
\text { IL10 } \\
\text { ICAM1 } \\
\text { CCL5 } \\
\text { FN1 } \\
\text { EGFR } \\
\text { CXCR4 }\end{array}$ & $\begin{array}{l}\text { CXCR4 } \\
\text { plerixafor } \\
0.999 \\
\text { EGFR } \\
\text { afatinib } 0.999 \\
\text { bosutinib } \\
0.909 \\
\text { erlotinib } \\
0.999 \\
\text { lapatinib } \\
0.981 \\
\text { vendetanib } \\
0.998 \\
\text { IL6 } \\
\text { pentoxifylline } \\
0.948 \\
\text { retinoic acid } \\
0.968\end{array}$ & $\begin{array}{l}\text { VEGFA } \\
\text { STAT3 } \\
\text { IL6 } \\
\text { TNF } \\
\text { MAPK3 } \\
\text { MAPK1 } \\
\text { CASP3 } \\
\text { MMP9 } \\
\text { PTGS } \\
\text { EGF }\end{array}$ & $\begin{array}{l}\text { CASP3 } \\
\text { gentamicin } 0.958 \\
\text { hydroxychloroquine } \\
0.942 \\
\text { sorafenib } 0.948 \\
\text { sulindac } 0.925 \\
\text { thalidomide } 0.45 \\
\text { EGFR } \\
\text { erlotinib } 0.999 \\
\text { vandetanib } 0.998\end{array}$ & $\begin{array}{l}\text { IL6 } \\
\text { TNF } \\
\text { CXCL8 } \\
\text { IL1B } \\
\text { IL10 } \\
\text { CCL2 } \\
\text { ICAM1 } \\
\text { IL2 } \\
\text { STAT3 } \\
\text { CCL5 }\end{array}$ \\
\hline
\end{tabular}

Table 3: Top 10 key genes of high risk with predicted FDA approved drug and asymptomatic group identified from Protein-Protein interaction network by using Cytohubba 